
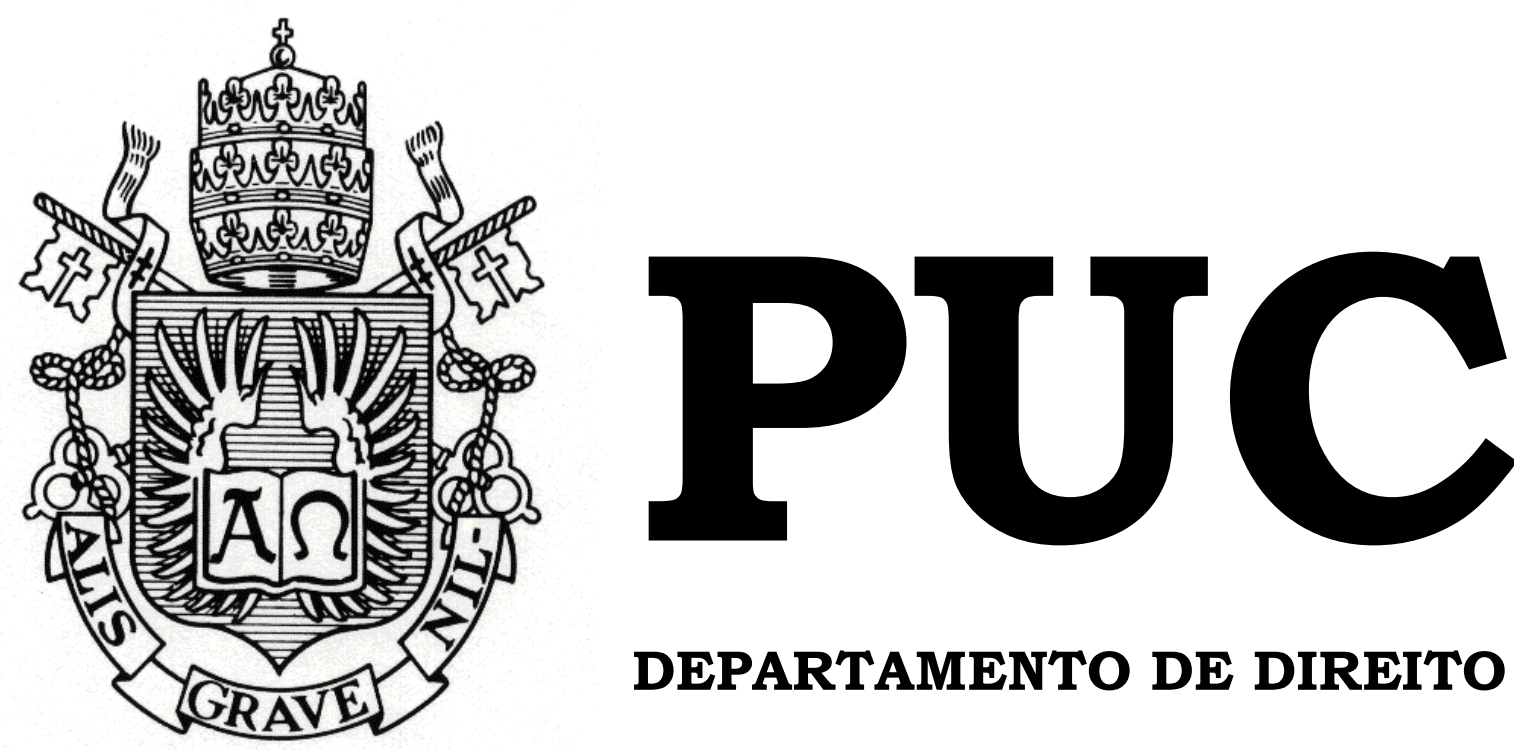

DEPARTAMENTO DE DIREITO

\title{
ALIMENTOS GRAVÍDICOS: ASPECTOS MATERIAIS E PROCESSUAIS DA LEI $\mathbf{N}^{\circ}$ $11.804 / 2008$
}

por

JOANA VARGAS SAMPAIO DOS SANTOS

ORIENTADOR(A): Kátia Regina da Costa Silva

2011.1

PONTIFÍCIA UNIVERSIDADE CATÓLICA DO RIO DE JANEIRO

RUA MARQUÊS DE SÃO VICENTE, 225 - CEP 22453-900

RIO DE JANEIRO - BRASIL 


\section{ALIMENTOS GRAVÍDICOS: ASPECTOS MATERIAIS E PROCESSUAIS DA LEI $\mathbf{N}^{\circ}$ $11.804 / 2008$}

por

JOANA VARGAS SAMPAIO DOS SANTOS

Monografia apresentada ao Departamento de Direito da Pontificia Universidade Católica do Rio de Janeiro (PUC-RIO) como requisito parcial para a obtenção do Título de Bacharel em Direito.

Orientador(a): Kátia Regina da Costa Silva 


\section{RESUMO}

O trabalho, conforme o próprio nome indica, se propõe a discorrer sobre a lei de alimentos gravídicos (Lei 11.804/2008).

Inicialmente, é feita uma abordagem sobre os alimentos em seus aspectos gerais. A idéia seria permitir, a partir disso, uma melhor visualização das peculiaridades da lei de alimentos e o que teria em comum com os alimentos em geral.

A partir do segundo capítulo, serão desenvolvidos os aspectos materiais da lei. Para tanto, serão explanadas as teorias da personalidade civil e como isso influenciou diretamente na questão da concessão dos alimentos ao nascituro. $\mathrm{O}$ direito a vida será abordado. Ainda, será realizado um breve histórico para demonstrar como a lei de alimentos gravídicos alterou a jurisprudência dominante acerca do tema.

No terceiro e último capítulo, serão apresentadas as questões processuais da lei tais como legitimidade, quantum devido, ônus da prova e indícios de paternidade, possibilidade de tutela antecipada, limites da coisa julgada, citação e termo inicial, competência e o veto do art. $3^{\circ}$ da lei, o rito a ser seguido, a ação revisional e de exoneração, possibilidade de aplicação da lei em ação ajuizada antes do advento da lei de alimentos gravídicos e a responsabilidade da genitora cumulada com o veto do art.10 da Lei 11.804/2008.

Palavras-chave: Direito a Alimentos. Direito à vida. Alimentos ao nascituro. Binômio possibilidade-necessidade. Indícios de paternidade. Teorias da Personalidade

Civil. 


\section{SUMÁRIO}

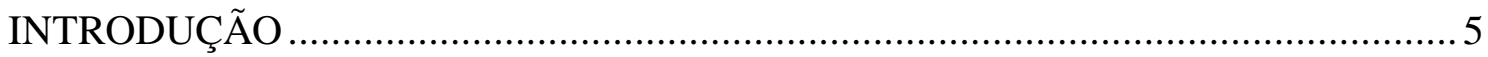

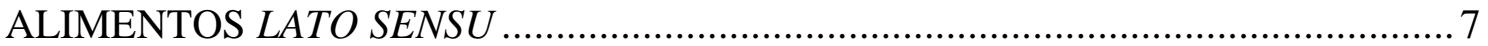

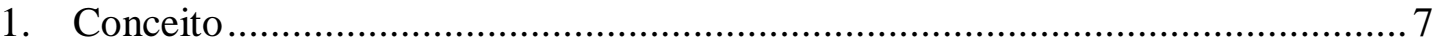

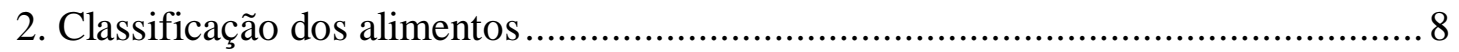

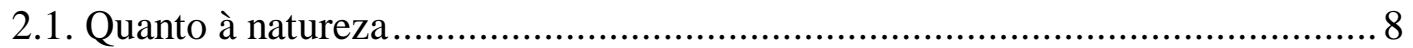

2.1.1. Alimentos Naturais (ou necessários) ……………………………………. 8

2.1.2. Alimentos Civis (ou côngruos) ………………………………………...... 9

2.2. Quanto à causa jurídica (fonte da obrigação alimentar) ................................... 9

2.2.1. Alimentos Legítimos ......................................................................... 9

2.2.2. Alimentos Voluntários .......................................................................... 9

2.2.3. Alimentos indenizatórios ou Ressarcitórios............................................... 9

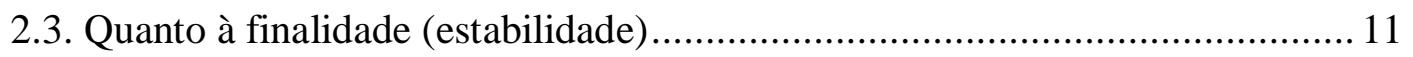

2.3.1. Alimentos Definitivos (ou regulares) ......................................................... 11

2.3.2. Alimentos Provisórios .......................................................................... 11

2.3.3. Alimentos Provisionais ou ad litem ............................................................ 11

2.4. Quanto ao momento em que são reclamados.................................................. 14

2.4.1. Alimentos Futuros ............................................................................. 14

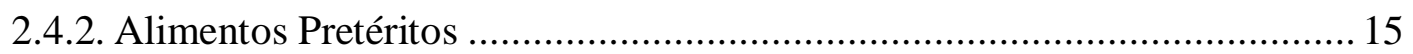

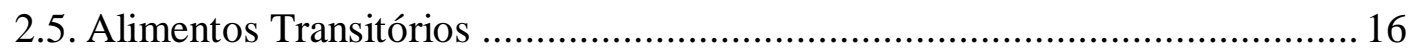

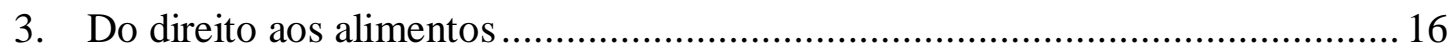

3.1. Obrigação de Prestar alimentos versus dever familiar............................... 16

3.2. Características da obrigação ............................................................... 19

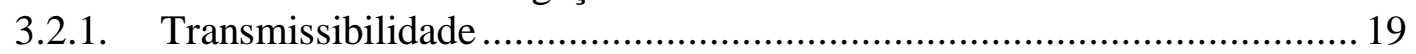

3.2.2. Divisibilidade .......................................................................... 21

3.2.3. Condicionalidade ......................................................................... 21

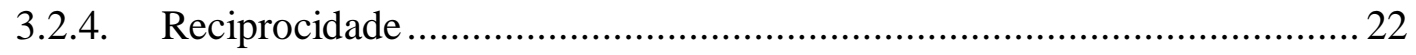

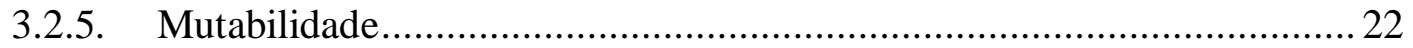

3.3. Características do direito aos alimentos................................................. 23

3.3.1. Personalíssimo .................................................................................. 23

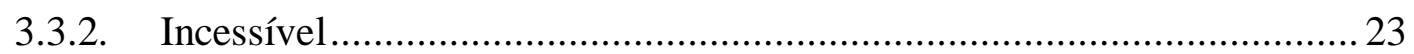

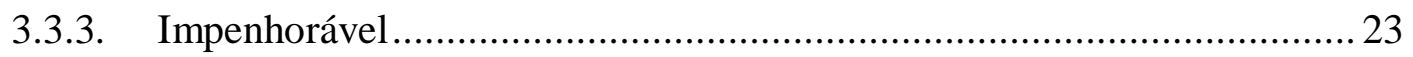

3.3.4. Incompensável ........................................................................... 24

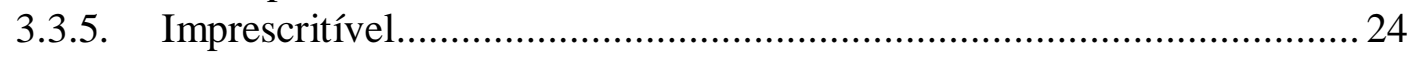

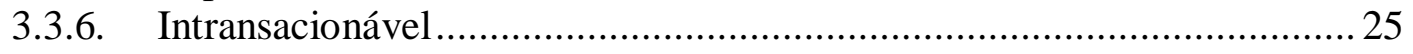

3.3.7. Irrepetível ou irrestituível................................................................. 25

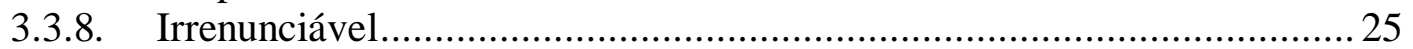

3.4. Pressupostos da Obrigação Alimentar (Arts. 1964 \$1 $1^{\circ}$ e 1965 CC/02) .... 26

3.4.1. Existência de um vínculo de parentesco ............................................... 26

3.4.2. Necessidade do reclamante ………………...................................... 26

3.4.3. Possibilidade da Pessoa Obrigada ………………................................ 27

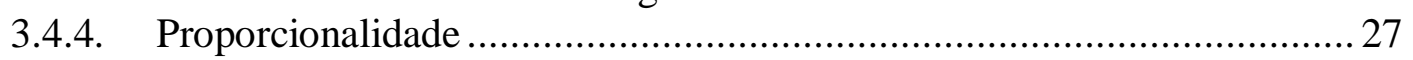

3.5. Pressupostos subjetivos ................................................................... 28

3.5.1. Quem deve alimentos..................................................................... 28

3.5.2. Quem pode pleitear alimentos ............................................................... 34

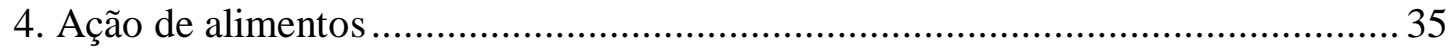

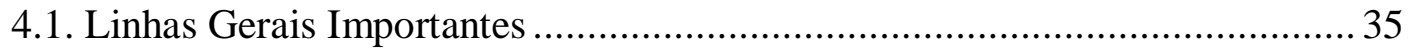

4.2. Ação de Alimentos pelo Rito Especial .......................................................... 36

4.2.1. Alimentos Provisórios ............................................................................... 36 


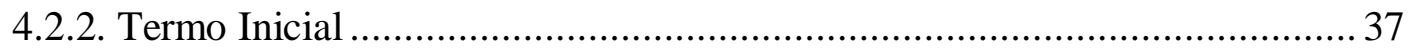

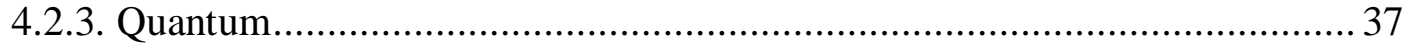

4.3. Ação de Alimentos pelo Rito Ordinário ........................................................ 38

4.3.1. Alimentos Provisionais .............................................................................. 38

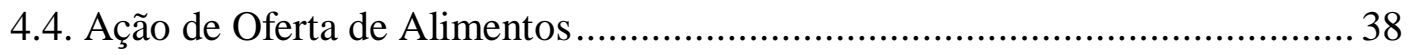

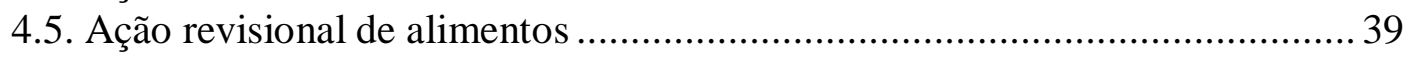

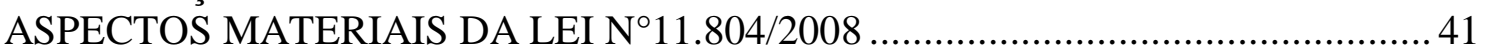

1. Personalidade Civil e Direitos da Personalidade .............................................. 41

1.1. Personalidade e Pessoa Natural .............................................................. 41

1.2. Começo da Personalidade .................................................................... 42

1.2.1. Teorias sobre a personalidade civil (até a consagração dos direitos do nascituro pela L.11.804/2008) .................................................................. 42

1.2.2. Sistema de Proteção ao nascituro: direitos do nascituro .......................... 47

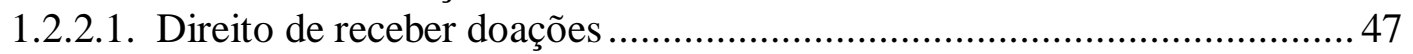

1.2.2.2. Reconhecimento voluntário de filiação ............................................. 47

1.2.2.3. Direito a curatela e representação..................................................... 47

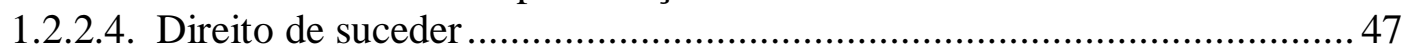

1.2.2.5. Proteção do Nascituro através da penalização do aborto ......................... 47

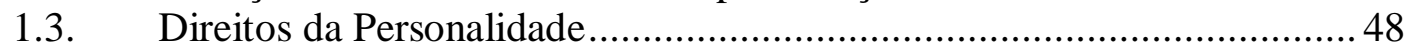

1.3.1. Direito à vida e a integridade física .................................................. 48

2. Alimentos Gravídicos - Histórico. Evolução Legislativa e Jurisprudencial. ...... 49

3. Algumas considerações quanto à classificação dos alimentos gravídicos ..............54

4. Pressupostos para concessão de alimentos gravídicos (art. $2^{\circ}$, parágrafo único e

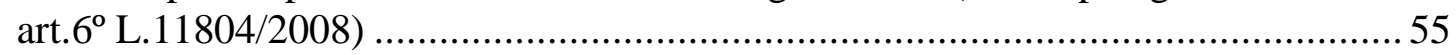

5. Conversão dos Alimentos Gravídicos em Pensão Alimentícia ............................. 55

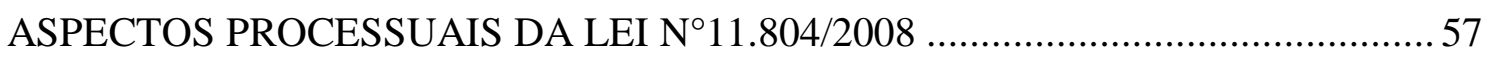

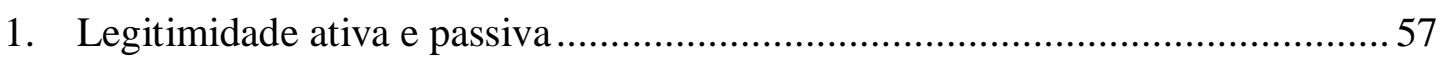

1.1. Legitimidade Ativa (art. $1^{\circ}$ e art. $6^{\circ}$, parágrafo único L.11.804/2008) ............57

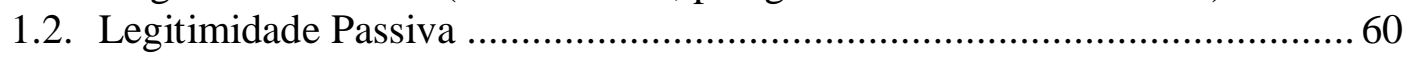

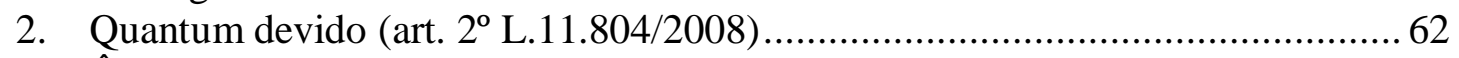

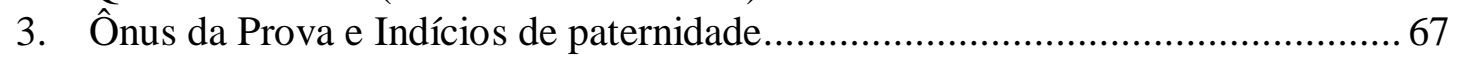

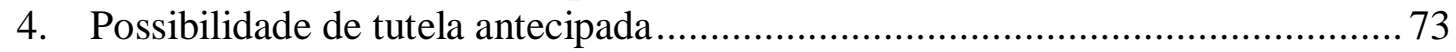

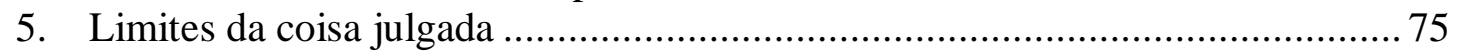

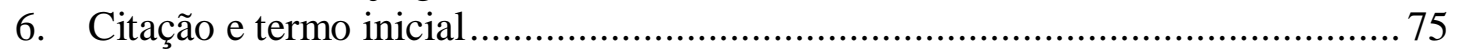

7. Competência e o veto do art. $3^{\circ}$ da Lei 11804/2008 ............................................ 77

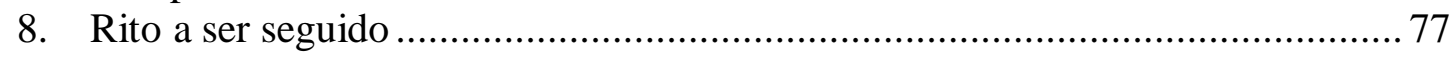

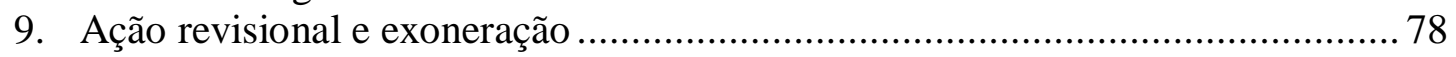

10. Possibilidade de aplicação da Lei 11.804/2008 em ação ajuizada anteriormente a referida lei............................................................................................. 78

11. Responsabilização da parte autora e veto do art.10 ...................................... 79

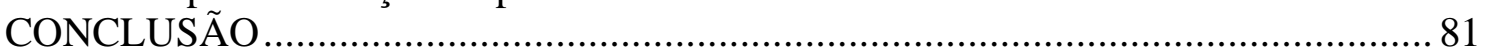

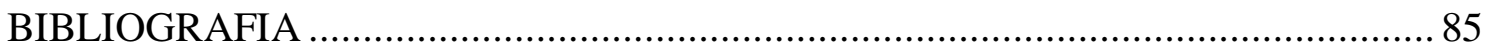

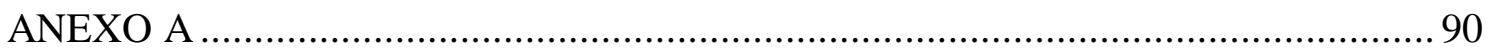

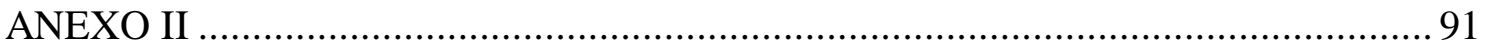




\section{INTRODUÇÃO}

O trabalho a ser apresentando, conforme o próprio nome indica, se propõe a comentar alguns aspectos materiais e processuais da lei de alimentos gravídicos (Lei 11.804/2008).

Alimentos gravídicos compreendem aqueles valores suficientes para cobrir as despesas adicionais do período de gravidez e que sejam delas decorrentes, da concepção ao parto (art.2 ${ }^{\circ}$ Lei 11.804/2008). Tais alimentos possuem grande importância porque é através deles que o direito à vida é garantido ao nascituro.

Apesar dos direitos do nascituro estarem resguardados no Código Civil $\left(\operatorname{art} .2^{\circ}\right)$, durante muito tempo foi negado a este o direito de pleitear em juízo alimentos para essa função. O fundamento utilizado para negar tal concessão era a falta de previsão legal.

O Código Civil somente reconhece personalidade após o nascimento com vida, antes haveria mera expectativa de direitos. Por isso, não sendo o nascituro sequer sujeito de direitos, estaria impossibilitado de figurar no pólo passivo da ação de alimentos.

No mais, a lei de alimentos (L. 5478/68) exige a comprovação do vínculo de parentesco para deferi-los. Para isso, deveria ser realizado exame de DNA por meio de líquido amniótico. Tal exame, porém, põe em risco a própria vida que se pretende resguardar.

Em outros termos, devido à falta de previsão legal, predominava na jurisprudência a impossibilidade do pleito alimentar pelo nascituro. Excepcionalmente, poderia o nascituro receber alimentos por via indireta através da mãe. Por exemplo, quando a mãe tinha direito a receber alimentos, acabava transmitindo a seu filho de forma indireta já que este estava dentro dela.

Doutrinadores sustentavam a incongruência dessa negativa dos alimentos tendo em vista que o próprio Código Civil, apesar de não reconhecer a personalidade, punha a salvo os direitos do nascituro. Alegavam 
que se tais direitos são postos a salvo, o direito a vida, do qual decorrem todos os demais, deveria ser considerado neste rol.

Com o advento da lei 11.804/2008, a discussão acerca do cabimento de alimentos ao nascituro foi sepultada. Os alimentos são devidos e agora há suporte legal.

Em que pese à importância da lei, vários dispositivos foram vetados por conterem equívocos. Outros dispositivos que se mantiveram merecem ser comentados ou mesmo analisados no caso concreto para compreender como a jurisprudência tem se posicionado.

Assim, o método utilizado neste trabalho foi dividido em três etapas, a saber: estudo dos alimentos em geral e as premissas de sua concessão; estudo dos aspectos materiais da lei de alimentos gravídicos para discutir as teorias da personalidade e os direitos do nascituro com ênfase ao direito à vida, incluindo o histórico do direito aos alimentos devidos ao nascituro; e, por fim, adentrar nos aspectos processuais da lei para tratar da questão da legitimidade, do quantum devido, do ônus da prova e dos indícios de paternidade, da possibilidade de tutela antecipada, dos limites da coisa julgada, da citação e do termo inicial, da competência e do veto do art. $3^{\circ}$ da lei 11.804/2008, do rito a ser seguido e da ação revisional e de exoneração, da possibilidade de aplicação da lei 11.804/2008 para ações ajuizadas antes do advento desta e a questão da responsabilização da genitora tendo em vista o veto do art.10 da lei.

Quanto aos procedimentos utilizados para o desenvolvimento do trabalho, as duas primeiras etapas foram desenvolvidas praticamente com base na doutrina (livros, artigos) e a última parte (aspectos processuais da lei) teve foco tanto na doutrina quanto na jurisprudência. Nessa última etapa, a jurisprudência foi essencial para definir o que se entende por indícios de paternidade e qual o posicionamento que tem sido adotado quanto à possibilidade de tutela antecipada.

Dito isto, o objetivo desse trabalho é esclarecer a própria lei 11.804/2008 em seus principais aspectos. 


\section{ALIMENTOS LATO SENSU}

\section{Conceito}

É certo que os alimentos são indispensáveis para a manutenção da vida. Todavia, para o direito, o termo "alimentos" possui uma acepção muito mais ampla do que puramente o direito à vida. $\mathrm{O}$ direito a alimentos está ligado à própria dignidade da pessoa humana. Por isso, não basta resguardar a vida, é preciso garantir uma vida digna.

Dito isto, o primeiro ponto a ser ressaltado é que a prestação alimentícia deve abranger, além dos alimentos propriamente ditos, indispensáveis à manutenção da vida, o sustento, a habitação, o vestuário, a saúde, a educação dos menores, lazer, dentre outras necessidades relativas ao desenvolvimento completo do indivíduo. Nesse sentido, estão os arts. 1694 e 1920 do CC/02.

Deste modo, ensina Carlos Roberto Gonçalves:

“O vocábulo 'alimentos' tem, todavia, uma conotação muito mais ampla que na linguagem comum, não se limitando ao necessário para o sustento de uma pessoa. Nele se compreende não só a obrigação de prestá-los, como também o conteúdo da obrigação a ser prestada. A aludida expressão tem, no campo do direito, uma acepção técnica de larga abrangência, compreendendo não só o indispensável ao sustento, como também o necessário a manutenção da condição social e moral do alimentando." 1

Outro ponto a ser analisado consiste no "cunho assistencial e não indenizatório" 2 da obrigação alimentar. Explique-se:

O art. $6^{\circ}$ da CRFB diz que "são direitos sociais a educação, a saúde, o trabalho, a moradia, o lazer, a segurança, a previdência social, a proteção à maternidade e à infância, a assistência aos desamparados, na forma desta constituição".

Portanto, há um dever do Estado em promover a assistência aos desamparados, compreendendo-se como tais aqueles que não podem prover por si mesmo tais direitos.

Ainda, conforme preleciona Caio Mario da Silva Pereira:

\footnotetext{
${ }^{1}$ GONÇALVES, Carlos Roberto. Direito Civil Brasileiro: Direito de Família, v. 6. $6^{\text {a }}$ ed. rev. e atual. São Paulo: Saraiva, 2009. p.455.

${ }^{2}$ Ibid. p 456
} 
"Todo indivíduo tem direito a subsistência. (...) Quem não pode prover sua subsistência, nem por isso é deixado a própria sorte. A sociedade há de propiciar-lhe sobrevivência, através de meios e órgãos estatais ou entidades particulares." ${ }^{3}$

Nessa esteira de raciocínio, Carlos Roberto Gonçalves ressalta o caráter de ordem pública contido nas normas relativas à prestação alimentar. Observe:

“o Estado tem interesse direto no cumprimento das normas que impõem a obrigação legal de alimentos, pois a inobservância ao seu comando aumenta o número de pessoas carentes e desprotegidas que devem, em conseqüência, serem por ele amparadas. Daí a razão por que as aludidas normas são consideradas de ordem pública, inderrogáveis por convenção entre os particulares e impostas por meio de violenta sanção, como a pena de prisão a que está sujeito o infrator". ${ }^{4}$

Em outros termos, a severidade com a qual se trata o inadimplemento de obrigações alimentares tem razão de ser justamente porque, na falta de cumprimento das prestações pelo particular obrigado (CC/02, art.1694, art.1696 e art.1697), esse dever recai sobre o Estado.

Em síntese, é possível dizer que a prestação de alimentos consiste em uma obrigação de cunho assistencial cuja finalidade é proporcionar àqueles que não podem garantir sua própria subsistência, condições de vida digna. Deve-se entender por condições de vida digna uma vida compatível com os padrões sociais.

Algumas das principais palavras-chaves ligadas à idéia de alimentos seriam: direito à vida, principio da solidariedade, binômio possibilidadenecessidade. Todas essas palavras-chaves serão devidamente explanadas ao longo do presente trabalho.

\section{Classificação dos alimentos}

\subsection{Quanto à natureza}

\subsubsection{Alimentos Naturais (ou necessários)}

Alimentos naturais resultam de culpa e podem ser definidos como sendo aqueles indispensáveis a satisfação das necessidades primárias da vida. Nesse sentido, estão os artigos $1694, \$ 2^{\circ}$ e art. 1704 par. único, ambos do CC/02. ${ }^{5}$

Freddie Didier Jr. define:

\footnotetext{
${ }^{3}$ PEREIRA, Caio Mario da Silva. Instituições de direito Civil: Direito de Família, v.5. 16 ${ }^{\mathrm{a}}$ ed. rev. e atual. - Rio de Janeiro: Forense, 2007. p. 495.

${ }^{4}$ GONÇALVES, Carlos Roberto. Op. Cit., p.456

${ }^{5}$ GONÇALVES, Carlos Roberto. Op. Cit. p. 457
} 
"os alimentos naturais são aqueles que compreendem o indispensável à satisfação das necessidades mais basilares e vitais do ser humano (necessarium vitae). É o imprescindível para sua subsistência." 6

\subsubsection{Alimentos Civis (ou côngruos)}

Destinam-se a manter a condição social, status familiar. Respaldo no art. 1694 , caput e $\$ 1^{\circ} \mathrm{CC} / 02 .^{7}$

Nas palavras de Freddie Didier Jr.:

"os alimentos civis (ou côngruos) vão além das necessidades básicas do indivíduo, para abranger também suas necessidades morais e intelectuais (necessarium personae). Por isso, são avaliados de acordo com as posses do devedor e a condição social do credor". ${ }^{8}$

\subsection{Quanto à causa jurídica (fonte da obrigação alimentar)}

\subsubsection{Alimentos Legítimos}

Devidos em virtude de uma obrigação legal que pode decorrer do parentesco, casamento ou companheirismo (CC, art.1694; Lei Federal n. 9.278, $\left.\operatorname{art.} 7^{\circ}\right)$

\subsubsection{Alimentos Voluntários}

Pode ocorrer por uma declaração de vontade inter vivos (ex.: obrigação assumida contratualmente por quem não tinha a obrigação de pagar alimentos), ou mortis causa, manifestada em testamento (ex.: mediante legado de alimentos, CC, art.1.920). Os alimentos voluntários que decorrem de ato inter vivos também são chamados de obrigacionais; os que decorrem de causa mortis, são chamados de testamentários.

\subsubsection{Alimentos indenizatórios ou Ressarcitórios}

Resultam da prática de um ato ilícito e constituem forma de indenização do dano (CC, arts. 948, II e 950). Por isso, assevera Freddie Didier Jr:

"não seriam alimentos propriamente ditos (daí falar-se em "alimentos impróprios"); seriam equiparados à prestação alimentar para fins de cálculo da indenização e determinação de seus beneficiários." 9

\footnotetext{
${ }^{6}$ DIDIER JR., Fredie; CUNHA, Leonardo José Carneiro da; BRAGA, Paula Sarno; OLIVEIRA, Rafael. Curso de direito Processual Civil: Execução. vol. 5. $2^{\mathrm{a}}$ ed., Jus Podivm, 2010. p. 692

${ }^{7}$ GONÇALVES, Carlos Roberto. Op. Cit., p.457

8 DIDIER JR., Fredie; CUNHA, Leonardo José Carneiro da; BRAGA, Paula Sarno; OLIVEIRA, Rafael. Op. Cit.. 692
} 
Por serem alimentos impróprios, algumas ponderações devem ser feitas:

a) não cabe prisão civil pelo não pagamento de dívida de alimentos quando estes forem do tipo indenizatório. Nesse sentido, Carlos Roberto Gonçalves:

"Somente os alimentos legais ou legítimos pertencem ao direito de família. Assim, a prisão civil pelo não pagamento de dívida de alimentos permitida na $\mathrm{CF} / 88$ (art. $5^{\circ}$, LXVII), somente poderá ser decretada no caso dos alimentos previstos nos arts. 1566, III e 1.694 e s. do Código Civil, que constituem relação de direito de família, sendo inadmissível em caso de não pagamento dos alimentos indenizatórios (responsabilidade civil ex delito) e dos voluntários (obrigacionais ou testamentários). (...)

Somente se admite como meio coercitivo para o adimplemento de pensão decorrente do parentesco ou matrimônio, pois o preceito constitucional que permite a prisão por dívida, nas hipóteses de obrigação alimentar é de ser restritivamente interpretado, não tendo aplicação analógica às hipóteses de prestação alimentar derivada de ato ilícito." ${ }^{10}$

Acrescente-se que, embora não tenha sido mencionado pelo autor, também é cabível a aplicação do meio coercitivo para adimplemento de pensão decorrente de união estável.

b) A segunda ponderação a ser feita consiste na forma de execução destes alimentos ressarcitórios. Nas palavras de Freddie Didier Jr.:

\begin{abstract}
"é freqüente a afirmação de que a execução desses alimentos não pode ser feita pelos meios de execução previstos para outros tipos de alimentos - no caso, desconto em folha, a coerção pessoal e a expropriação. Para os alimentos indenizativos só se aplicaria o art. 475-Q CPC e a medida de constituição de renda adiante analisada. Essa é a orientação prevalecente na doutrina, mas combatida incisivamente por LUIZ GUILHEME MARINONI e SÉRGIO CRUZ ARENHART, que não vêem justificativa para o tratamento diferenciado. Ponderam inclusive que, muitas vezes, os alimentos indenizativos decorrem de ilícito incapacitante da vítima, que deles passa a depender para seu sustento. Permitir o uso de medidas mais agressivas e eficazes como o desconto em folha e a prisão civil seria exigência decorrente do direito fundamental a uma tutela efetiva $\left(\mathrm{CF} / 88\right.$, art. $\left.5^{\circ}, \mathrm{XXXV}\right)$."
\end{abstract}

Em síntese, conforme os ensinamentos de Ana Maria Gonçalves Louzada $^{11}$, os alimentos podem ser originários da lei (quando decorrem de vínculo de parentesco, casamento ou união estável), da vontade das partes (inter vivos ou causa mortis) ou do ato ilícito. No primeiro caso, os alimentos

\footnotetext{
${ }^{9}$ DIDIER JR., Fredie; CUNHA, Leonardo José Carneiro da; BRAGA, Paula Sarno; OLIVEIRA, Rafael. Ibid, p.690

${ }^{10}$ GONÇALVES, Carlos Roberto. Op. Cit., p.459

${ }^{11}$ LOUZADA, Ana Maria Gonçalves. Alimentos: Doutrina e Jurisprudência. Belo Horizonte: Del Rey, 2008. p. 7 e 8.
} 
pertencem ao direito de família; no segundo, ao direito das obrigações e ao direito das sucessões; o terceiro, ao direito obrigacional.

\subsection{Quanto à finalidade (estabilidade)}

\subsubsection{Alimentos Definitivos (ou regulares)}

Alimentos de caráter permanente, estabelecidos pelo juiz na sentença ou em acordo das partes devidamente homologado. Ainda que haja a possibilidade de revisão, isso não desnatura sua finalidade de alimentos regulares. Art.1699 $\mathrm{CC} / 02$.

Nas palavras de Freddie Didier:

"são aqueles estipulados na decisão final do juiz, dada em cognição exauriente, predisposta à imutabilidade e sujeita à execução definitiva. ${ }^{12}$,

\subsubsection{Alimentos Provisórios}

Alimentos fixados liminarmente no despacho inicial proferido na ação de alimentos, de rito especial estabelecido pela Lei n.5478/68. Tais alimentos exigem prova preconstituída do parentesco, casamento ou companheirismo. No mais, a fixação dos alimentos provisórios não está sujeita à discricionariedade do juiz. Presentes os requisitos para seu deferimento - requerimento e prova do vínculo - a fixação dos mesmos pelo juiz é obrigatória. Art. $4^{\circ}$ Lei de alimentos.

Da mesma forma, Freddie Didier Jr.:

“os alimentos provisórios são concedidos na própria ação em que se pedem os alimentos definitivos (de forma incidental). São os alimentos definitivos antecipados já na fase de postulação, até mesmo liminarmente, com base no art.4 da Lei n ${ }^{\circ} 5.478 / 68 . "$ 13

Conforme conceitua Ana Maria Gonçalves Louzada:

"Denominam-se alimentos provisórios aqueles deferidos initio litis, em ação de alimentos postulado pelo rito especial (art. $4^{\circ}$ da Lei n.5478/68) ou a posteriori (quando o credor expressamente declarar na inicial que deles não necessita), mas antes da sentença." 14

\subsubsection{Alimentos Provisionais ou ad litem}

Nos dizeres de Ana Maria Gonçalves Louzada:

\footnotetext{
${ }^{12}$ DIDIER JR., Fredie; CUNHA, Leonardo José Carneiro da; BRAGA, Paula Sarno; OLIVEIRA, Rafael. Op. Cit. p. 690

${ }^{13}$ Ibid, p.691

${ }^{14}$ LOUZADA, Ana Maria Gonçalves. Op. cit. p.4
} 
“os alimentos provisionais são aqueles previstos no art.852, incisos I, II e III, do CPC, e visam sustentar a parte durante o tramite processual (art.852, I, parágrafo único). Assim, tanto podem ser deferidos em ação autônoma como incidenter tantum, uma vez que esses alimentos podem ser postulados tanto em ação cautelar de alimentos quanto incidentalmente quando da propositura da ação de separação, divórcio, ou reconhecimento e dissolução de união estável." 15

Segundo Freddie Didier Jr.:

"são aqueles fixados antes ou durante a ação em que se pleiteiam alimentos definitivos (ação de alimentos, de separação, de divórcio, de nulidade/anulação de matrimônio, de dissolução de união estável, cf. art. $7^{\circ}$ da Lei n 9278/1996), por liminar ou sentença proferida em procedimento formalmente cautelar, regrado nos art.852 e ss.. Com eles, pretende-se garantir a subsistência do credor de alimentos na pendência da ação em que são demandados: trata-se de nítida hipótese de tutela antecipada.

Caracterizam-se, ainda, pela possibilidade de abranger uma verba suplementar, para custear despesas do processo pendente (CPC, art.852, parágrafo único) e por exigir o preenchimento de dois pressupostos legais e específicos, que são o receio do dano e a verossimilhança do direito a alimentos. De acordo com o artigo 1706 do Código Civil, os alimentos provisionais serão fixados pelo juiz, nos termos da lei processual, sede em que deve ser investigada sua real natureza." 16

Carlos Roberto Gonçalves acrescenta que em relação às despesas do processo pendente, poderia abranger inclusive as despesas com honorários advocatícios. Ainda, afirma que os alimentos provisionais têm eficácia até o término da ação principal podendo ser, a qualquer tempo, alterados ou revogados (CPC, art.807). ${ }^{17}$

Por fim, os alimentos provisionais sujeitam-se a discricionariedade do juiz e podem ser concedidos com base em meros indícios de parentesco sem a necessidade de prova preconstituída.

Em suma, as principais diferenças entre os alimentos provisórios e os alimentos provisionais são:

a) Alimentos provisórios não incluem verba de custeio de demanda (CPC, art.852, parágrafo único). Os alimentos provisionais admitem a abrangência dessa verba suplementar.

b) Alimentos provisórios pressupõem prova preconstituída da relação de parentesco ou da obrigação alimentar (art. $2^{\circ}$ Lei $\left.^{\circ} 5478 / 68\right)$. Ao revés, os

\footnotetext{
${ }^{15}$ Ibid. p. 4

${ }^{16}$ DIDIER JR., Fredie; CUNHA, Leonardo José Carneiro da; BRAGA, Paula Sarno; OLIVEIRA, Rafael. op. cit. p.691

${ }^{17}$ GONÇALVES, Carlos Roberto. Op.Cit. p. 459
} 
alimentos provisionais podem ser concedidos com base em meros indícios de parentesco.

c) Nos alimentos provisórios o juiz não precisa avaliar se tem periculum in mora e nem fumus boni juris (CPC, art.273). Já os alimentos provisionais sujeitam-se a discricionariedade do juiz ao avaliar os elementos autorizadores da medida cautelar.

Dito isto, algumas ressalvas devem ser feitas:

1. Não possuem natureza cautelar e sim satisfativa. Consequentemente, uma vez deferidos tais alimentos, a obrigação será prestada e os alimentos não poderão ser repetidos. Nesse sentido, Freddie Didier Jr.:

“tanto os alimentos provisionais como os provisórios são dados em antecipação dos efeitos da tutela. Nenhum deles tem natureza cautelar, afinal, são satisfativos: satisfazem imediatamente a prestação, não se limitando a assegurar sua futura satisfação. Daí aplicar-se a ambos o disposto no art.273 do CPC. Rigorosamente, a distinção não é essencial: ambos são alimentos provisórios, pois não definitivos e provisionais, pois servem a satisfação do alimentando ("provisão"). Distinguem-se pelo nome e pelos pressupostos de concessão. A previsão de alimentos provisionais no Código de Processo Civil serve como regra geral da antecipação dos efeitos da tutela alimentar, e a previsão dos alimentos provisórios, como regra específica." 18

2. Quanto à classificação dos alimentos em definitivos, provisionais ou provisórios, Freddie Didier Jr. pondera:

"considerando a estabilidade da decisão que os concede, não servem como critério para determinar os meios de execução cabíveis para efetivá-los, como parecem estabelecer os arts. 733 e 735 do CPC, que só prevêem prisão civil e expropriação para os alimentos provisionais. Caso contrário, prevaleceria a absurda idéia de só se admitir o uso da técnica mais agressiva e efetiva, que é a prisão civil, para realização de alimentos fixados por decisão instável e provisória." 19

Diante disso, Freddie Didier Jr. transcreve a lição de MARINONI e ARENHART da qual se conclui que a correta interpretação sistemática dos dispositivos que tratam do tema - CPC, Lei de Alimentos (L.5478/68) e a Lei 6014/73 (que alterou a lei de alimentos) - é no sentido de aplicar todo o regime previsto no CPC para os alimentos provisionais aos alimentos definitivos (art.16 e 18 da lei de alimentos) e vice-versa. Em relação aos alimentos provisórios, por

\footnotetext{
${ }^{18}$ DIDIER JR., Fredie; CUNHA, Leonardo José Carneiro da; BRAGA, Paula Sarno; OLIVEIRA, Rafael. p.691

${ }^{19}$ Ibid. p.691
} 
refletirem antecipação dos definitivos, poderão contar com os mesmos meios de execução utilizados pelos alimentos provisionais e definitivos. ${ }^{20}$

\subsection{Quanto ao momento em que são reclamados}

Carlos Roberto Gonçalves aponta três classificações (alimentos pretéritos, atuais e futuros). Em seguida, admite que essa classificação não se amolda perfeitamente ao direito brasileiro.

Afinal, alimento pretérito propriamente dito (quando o pedido retroage a período anterior ao ajuizamento da ação) não é passível de cobrança no direito brasileiro.

Ainda esclarece que, na prática, os alimentos pretéritos têm sido confundidos com prestações pretéritas (fixadas na sentença ou acordo, estando há muito tempo vencidas e não cobradas, a ponto de não se poder tê-las mais por indispensáveis à sobrevivência e, por isso, passam a constituir um crédito como outro qualquer apto a ser cobrado na forma de execução por quantia certa prevista no art.732 do CPC).

Quanto aos alimentos futuros (que classifica como sendo os devidos somente a partir da sentença) diz que independem do trânsito em julgado da decisão que os concedem, sendo devidos a partir da citação ou do acordo. ${ }^{21}$

Com base nessas considerações, é possível compreender porque Freddie Didier Jr. aponta somente uma dupla classificação dos alimentos quanto ao momento em que são reclamados. Segundo renomado doutrinador, os alimentos podem ser pretéritos ou futuros.

A importância dessa classificação está diretamente relacionada à forma como será processada a execução dos mesmos conforme se verá a seguir.

\subsubsection{Alimentos Futuros}

Segundo Freddie Didier Jr.:

"são aqueles devidos desde o momento em que há sentença transitada em julgado, decisão antecipatória eficaz ou acordo firmado entre as partes." 22

\footnotetext{
${ }^{20}$ Ibid. p.692

${ }^{21}$ GONÇALVES, Carlos Roberto. Op. cit. p.461 e 462
} 
A execução desses alimentos segue o rito do art. 733 do CPC e diz respeito apenas às três últimas prestações devidas antes da execução e às que se vencerem após a propositura da execução. Nesse sentido, está a súmula 309 do STJ. Quanto à execução de alimentos futuros se admite a prisão civil como medida executiva.

\subsubsection{Alimentos Pretéritos}

São os alimentos anteriores a sentença transitada em julgado, decisão antecipatória eficaz ou acordo firmado entre as partes e acumulados desde a sua constituição e cobrança em sede de execução. ${ }^{23}$

Para estes alimentos, o rito a ser adotado é o do art.732 do CPC. Logo, não se aplicam aos alimentos pretéritos, cujas prestações antecedem as três últimas anteriores ao ajuizamento da execução, as peculiaridades do art.733 do CPC.

No mesmo sentido, Carlos Roberto Gonçalves:

"Têm os tribunais proclamado que a prisão civil somente poderá ser imposta para compelir o alimentante a suprir necessidades atuais do alimentário, representada pelas três ultimas prestações, devendo as pretéritas ser cobradas em procedimento próprio." ${ }^{24}$

Maria Berenice Dias faz uma reflexão interessante acerca desse tema em seu livro conversando sobre alimentos. Segundo a jurista, não pagar alimentos é um grande negócio. Observe a transcrição:

"Vamos às leis. É tal a barafunda entre a lei de alimentos e o que diz o Código de Processo Civil, que nem se sabe qual é o prazo da prisão. A lei de alimentos (L.5478/68, art.19) autoriza a prisão do devedor por até sessenta dias. Já o Código de Processo Civil, no art. $733 \S 1^{\circ}$, prevê a prisão pelo prazo de um a três meses.

Não bastasse isso, há outro detalhe que merece ser chamado no mínimo de insólito. Quanto mais o devedor deve, mais chance tem de não ir para a cadeia.

Não está na lei. Mas está consolidado na jurisprudência que quem deve mais de três meses de pensão alimentícia simplesmente não pode ser executado pelo rito da coação pessoal, ou seja, está livre da prisão.

A mora produz uma alquimia: transforma os alimentos. A dívida faz com que os alimentos mudem de natureza. Assim, os alimentos deixam de ser alimentos.

Até parece que a solução é dever, e dever bastante.” 25

\footnotetext{
${ }^{22}$ DIDIER JR., Fredie; CUNHA, Leonardo José Carneiro da; BRAGA, Paula Sarno; OLIVEIRA, Rafael. op. cit. p.692

${ }^{23}$ Ibid. p. 693

${ }^{24}$ GONÇALVES, Carlos Roberto. Op. cit. p. 462

${ }^{25}$ DIAS, Maria Berenice. Conversando sobre Alimentos. Porto Alegre: Livraria do Advogado Ed., 2006. p.13
} 


\title{
2.5. Alimentos Transitórios
}

Ensina Ana Maria Gonçalves Louzada que alimentos transitórios seriam aqueles cujo prazo final já estaria previamente estabelecido. A título de exemplo: os alimentos pagos a ex-cônjuges ou ex-companheiros, que possuam qualificação profissional e sejam jovens; ainda, a obrigação alimentar dos pais em relação aos filhos cujo termo final seria aos 24 anos ou até o término do curso superior, o que se vencer primeiro.

Para a jurista, qualquer que seja o caso, é necessário observar no caso concreto os pressupostos da obrigação alimentar: necessidade e possibilidade. Isso porque nem sempre é fácil a inserção no mercado de trabalho. Assim, apesar do marco final, o alimentando poderia requerer a continuidade da pensão. Da mesma forma, o filho que implemente a condição objetiva, poderá, comprovando sua necessidade e a possibilidade de seus ascendentes, requerer a manutenção da pensão. Nesses termos, Ana Maria Gonçalves Louzada:

\begin{abstract}
"Destarte, estabelecer-se um marco final para o pagamento da pensão alimentícia sem sopesar os vértices da obrigação alimentar, não nos parece aceitável. Assim, caso o genitor deseje a exoneração da pensão alimentícia, deverá adentrar com o feito exoneratório, demonstrando sua impossibilidade financeira na mantença da obrigação e/ou a falta de necessidade por parte do filho. O simples implemento de um dado objetivo (24 anos ou conclusão do curso superior), por si só, não subsidia a exoneração alimentar." 26
\end{abstract}

\section{Do direito aos alimentos}

\subsection{Obrigação de Prestar alimentos versus dever familiar}

Conforme ensina Carlos Roberto Gonçalves são inconfundíveis os termos obrigação alimentar e dever familiar (como sustento, mútua assistência art.1566, III e IV e art.1724 CC).

O dever familiar deve ser cumprido incondicionalmente, não concorrendo para isso os pressupostos da obrigação alimentar, isto é, o dever existe independentemente da comprovação do estado de necessidade. Importante ponderar que, em tese não se avaliam os pressupostos da obrigação alimentar (binômio possibilidade-necessidade) no dever de sustento. Na prática será preciso quantificar o valor da pensão e, para isso, será realizada essa análise.

\footnotetext{
${ }^{26}$ LOUZADA, Ana Maria Gonçalves. Op.cit. p. 7
} 
Em sentido oposto, a obrigação alimentar, para existir, deve passar pela análise dos pressupostos de necessidade de quem pede e possibilidade de quem irá arcar com o valor da pensão.

Dito isto, dispõe o art. 1566, IV do código civil de 2002 que é dever de ambos os cônjuges o sustento, a guarda e a educação dos filhos. Nesse sentido, o código traz uma imposição legal dirigida a determinadas pessoas ligadas pelo vínculo familiar. Tal imposição é unilateral e deve ser cumprida incondicionalmente.

Rolf Madaleno explica que o dever de sustento está vinculado ao poder familiar, ao parentesco das pessoas menores e incapazes. ${ }^{27}$ Assim, ainda quando, por advento de uma separação, um dos pais se afasta da companhia dos filhos, subsiste o dever de sustento. Afinal, conforme preceitua o art. 1632 do Código Civil, subsiste o poder familiar. Nesse caso, o dever de sustento aparece na forma de obrigação alimentar. Não se trata da obrigação alimentar propriamente dita, e sim dever de sustento.

Em relação aos filhos maiores, o que haveria seria obrigação alimentar. Para tanto, os filhos maiores, para receberem alimentos de seus pais, deveriam comprovar sua necessidade e a possibilidade de seus genitores em arcar com a pensão. Ainda, o fundamento do pedido não seria o dever de sustento e sim o princípio da solidariedade familiar.

É importante notar que o dever de sustento recai somente sobre os pais, não se estende a outros ascendentes e não é recíproco. Ao revés, a obrigação alimentar pode recair sobre outros parentes, como por exemplo, os avôs (art.1696 CC); e é recíproca, isto é, o devedor de hoje pode vir a ser o credor dos alimentos no futuro. Assim, enquanto o dever de sustento é somente dos pais em direção aos filhos menores, a obrigação alimentar é uma via de mão dupla entre pais e filhos. Nesse sentido, Carlos Roberto Gonçalves:

"O dever de sustentar os filhos menores é expresso no art.1566, IV, do código civil e é enfatizado nos arts.1634, I, e 229, este da Constituição. Decorre do poder familiar e deve ser cumprido incondicionalmente, não concorrendo os pressupostos da obrigação alimentar, subsiste independentemente do estado de necessidade do filho, ou seja, mesmo que este

\footnotetext{
${ }^{27}$ MADALENO, Rolf. Obrigação, dever de assistência e alimentos transitórios. 2004. Disponível em: http://www2.cjf.jus.br/ojs2/index.php/cej/article/viewFile/636/816. Acesso em: 15 abr. 2011
} 
disponha de bens, recebidos por herança ou doação. Cessa quando o filho se emancipa ou atinge a maioridade, aos 18 anos de idade. Nessas hipóteses, deixa de existir o dever alimentar decorrente do poder familiar, mas pode surgir a obrigação alimentar, de natureza genérica, decorrente do parentesco (CC, art.1694).

Assim, os filhos maiores que, por incapacidade ou enfermidade, não estiverem em condições de prover à própria subsistência, poderão pleitear também alimentos, mas com este outro fundamento, sujeitando-se à comprovação dos requisitos da necessidade e da possibilidade. Tal obrigação pode durar até a morte." 28

Em relação aos cônjuges e companheiros aparece o dever de mútua assistência (art.1566, III CC/02). Assim, na constância da relação existe o dever incondicional de prestar assistência ao outro cônjuge ou companheiro. Finda a relação, o pleito alimentar passa a ser fundamentado no princípio da solidariedade e, consequentemente, para ser deferido será necessária a análise do binômio possibilidade-necessidade.

Em relação a este ponto, Carlos Roberto Gonçalves apresenta citação de Orlando Gomes, a saber:

"o dever de sustento que incumbe ao marido, toma, entretanto, feição de obrigação de alimento embora irregular, quando a sociedade conjugal se dissolve pela separação judicial, ocorrendo a mesma desfiguração em relação aos filhos do casal desavindo. No rigor dos princípios, não se configura, nesses casos, a obrigação propriamente dita, de prestar alimentos, mas, para certos efeitos, os deveres de sustento, assistência e socorro adquirem o mesmo caráter." 29

Ainda dissertando sobre o tema, Rolf Madaleno ensina:

“(...) os alimentos entre pais e filhos dimanam do poder familiar, sobre eles recaindo presunção absoluta de necessidade. Já com relação à pensão devida aos filhos adultos, maiores de dezoito anos, e aos demais parentes, ou entre cônjuges e companheiros, todos declinados do art.1694 do Código Civil de 2002, não mais milita essa presunção de necessidade, que precisa ser demonstrada.

Portanto, a necessidade dos alimentos é absoluta em relação aos filhos sob o poder familiar, e relativa quanto as filhos maiores e capazes. Também é relativa no que diz respeito aos demais parentes e aos cônjuges ou companheiros." 30

Importante destacar o equívoco do autor ao falar em presunção relativa de necessidade. Não há qualquer presunção no campo da obrigação alimentar. A pessoa necessitada tem que ingressar em juízo provando sua necessidade. Se houvesse presunção relativa de necessidade, o ônus da prova seria do alimentante. $\mathrm{O}$ alimentante teria que provar que o alimentando não necessita dos

\footnotetext{
${ }^{28}$ GONÇALVES, Carlos Roberto. op. cit. p.488 e 489

${ }^{29}$ GONÇALVES, Carlos Roberto. Apud. p. 463

${ }^{30}$ MADALENO, Rolf. Obrigação, dever de assistência e alimentos transitórios. 2004. Disponível em: http://www2.cjf.jus.br/ojs2/index.php/cej/article/viewFile/636/816. Acesso em: 15 abr. 2011.
} 
alimentos. Assim, falar em presunção relativa de necessidade implicar em uma inversão de ônus da prova que não existe no direito civil. Quem deve provar que necessita de alimentos é o necessitado e não o alimentante ter de provar que o alimentado deles não necessita.

Por todo o exposto, é possível concluir que o dever de sustento é incondicional, não se avaliam os pressupostos da obrigação alimentar (possibilidade-necessidade) - em tese, conforme dito anteriormente - e decorre do poder familiar. $\mathrm{O}$ dever de sustento recai somente sobre os pais, não se estende a outros descendentes e não é recíproco. Ao revés, a obrigação alimentar está sujeita a análise de pressupostos de possibilidade e necessidade, é recíproca, decorre do casamento, união estável ou da relação de parentesco. Relação de parentesco pode ser entendida como sendo extensiva aos parentes em linha reta e colaterais até o segundo grau (ou seja, se dá entre todos os ascendentes e descendentes conforme o art.1694 do Código Civil e não somente dos pais para os filhos como ocorre com o dever de sustento).

\subsection{Características da obrigação}

\subsubsection{Transmissibilidade}

O novo código civil admite a transmissibilidade da obrigação de prestar alimentos (arts. 1694 e 1700 CC/02) seja esta em razão de parentesco, casamento ou união estável. Trata-se de inovação em matéria alimentar uma vez que o código civil de 1916 tratava a obrigação como sendo intransmissível.

Todavia, a questão da transmissibilidade da obrigação suscita alguns questionamentos entre os doutrinadores, a saber:

a) Transmissão é da própria obrigação ou somente se daria quanto às prestações vencidas e não pagas?

A melhor interpretação a ser feita sugere que a obrigação alimentar não se transmite em sua potencialidade e sim em sua atualidade. Em outros termos, ocorre a transmissão de prestar alimentos desde que esses alimentos já estejam fixados a data do óbito ou ainda, quando ao menos já existisse demanda em relação ao falecido visando o pagamento de obrigação alimentar. Pretensões 
alimentares posteriores ao óbito não devem ter escopo no art.1700 do código civil de 2002.

No mesmo sentido, explica Ana Maria Gonçalves Louzada:

"O que se transmite é a obrigação alimentar e não o dever de prestar alimentos. Assim, para que haja essa transmissibilidade, reiteramos, necessário que anteriormente à morte do de cujos, já exista obrigação alimentar fixada judicialmente.

Como o que se transmite é a obrigação de prestar alimentos (e não somente a dívida alimentar), nos exatos termos do art. 1700 do Código Civil, não só os alimentos vencidos, mas também os vincendos, devem ser suportados pelas forças da herança." 31

Por fim, Carlos Roberto Gonçalves acrescenta o posicionamento de Zeno Veloso:

“O art.1700, a meu ver, só pode ter aplicação se o alimentado não é por sua vez, herdeiro do devedor da pensão. E, ainda, esse artigo só pode ser invocado se o dever de prestar alimentos já foi determinado por acordo ou por sentença judicial." 32

b) A transmissão é feita de acordo com as forças da herança (art.1792 $\mathrm{CC} / 02$ ) ou na proporção das necessidades do reclamante e dos recursos da pessoa obrigada (art.1694\$ $\left.1^{\circ} \mathrm{CC} / 02\right)$ ?

Primeiramente, a transmissão da obrigação se dá nos limites da força da herança (art.1792 CC/02) ainda que o artigo 1700 do código civil de 2002 seja omisso a respeito. Com base nisto, é preciso avaliar o grau de necessidade do alimentando. A proporcionalidade se dará no caso com base nas forças da herança e não com base nos recursos da pessoa obrigada. Explique-se:

Quando a necessidade for menor do que a herança deixada, a pensão será fixada a menor. Ao revés, sendo maior a necessidade do que o saldo de herança, a pensão não poderá ultrapassar o limite desta e, portanto, será fixada tendo como teto máximo os limites da herança.

Nesse sentido, Carlos Roberto Gonçalves:

“A remissão que o aludido art.1700 do código civil faz à transmissão aos herdeiros da
obrigação de prestar alimentos na forma do art.1694, se por um lado obriga o seu
dimensionamento na proporção das necessidades do reclamante e dos recursos da
pessoa obrigada ( $\$ 1^{\circ}$ do art. 1694$)$, por outro não afasta o limite das forças da herança, a
prova das apontadas necessidades. Se estas forem menores, a pensão poderá ser fixada
em montante abaixo do referido limite, mas em nenhuma hipótese poderá excedê-lo." ${ }^{33}$

${ }^{31}$ LOUZADA, Ana Maria Gonçalves. Op. cit. p. 20 e 21

${ }^{32}$ GONÇALVES, Carlos Roberto. op. cit. p. 465

${ }^{33}$ GONÇALVES, Carlos Roberto. op. cit. p.466 
Da mesma forma, explica Ana Maria Gonçalves Louzada:

"Ademais, a quem é transmitida a obrigação é ao espólio, vale dizer que, em não havendo bens, não haverá a transmissão da obrigação alimentar. (...)

Dessa forma, o encargo alimentar subsistirá até a efetivação da partilha. A partir da divisão dos bens, não cabe mais falar em sucessores, os quais não respondem com seu patrimônio particular pelo pagamento de obrigação alimentar do devedor falecido.

Significa dizer que, não havendo herança, ou sendo insuficiente o acervo hereditário para suportar o pagamento da obrigação pensional deixada pelo alimentante, não há como responsabilizar pessoalmente os herdeiros pela manutenção do encargo em face do credor." 34

c) $\mathrm{O}$ art.1700 fala apenas em herdeiros. Isso poderia levar a conclusão de que a obrigação não se transmitiria somente aos irmãos, colaterais em segundo grau e obrigados por lei (art.1697 CC/02), mas também atingiria tios, sobrinhos e primos, colaterais em quarto grau (art.1839 CC/02).

\subsubsection{Divisibilidade}

A obrigação alimentar é, em regra, divisível e não-solidária. Isso quer dizer que havendo mais de um devedor, cada um responderá por sua quota parte. Caso o credor implemente ação somente contra alguns dos devedores, não poderá cobrar dos mesmos a quota dos demais. Portanto, receberá a menor sua pensão.

As quotas não necessariamente serão idênticas. A quota de cada um deverá atender ao critério necessidade-possibilidade, ou seja, todos concorrerão na proporção de seus recursos (art.1698 CC/02).

Por fim, cabe esclarecer que a regra de que os alimentos são divisíveis e não-solidários comporta exceção presente no art.12 da lei 10.071/2003 que instituiu a solidariedade da obrigação alimentar quando o alimentando for maior de 60 anos.

\subsubsection{Condicionalidade}

Diz-se que a obrigação alimentar é condicional porque sua concessão tem como pressupostos a necessidade do reclamante e a possibilidade do reclamado em arcar com a pensão (art.1694\$ $\left.1^{\circ} \mathrm{CC} / 02\right)$.

\footnotetext{
${ }^{34}$ LOUZADA, Ana Maria Gonçalves. Op. cit. p. 21 e 22.
} 
Caso o reclamante adquira meios de prover a própria subsistência ou o reclamado não tenha meios de auxiliá-lo sem prejuízo do próprio sustento, o encargo se extingue.

\subsubsection{Reciprocidade}

Com fulcro no artigo 1696 do código civil, é possível afirmar que o direito de exigir alimentos implica no dever de prestá-los porque a obrigação é recíproca. Quanto isso, Carlos Roberto Gonçalves pondera:

"Os direitos coexistem apenas no estado potencial. A reciprocidade não indica que duas pessoas devam entre si alimentos simultaneamente, mas apenas que o devedor de hoje pode tornar-se o credor de alimentos no futuro." 35

\section{Conforme lembra Caio Mario:}

"A reciprocidade do dever alimentar entre pais e filhos é proclamada no art.229 da Constituição." 36

\subsubsection{Mutabilidade}

A mutabilidade está estreitamente relacionada com a possibilidade de alteração dos pressupostos da necessidade e possibilidade. Assim, é permitida a alteração da pensão mediante ação revisional ou de exoneração (art.1699 CC/02). Por isso, diz-se que decisões acerca de alimentos estão sujeitas a cláusula rebus sic stantibus, ou seja, alterada a situação fática que deu origem aquela decisão, também será modificado seu resultado. Nesse sentido, Carlos Roberto Gonçalves:

"O quantum fixado não é imutável, pois se houver modificação na situação econômica das partes, poderá qualquer delas ajuizar ação revisional de alimentos, com fundamento no art.1699 do código civil, para pleitear a exoneração, redução ou majoração do encargo. As sentenças proferidas em ações de alimentos trazem incita a cláusula rebus sic stantibus, pois o montante da prestação tem como pressuposto a permanência das condições de necessidade e possibilidade que o determinaram. O caráter continuativo da prestação impede que ocorra coisa julgada material. $\mathrm{O}$ efeito da preclusão máxima se opera apenas formalmente, possibilitando eventual modificação posterior do montante estabelecido." 37

\footnotetext{
${ }^{35}$ GONÇALVES, Carlos Roberto. op. cit. p. 473

${ }^{36}$ PEREIRA, Caio Mario da Silva. op. cit. p. 499

${ }^{37}$ GONÇALVES, Carlos Roberto. op. cit. p. 487
} 


\subsection{Características do direito aos alimentos}

\subsubsection{Personalíssimo}

Por se tratar de um direito inato da personalidade ligado a subsistência do indivíduo é pessoal e intransferível, não se alterando sua titularidade.

Nas palavras de Ana Maria Gonçalves Louzada:

"Significa dizer que os alimentos só podem ser requeridos pela pessoa que deles precise. Assim, caso o filho esteja necessitando de alimentos de seu genitor, é em seu nome que deve requerer o pensionamento alimentar, ainda que representado ou assistido por sua mãe." 38

\subsubsection{Incessível}

Por se tratar de direito personalíssimo, inafastável da pessoa, não pode ser objeto de cessão (art.1707 CC/02). Entretanto, observe a transcrição feita por Carlos Roberto Gonçalves:

"No entanto, somente não pode ser cedido o direito a alimentos futuros. O crédito constituído por pensões alimentares vencidas é considerado um crédito comum, já integrado ao patrimônio do alimentante, que logrou sobreviver sem tê-lo recebido. Pode, assim, ser cedido." 39

\subsubsection{Impenhorável}

O art.1707 do Código Civil proíbe a penhora do crédito alimentar tendo em vista ser este destinado a manutenção da vida.

Dessa forma, afirma Ana Maria Gonçalves Louzada ${ }^{40}$ que, o credor da pensão alimentícia não terá seu crédito penhorado. Ao revés, o devedor de alimentos pode ter, até mesmo, seu bem de família penhorado uma vez que não está sujeito a proteção da Lei 8009/90.

Cabe lembrar que, em relação os bens impenhoráveis, a regra da impenhorabilidade contida no art.649, inc. IV do CPC pode ser afastada para suprir o pagamento da pensão alimentícia (art. $649 \S 2^{\circ} \mathrm{CPC}$ ). Quanto aos demais incisos, ainda que se trate de execução de alimentos, prevalece a impenhorabilidade.

\footnotetext{
${ }^{38}$ LOUZADA, Ana Maria Gonçalves. op. cit. p.11

${ }^{39}$ GONÇALVES, Carlos Roberto. op. cit. p.474

${ }^{40}$ LOUZADA, Ana Maria Gonçalves. op. cit. p 15
} 
Carlos Roberto Gonçalves trazendo a lição de Orlando Gomes ${ }^{41}$ acrescenta ser inadmissível a cisão que alguns autores propõem quanto ao crédito alimentar de acordo com sua natureza (naturais ou civis) para aplicar a impenhorabilidade. Nesse sentido, a proteção legal não se estenderia a totalidade do crédito, mas só a parte necessária para a subsistência, ou seja, a impenhorabilidade somente garantia a parte do crédito alimentar que representasse os alimentos indispensáveis a subsistência.

Por fim, ressalta Carlos Roberto Gonçalves que a impenhorabilidade pode recair na soma de alimentos provenientes do recebimento das prestações atrasadas.

\subsubsection{Incompensável}

Compensação é meio de extinção da obrigação entre pessoas que são simultaneamente credores e devedores umas das outras.

Não pode ocorrer compensação no seara dos alimentos tendo em vista a finalidade dos mesmos: subsistência do ser humano. Todavia, para evitar o enriquecimento sem causa a jurisprudência pondera admitindo compensação, nas prestações vincendas, dos valores pagos a mais. Segundo a jurisprudência, nesse caso, teria ocorrido adiantamento do pagamento das futuras prestações apto a ser compensado.

\subsubsection{Imprescritível}

Importante diferenciar o direito de postular em juízo e o direito de cobrar pensões já fixadas e não pagas. No primeiro caso, não opera a prescrição; já no segundo, a prescrição se opera após dois anos contados da data em que se vencerem (art.206 $\left.\$ 2^{\circ} \mathrm{CC} / 02\right)$. As prescrições, nessa hipótese, são mensais. Ainda, não se deve falar em prescrição, no segundo caso, quando a execução de alimentos for proposta por alimentando absolutamente incapaz porque contra ele não corre prescrição (arts.197, II e 198, I CC/02). Por fim, não opera prescrição no exercício do poder familiar.

\footnotetext{
${ }^{41}$ GONÇALVES, Carlos Roberto. op. cit. p. 475
} 


\subsubsection{Intransacionável}

É preciso diferenciar o direito de pedir alimentos (indisponível e personalíssimo) do quantum das prestações (tanto as vencidas quanto as vincendas). Quanto ao direito, não cabe transação, não pode ser objeto de juízo arbitral ou de compromisso. Em relação ao quantum das prestações, a transação é admitida.

\subsubsection{Irrepetível ou irrestituível}

Os alimentos, uma vez pagos, são irrestituíveis quaisquer que seja sua natureza (definitivos, provisórios ou provisionais). Assim, mesmo que ação alimentícia venha a ser julgada improcedente, não cabe a restituição dos alimentos provisórios ou provisionais.

O princípio da irrepetibilidade dos alimentos encontra dois limites:

a) quando houver dolo na sua obtenção

b) quando houver erro no pagamento dos alimentos que gere enriquecimento sem causa que não se justifica. Carlos Roberto Gonçalves fornece, a título de exemplo, a cessação automática da obrigação devido ao segundo casamento da credora, não tendo cessado o desconto em folha de pagamento por demora na comunicação ao empregador, sem culpa do devedor, bem como a compensação nas prestações vincendas. ${ }^{42}$

Caio Mario traz o alerta de YUSSEF CAHALI no sentido de que, em razão da irrepetibilidade dos alimentos, não cabe caução para o seu levantamento. ${ }^{43}$

\subsubsection{Irrenunciável}

A irrenunciabilidade atinge o direito e não seu exercício. Assim, o credor de alimentos pode não exercer o direito aos alimentos através da não-postulação em juízo, mas isso não implica em renúncia. Não existe renúncia em relação aos alimentos futuros. Há qualquer tempo o credor poderá pleitear alimentos caso

\footnotetext{
${ }^{42}$ GONÇALVES, Carlos Roberto. op. cit. p.477

${ }^{43}$ PEREIRA, Caio Mario da Silva. op. cit. p. 502
} 
venha a necessitar. Qualquer cláusula que estabeleça renúncia aos alimentos será considerada não escrita.

Quanto a isso, afirma Carlos Roberto Gonçalves:

"Os alimentos devidos e não prestados podem, no entanto, ser renunciados, pois é permitido o não-exercício do direito a alimentos. A renúncia posterior é, portanto, válida." 44

No mesmo sentido, Caio Mario:

“As prestações alimentares já vencidas, como valores patrimoniais, podem ser renunciadas e podem ser objeto de transação." 45

\subsection{Pressupostos da Obrigação Alimentar (Arts. $1964 \S^{1}$ e 1965 CC/02)}

\subsubsection{Existência de um vínculo de parentesco}

Conforme o artigo 1694 do Código Civil, os alimentos são devidos entre parentes (ascendentes, descendentes ou irmãos), cônjuges ou companheiros.

\subsubsection{Necessidade do reclamante}

Entende-se por necessidade "quando quem os pretende não tem bens suficientes, nem pode prover pelo seu trabalho, à própria mantença.” (art.1695 $\mathrm{CC})$

Nesse ponto, Carlos Roberto Gonçalves faz duas importantes ponderações:

"Não importa a causa pela qual o reclamante foi reduzido a condição de necessitado, tendo direito a pensão ainda que culpado por essa situação. Nesse caso, entretanto, os alimentos serão apenas os indispensáveis à sua subsistência. (art.1694§ $2^{\circ} \mathrm{CC} / 02$ )" 46

"Aplica-se aos alimentos devidos em razão do casamento ou união estável o disposto no parágrafo único do art.1708 do código civil, segundo o qual cessa também o direito do credor a alimentos, se tiver procedimento indigno em relação ao devedor. Nesse caso, não fará jus nem mesmo aos alimentos indispensáveis." ${ }^{47}$

\footnotetext{
${ }^{44}$ GONÇALVES, Carlos Roberto. op. cit. p. 478

${ }^{45}$ PEREIRA, Caio Mario da Silva. op. cit. p. 500

${ }^{46}$ GONÇALVES, Carlos Roberto. op. cit. p. 484

${ }^{47}$ Ibid.
} 


\subsubsection{Possibilidade da Pessoa Obrigada}

Entende-se por possibilidade quando "aquele, de quem se reclamam (os alimentos), pode fornecê-los sem desfalque do necessário ao seu sustento." (Art.1695, segunda parte CC/02)

Nesse sentido, Carlos Roberto Gonçalves com base nos ensinamentos de Washington Monteiro de Barros:

"Se o alimentante possui tão somente o indispensável à própria mantença, não é justo que seja ele compelido a desviar parte de sua renda, a fim de socorrer o parente necessitado. A lei não quer o perecimento do alimentado, mas também não deseja o sacrifício do alimentante. Não há direito alimentar contra quem possui estritamente o necessário à própria subsistência." ${ }^{48}$

Complementando o disposto acima, conclui Caio Mario:

"Se o alimentante não os puder fornecer em razão de seu próprio sustento, prestá-los-á dentro daqueles limites, cumprindo ao alimentando reclamar de outro parente a complementação." 49

\subsubsection{Proporcionalidade}

O artigo $1694 \S 1^{\circ}$ do Código Civil estabelece ao magistrado o dever de ponderar a necessidade do reclamante e possibilidade do reclamado, buscando o equilíbrio entre eles, isto é, o juiz não deve pautar sua decisão na fixação de uma pensão que leve em consideração somente um destes vetores. Nesse sentido, Caio Mario afirma:

"Não tem cabida exigi-los além do que o credor precisa, pelo fato de ser o devedor dotado de altas posses; nem pode ser este compelido a prestá-los com sacrifício próprio ou da sua família, pelo fato de o reclamante os estimar muito alto, ou revelar necessidades maiores" 50

Carlos Roberto Gonçalves pondera afirmando que os recursos da pessoa obrigada a que se refere o art.1694 $\S 1^{\circ}$ do Código Civil são seus rendimentos. Assim, não se deve constranger o devedor a alienar imóvel para atender as necessidades do alimentante. ${ }^{51}$

\footnotetext{
${ }^{48}$ GONÇALVES, Carlos Roberto. op. cit. p. 485

${ }^{49}$ PEREIRA, Caio Mario da Silva. op. cit. p. 498

${ }^{50}$ PEREIRA, Caio Mario da Silva. op. cit. p. 498

${ }^{51}$ GONÇALVES, Carlos Roberto. op. cit. p.486
} 


\subsection{Pressupostos subjetivos}

\subsubsection{Quem deve alimentos}

Os artigos 1696 e 1697 do Código Civil trazem o rol taxativo acerca de quem pode figurar no pólo passivo. Segundo Carlos Roberto Gonçalves, não estaria incluso no rol os parentes por afinidade (sogros, cunhados, padrastos, enteados). Todavia, importante salientar que, embora não tenham de prestar obrigação alimentar, se o fizerem, não terão direito a repetição.

Além dos artigos 1696 e 1697 do Código Civil que trazem o rol das pessoas obrigadas em razão do parentesco (ascendentes, descendentes e irmãos), temos o artigo 1694 que também inclui os cônjuges e companheiros na lista. Assim, sendo o alimentando casado, deve primeiro propor ação contra seu cônjuge antes de propô-la contra algum de seus parentes.

Ana Maria Gonçalves Louzada traz ainda para o pólo alimentar a questão da filiação socioafetiva. Segundo a autora, quando comprovado que o genitor sempre tratou o filho como se fosse seu (ainda que não seja seu pai consangüíneo) constituindo para este e para a sociedade a posse do estado de filho ou; ainda, quando o genitor registra o filho como sendo seu (adoção a brasileira), eventual negatória de paternidade não logrará êxito. ${ }^{52}$ Desse modo, reconhecido como pai, estará sujeito a obrigação alimentar. Nesse sentido, conclui a autora:

"Ocorre que o art.1609 do CC prevê hipótese de o reconhecimento dos filhos ser irrevogável. Em outras palavras, caso o genitor tenha registrado o menor como sendo seu filho, não poderá requerer sua desconstituição e, por conseguinte, a extinção da obrigação alimentar, nos termos do art.1604 e 1610 do CC.

De igual modo, estabelecendo-se uma sólida ligação de afeto entre pai e filho, ainda que esse seja decorrente apenas de posse de estado de filho, a obrigação alimentar deve persistir contra aquele que é considerado pelo menor como sendo seu pai, respeitando-se os princípios constitucionais da dignidade da pessoa humana, solidariedade humana e maior interesse da criança e do adolescente." 53

Dito isto, podem figurar no pólo passivo em razão do parentesco, na seguinte ordem preferencial:

a) Pais e filhos, reciprocamente

\footnotetext{
${ }^{52}$ LOUZADA, Ana Maria Gonçalves. Op. cit. p. 37

${ }^{53}$ LOUZADA, Ana Maria Gonçalves. Op. cit. p. 38 e 39
} 
Quanto aos pais e filhos, ficam as considerações trazidas acerca do dever de sustento e a obrigação alimentar expostas ao longo deste trabalho. Nesse sentido, quando cessa o dever de sustento, inicia-se a obrigação alimentar propriamente dita e, esta sim, será recíproca.

Além disso, os pais são os primeiros na ordem preferencial de parentesco a serem chamados para prestar alimentos. Somente na falta destes, ou na impossibilidade de prestá-los de forma satisfatória é que se pode recorrer aos avôs para complementar a pensão.

Em relação a esse tópico, leciona Ana Maria Gonçalves Louzada:

"Enquanto os filhos são menores de idade, encontram-se sob o poder familiar (art.1634 do CC), tendo os pais o dever de sustentá-los. Atingida a maioridade, extingue-se o poder familiar, o que não implica dizer, necessariamente, a extinção da obrigação de prestar alimentos, pois essa persiste como dever de solidariedade advinda da relação de parentesco existente entre pais/filhos. Vale dizer, a maioridade pode conduzir a extinção da obrigação alimentar, desde que fique também demonstrado que o alimentando não se encontra mais necessitado e/ou não possua o genitor qualquer condição financeira de mantê-lo economicamente, nos termos do art. 1699 do CC." 54

b) $\mathrm{Na}$ falta dos primeiros, os ascendentes na ordem de sua proximidade

Quando o pai for ausente ou não tiver possibilidades de arcar satisfatoriamente com a obrigação alimentar, os avôs poderão ser chamados para integrar o pólo passivo (obrigação subsidiária).

Nesse sentido, explica Carlos Roberto Gonçalves:

"O filho somente pode pedir alimentos ao avô se faltar o pai ou se, existindo, não tiver condições econômicas de efetuar o pagamento. Tem a jurisprudência proclamado, nessa linha, que a admissibilidade da ação contra os avós dar-se-á na ausência ou absoluta incapacidade dos pais.

Entende-se por ausência: a) aquela juridicamente considerada (CC, art.22); b) desaparecimento do genitor obrigado, estando ele em local incerto e não sabido (ausência não declarada judicialmente); e c) morte. A incapacidade do principal obrigado pode consistir: a) na impossibilidade para o exercício da atividade laborativa decorrente de estado mórbido, por doença ou deficiência; b) na reconhecida velhice incapacitante; c) na juventude não remunerada pelo despreparo ou incapacidade para o exercício de atividade rentável; d) na prisão do alimentante em face da prática de delito, enquanto durar a pena." 55

Salienta-se, nessa hipótese, que a má vontade do pai em prestar alimentos, quando este tem condições para o trabalho e está presente, pode ser considerada

\footnotetext{
${ }^{54}$ LOUZADA, Ana Maria Gonçalves. Op. cit. p. 33 e 34

${ }^{55}$ GONÇALVES, Carlos Roberto. op. cit. p. 497 e 498.
} 
escusa. Assim, seria injustificável que os avôs figurassem de pronto no pólo passivo. Neste caso, primeiro devem ser utilizados os meios de coerção.

Algumas considerações acerca da obrigação alimentar dos avôs:

1. Ana Maria Gonçalves Louzada traz uma corrente que entende, “equivocadamente" segunda a autora, que se um dos pais tem condições de pagar alimentos aos filhos e o outro não, os avôs não ficariam responsáveis pelo pagamento de pensão alimentícia aos netos, pois um dos genitores poderia mantê-los sozinho. Por isso, se o pai está desempregado e a mãe possui uma carreira profissional, não seria possível pleitear alimentos dos avôs. Afinal, a obrigação dos avôs é sucessiva, subsidiária e complementar. Se a genitora possui condições de arcar com todo encargo sozinha, afastada estaria a necessidade de acionar os avôs. A crítica que se faz a essa corrente é que desta forma estar-se-ia punindo a genitora pela sua projeção em seu trabalho. Por isso, defende Ana Maria Gonçalves Louzada que:

“A obrigação alimentar é de ambos os pais, e, se o genitor não ganha o suficiente para a mantença dos filhos, necessário se mostra a busca da verba em caráter complementar dos avôs, pois, caso assim não fosse, estar-se-ia punindo a genitora pela sua projeção em seu trabalho, o que não é razoável." 56

Por fim, esclarece Ana Maria Gonçalves Louzada:

“A obrigação avoenga é subsidiária, complementar, não se traduzindo na mesma obrigação originária dos genitores. Assim, observado o poder econômico dos avôs, o pensionamento deve ser de tal monta que represente para eles um valor que não os onere demasiadamente, tendo em vista que a referida quantia representa apenas um mero complemento à pensão alimentícia que deveria ser paga pelo genitor aos filhos." 57

Quanto a essa corrente que afasta os avôs do pólo passivo quando um dos pais tem condições de manter a prole, Maria Berenice Dias demonstra seu inconformismo. Observe:

"De maneira surpreendente, a tendência da jurisprudência tem sido ignorar esses dispositivos legais (art.1696 e $1698 \mathrm{CC} / 02$ ), sob o seguinte fundamento: a obrigação é dos pais. Na omissão de um dos pais, o ônus passa para o outro. Somente se ambos os genitores não tem condições de prover o sustento dos filhos é que se invoca a responsabilidade dos avôs. Segundo esse raciocínio, está se impondo ao genitor que tem o filho em sua companhia, que arque sozinho com o seu sustento. Pelo jeito, basta o guardião estar inserido no mercado de trabalho, ter alguma gratificação profissional ou simplesmente desempenhar atividade que gere algum rendimento, para ser responsável exclusiva pela mantença da prole. Caso o outro genitor não pague alimentos, não pode

\footnotetext{
${ }^{56}$ LOUZADA, Ana Maria Gonçalves. op. cit. p.15

${ }^{57}$ LOUZADA, Ana Maria Gonçalves. op. cit. p.15
} 
se socorrer de mais ninguém. Sequer pode invocar a responsabilidade dos avôs pela mantença dos netos. (...)

Contra clara disposição legal vem sendo afastada a obrigação complementar e subsidiária dos ascendentes. O avô, independente de desfrutar de confortável situação de vida e ter ganhos que permitam com tranqüilidade auxiliar no sustento dos netos, não está sendo chamado a contribuir. Não é reconhecida sua obrigação pelo fato da mãe ter algum tipo de rendimento. Nem sequer se atende ao critério da proporcionalidade entre o salário da guardiã e a situação econômica do avô. Basta a genitora auferir algum renda para afastar a responsabilidade dos ascendentes." 58

Diante disso, por essa interpretação errônea dos dispositivos, conclui Maria Berenice Dias a conseqüência desastrosa de se adotar essa corrente:

"Somente na hipótese da genitora não ter nenhum recurso é que se invoca a responsabilidade subsidiária e complementar do avô. Mas, se a mãe tem algum ganho, para acioná-lo, é necessário que abandone seu trabalho ou qualquer atividade que the assegure rendimentos." 59

Por todo o exposto, Maria Berenice Dias se demonstra contra essa corrente.

2. Ressalva a ser feita em relação ao quantum da obrigação subsidiária dos avôs

Ana Maria Gonçalves Louzada explica que a quantia a ser determinada aos avôs não pode ser a mesma que a que seria devida pelos pais. Ainda, o padrão de vida dos netos não deve ser espelhado na condição social dos avôs, mas na de seus pais. Isso ocorre porque a obrigação alimentar dos avôs não decorre do poder familiar, mas sim do parentesco. Tendo em vista que o padrão de vida dos filhos é determinado e proporcionado pelos pais como componente do poder familiar, não poderia ser espelhado nos avôs. Fora essa consideração, a autora ressalta a atenção que se deve ter a possibilidade dos avôs em arcar com a obrigação. ${ }^{60}$

c) Na falta de ascendentes, são convocados os descendentes (filhos netos, bisnetos e etc) conforme a ordem de sucessão prevista no art.1697 do código civil

Quanto à possibilidade do pai cobrar alimentos do filho, Carlos Roberto Gonçalves faz uma ponderação:

\footnotetext{
${ }^{58}$ DIAS, Maria Berenice. Op. cit. p.14 e 15

${ }^{59}$ DIAS, Maria Berenice. Op. cit. p.17

${ }^{60}$ LOUZADA, Ana Maria Gonçalves. Op. cit. p.52 e 53
} 
“Já se decidiu (TJRS, AP. 70.013.502.331, 7ª Câm. Cív., rel. Dês Berenice Dias, j.15-22006) que não tem direito de pedir alimentos aos filhos o pai que, embora alegando idade avançada e desemprego e invocando o dever de solidariedade familiar, comprovadamente abandonou a família, sem manter com ela qualquer contato por mais de dezoito anos. Salientou-se que tal dever é uma via de mão dupla, ou seja, merecer solidariedade implica também ser solidário.” 61

Em relação aos netos, cabe a mesma ponderação feita em relação aos avôs. Nesse sentido, preciso seguir a ordem preferência, cobra-se primeiro do filho. Somente se este for ausente ou impossibilitado de exercer a obrigação por completo, cabe ação contra os netos. Da mesma forma, ação contra os bisnetos, passando antes pelos filhos e os netos.

d) Os irmãos, unilaterais ou bilaterais, sem distinção ou preferência $\left(\operatorname{art} .227 \S 6^{\circ} \mathrm{CF}\right)$

Conforme o artigo 1697 do código civil, somente na falta de ascendentes e descendentes a obrigação alimentar deverá recair sob os irmãos (germanos ou unilaterais, sem distinção).

Considerações acerca dos colaterais:

1. Não há inconstitucionalidade no uso dos adjetivos germanos ou unilaterais. A doutrina mais acertada entende que a lei tão somente pretendeu detalhar. ${ }^{62}$ Segundo Ana Maria Gonçalves Louzada:

"O único raciocínio plausível da dicção do art.1697, ao sublinhar que o dever alimentar cabe tanto aos irmãos germanos quanto aos unilaterais, seria porque em relação ao direito sucessório há distinção no recebimento da herança caso o irmão seja germano ou não, nos termos do art.1841 CC." 63

Todavia, há quem entenda que os irmãos germanos deveriam ser chamados primeiro a prestar a obrigação já que, além do maior grau de parentesco, desfrutam de melhor tratamento na ordem de sucessão. Admitir essa segunda posição implicaria em estabelecer mais uma classe distinta na ordem preferencial. $^{64}$

2. Importante destacar que o direito aos alimentos atinge somente os colaterais até o segundo grau, isto é, somente atinge os irmãos (doutrina

\footnotetext{
${ }^{61}$ GONÇALVES, Carlos Roberto. Op. Cit. p. 499

${ }^{62}$ LOUZADA, Ana Maria Gonçalves. Op. cit. p. 46

${ }^{63}$ LOUZADA, Ana Maria Gonçalves. Op. cit. p. 43

${ }^{64}$ LOUZADA, Ana Maria Gonçalves. Op. cit. p. 44
} 
majoritária). Ao revés, o direito sucessório considera para fins de sucessão legítima os colaterais até o quarto grau (CC, art.1839).

Nesse sentido, não é possível pleitear alimentos de tios ou sobrinhos. Da mesma forma, decidiu o STJ conforme transcrição feita por Carlos Roberto Gonçalves:

"Posicionando-se a maioria doutrinária no sentido de descabimento da obrigação alimentar do tio em relação ao sobrinho, é de afastar-se a prisão do paciente.” ${ }^{65}$

O STJ fala em maioria doutrinária, porque conforme assevera Ana Maria Gonçalves Louzada, há divergência quanto ao tema. Alguns doutrinadores, franca minoria, entendem que a obrigação alimentar seria estendida a todos os parentes, assim entendido os colaterais até $4^{\circ}$ grau (art.1592 CC). ${ }^{66}$ Nessa linha, está Ana Maria Gonçalves Louzada que entende ser razoável e plausível estender a abrangência do pensionamento alimentar aos tios, sobrinhos e primos. O fundamento para quem defende essa corrente é de que o artigo 1697 do Código Civil fala tão somente em parentes. ${ }^{67}$

Quem defende a corrente no sentido da impossibilidade dos tios, sobrinhos e primos figurar como obrigados, alega que o código civil em seus artigos 1696 e 1697 foi preciso ao limitar a obrigação aos parentes colaterais até o segundo grau. No mais, o fato do art.1694 referir-se genericamente a parentes foi pura técnica legislativa para impedir que o artigo ficasse demasiadamente longo desnecessariamente, tendo em vista que os artigos 1696 e 1697 definiriam os graus de parentesco. Por fim, é aparente a incoerência do código, que prevê no direito alimentar a linha colateral até o segundo grau e no sucessório até o quarto, porque os institutos não se confundem. ${ }^{68}$

Para melhor dimensionar o posicionamento de Ana Maria Gonçalves Louzada, necessária a transcrição de alguns trechos de sua obra:

"Trazer a lei algumas explicitações quanto à obrigação entre ascendentes e descendentes, bem como detalhar o dever de irmãos, não exclui os demais parentes do encargo alimentar. O silêncio não significa que os demais parentes tenham sido excluídos do dever de pensionar. Os encargos alimentares seguem os preceitos gerais: na falta dos parentes mais próximos são chamados os mais remotos, começando pelos

\footnotetext{
${ }^{65}$ GONÇALVES, Carlos Roberto. Op. Cit. p. 500

${ }^{66}$ LOUZADA, Ana Maria Gonçalves. Op. cit. p. 32

${ }^{67}$ LOUZADA, Ana Maria Gonçalves. Op. cit. p. 47

${ }^{68}$ LOUZADA, Ana Maria Gonçalves. Op. cit. p. 46
} 
ascendentes, seguidos dos descendentes. Portanto, na falta dos pais, avós e irmãos, a obrigação passa aos tios, tios-avós, depois aos sobrinhos, sobrinhos-netos e, finalmente, aos primos. (...)

Vale citar o exemplo didático e esclarecedor de Maria Berenice Dias: dispondo de patrimônio, mas não de condições de prover a própria subsistência, alguém que não tenha pais, filhos ou irmãos não poderia requerer alimentos aos demais parentes, ou seja, tios, sobrinhos ou primos. Vindo o desafortunado a morrer de fome, seus bens seriam entregues exatamente aos parentes que não lhe deram assistência por falta de dever legal." 69

Em suma, a ordem preferencial para figurar no pólo passivo da ação de alimentos será:

a) Cônjuge ou companheiro (se houver);

b) Ascendentes, sendo que os mais próximos devem ser chamados primeiro (a obrigação dos parentes em linha reta é infinita);

c) Descendentes, sendo que os mais próximos devem ser chamados primeiro (a obrigação dos parentes em linha reta é infinita);

d) Colaterais até o segundo grau: irmãos sem distinção.

\subsubsection{Quem pode pleitear alimentos}

a) Questão do nascituro

O objetivo deste trabalho consiste exatamente em tratar da questão do nascituro. Por isso, maiores explicações serão desenvolvidas nos próximos capítulos que se propõem a tratar das teorias sobre o início da personalidade jurídica e da lei que disciplinou a matéria e suas controvérsias.

A título de introdução no assunto Carlos Roberto Gonçalves expõe o entendimento de YUSSEF CAHALI no sentido de que o nascituro não poderia ser titular da pretensão alimentícia. Para este autor, somente poderia o nascituro receber alimentos pela via indireta através da pensão entregue a esposa. Em relações extrapatrimoniais, nas quais não cabe pensão à mãe, não haveria como o nascituro receber qualquer auxílio. ${ }^{70}$

Em relação a esse entendimento, é possível afirmar que a Lei 11.804/2008 é contrária. Afinal, a referida lei, confere direitos de propor ação alimentar pela via direta para cobrir as despesas da gestação do nascituro (art.2 ${ }^{\circ}$ Lei 11.804/2008).

\footnotetext{
${ }^{69}$ LOUZADA, Ana Maria Gonçalves. Op. cit. p. 47 e 48

${ }^{70}$ GONÇALVES, Carlos Roberto. Op. Cit. p. 495
} 
Além disto, a lei admite que a mãe pleiteie alimentos sem necessariamente comprovar vínculos matrimoniais. Basta que haja indícios de paternidade para que a ação possa ser proposta (art. $6^{\circ}$ Lei $\left.11.804 / 2008\right)$.

b) Parentes em linha reta e colaterais até segundo grau, cônjuges e companheiros que necessitem

Tendo em vista que a obrigação alimentar é recíproca, os mesmos legitimados a prestar a obrigação alimentar, são legitimados a recebê-la caso venham a necessitar. Conforme explicado ao longo do trabalho, a obrigação alimentar deve atender o binômio da necessidade do alimentado e a possibilidade do alimentando; ainda, constitui um direito-dever que não é simultâneo, mas se altera de acordo com esses pressupostos.

\section{Ação de alimentos}

\subsection{Linhas Gerais Importantes}

a) Foro Competente

Ações que versem sobre direito pessoal, o foro seria o do domicílio do réu (art.94 CPC). Todavia, por se tratar de pleito de alimentos, o foro competente é o do domicílio do alimentando (art.100, II CPC). Isso ocorre porque sendo regra especial, prevalece sobre a regra geral.

Importante lembrar que se a ação for interposta em foro distinto e o alimentando não se opuser através da apresentação da exceção de incompetência, haverá prorrogação da competência tendo em vista ser esta relativa. A faculdade de escolha de foro é do alimentando e não do alimentante.

b) Reconvenção

Importante salientar que as ações alimentares que tramitam pelo rito especial não admitem reconvenção. Afinal, o rito especial estabelecido pela lei de alimentos não permite dilação probatória. Por outro lado, se a ação tramitar pelo rito ordinário, a reconvenção será perfeitamente possível nos termos dos artigos 299 e 315 do CPC. 


\subsection{Ação de Alimentos pelo Rito Especial}

Com o intuito de tornar mais célere e efetiva a prestação alimentar, editouse a Lei ${ }^{\circ} 5.478 / 68$ que estabelece um procedimento especial. Para fazer uso desse rito especial é necessário apresentar prova preconstituída acerca da relação de parentesco, de ser cônjuge ou companheiro. Caso não seja possível apresentar tal prova, o alimentando deverá se valer do rito ordinário.

Em relação a essa assertiva, demonstra Ana Maria Gonçalves Louzada que a jurisprudência tem admitido a adoção do rito célere, mesmo que ainda não declarada em juízo à união estável, desde que nos autos já possua indícios fortes de que efetivamente as partes conviveram por certo tempo e mantinham relacionamento afetivo capaz de configurar a união estável. ${ }^{71}$ Portanto, para que possa ser adotado o rito especial, nesse caso, a peça deve vir acompanhada de documento a indicar a verossimilhança da união estável. ${ }^{72}$

\subsubsection{Alimentos Provisórios}

Conforme explicado neste trabalho, os alimentos provisórios são fixados no despacho inicial proferido na ação de alimentos pelo rito especial, dependem de prova preconstituída da existência de obrigação alimentar (parentesco, casamento ou união estável).

A disciplina legal dos alimentos provisórios está no art. $4^{\circ}$ da Lei 5.478/68. Assim, ao despachar o pedido, o juiz deve fixar desde logo os alimentos provisórios a serem pagos pelo devedor, salvo se o credor expressamente declarar que deles não necessita.

Em relação ao texto legal, leciona Carlos Roberto Gonçalves:

"Malgrado a ambigüidade do texto, o juiz não deve fixar de oficio os alimentos provisórios, mas somente se o interessado o requerer. (CPC, art. $\left.2^{\circ}\right) " 73$

Importante salientar que os alimentos provisórios também se sujeitam a cláusula rebus sic stantibus, isto é, poderão ser modificados ao longo do processo quando houver mudança na situação fática que os determinou. Nesse caso, o

\footnotetext{
${ }^{71}$ LOUZADA, Ana Maria Gonçalves. op. cit. p. 121

${ }^{72}$ LOUZADA, Ana Maria Gonçalves. op. cit. p. 122

${ }^{73}$ GONÇALVES, Carlos Roberto. op. cit. p. 506
} 
pedido de revisão será processado em apartado conforme o art. $13 \S 1^{\circ}$ da Lei de Alimentos.

\subsubsection{Termo Inicial}

A maioria dos julgados considera como termo inicial a data da citação. Ana Maria Gonçalves Louzada discorda desse entendimento. Para a autora, os alimentos provisórios devem ter início na data em que forem fixados tendo em vista sua estreita ligação com a sobrevivência. ${ }^{74}$

\subsubsection{Quantum}

A prova da situação econômica cabe ao réu, isto é, há inversão do ônus da prova na ação de alimentos cabendo ao réu provar que seus ganhos estão aquém dos declarados pelo autor na inicial. Se assim não o fizer, os alimentos serão mantidos, conforme pleiteados pelo autor, ou, até majorados, segundo a análise dos pressupostos feita pelo magistrado.

Não constitui julgamento ultra petita a fixação dos alimentos acima do postulado na peça exordial. Afinal, o juiz irá pautar sua decisão segundo seu convencimento acerca da possibilidade do alimentante e da necessidade do alimentando. Nesse sentido, Carlos Roberto Gonçalves e Ana Maria Gonçalves Louzada, respectivamente:

\footnotetext{
"As prestações de alimentos são dívidas de valor e não de quantia certa. Dessa assertiva resulta que inexiste julgamento ultra petita na fixação dos alimentos, pela sentença, acima dos limites da estimativa do pedido. Este, que se formula na ação de alimentos é de natureza genérica, donde não se adstringir a sentença, necessariamente, ao quantum colimado inicialmente; o arbitramento far-se-á a posteriori quando já informado o sentenciante dos elementos fáticos que integram a equação legal." 75

"Destacamos ainda o fato de que a determinação da quantia a ser paga é fixada pelo magistrado atendendo-se às necessidades do alimentando e as possibilidades do alimentante, independentemente do valor pedido, vale dizer, ainda que o magistrado fixe a pensão alimentícia em valor superior ao pedido, não será considerada decisão extra petita." 76
}

Por fim, caso os alimentos fixados na sentença sejam maiores que os provisórios, o valor retroage a data da citação e o devedor deverá pagar os

\footnotetext{
${ }^{74}$ LOUZADA, Ana Maria Gonçalves. op.cit. p. 122 e 123.

${ }^{75}$ GONÇALVES, Carlos Roberto. op. cit. p.508

${ }^{76}$ LOUZADA, Ana Maria Gonçalves. op. cit. p. 124 e 125
} 
acréscimos. Ao revés, sendo fixados alimentos à menor, como não há repetição na obrigação alimentar, não se pode falar em devolução dos alimentos que o alimentante tiver obtido a mais.

\subsection{Ação de Alimentos pelo Rito Ordinário}

Quando não houver prova preconstituída da obrigação alimentar, o alimentando deverá pleitear alimentos pela via ordinária para possibilitar a colheita das provas devidas. Ainda, é possível cumular pedidos tais como investigação de paternidade cumulada com alimentos. Nesse sentido, leciona Ana Maria Gonçalves Louzada:

\footnotetext{
"Quando o requerente não detiver prova preconstituída de parentesco, casamento ou de que conviveu em união estável com a parte ré, deverá adentrar com o feito alimentar sob o rito ordinário, a fim de que as provas sejam devidamente colhidas, ou incidentalmente, junto às ações de investigação de paternidade e reconhecimento e dissolução de união estável. Nesses casos, os alimentos não serão fixados initio litis, uma vez que prescindem de prova constitutiva de seu direito. Contudo, a partir do momento em que o magistrado entender que há provas nos autos suficientes a ensejar o deferimento da verba alimentar, esses serão desde logo fixados." 77
}

\subsubsection{Alimentos Provisionais}

Nesse caso, em se tratando de ação de alimentos pelo rito ordinário, pode o alimentando formular pedido cautelar, incidente ou antecedente, requerendo alimentos provisionais, ou ainda, requerer tutela antecipada (art.1706 CC; arts. 852 e 273 CPC).

Para que sejam deferidos os alimentos provisionais não é necessária a prova preconstituída, basta que haja indícios de parentesco. Ainda, o deferimento está sujeito a discricionariedade do juiz ao avaliar o fumus boni iuris e o periculum in mora no caso.

\subsection{Ação de Oferta de Alimentos}

A ação de oferta de alimentos está prevista no art.24 da Lei de Alimentos (Lei 5.478/68). O objetivo desta ação é muitas vezes garantir o devedor de alimentos de que os mesmos não serão futuramente estipulados em valor muito maior do que suas possibilidades.

\footnotetext{
${ }^{77}$ LOUZADA, Ana Maria Gonçalves. op. cit. p. 128
} 
O procedimento a ser seguido é o mesmo da lei de alimentos (os alimentos são fixados liminarmente, será marcada audiência, o quantum não está limitado aos termos da ação).

Não se aplica na ação de oferecimento de alimentos o arquivamento da ação por ausência do autor (art. $7^{\circ}$ da lei). Quanto à ausência do réu, há divergência na doutrina. Para alguns, não se pode impor ao réu receber alimentos que por motivos íntimos não deseje receber. Nesse caso, caberia arquivamento. Outra parte da doutrina se posiciona no sentido de que, ausente o réu, como não é possível the impor sanções (revelia e confissão das matérias de fato), haverá a ratificação dos valores fixados provisoriamente. Nesse sentido, a ausência do réu implicaria em presunção de que aceitou aqueles valores.

Pode ocorrer conexão, isto é, tramitar simultaneamente ação de oferta e ação de alimentos. Nesse caso, será preciso determinar o juízo prevento de acordo com as regras processuais (art.103, 106 e 219 CPC).

\subsection{Ação revisional de alimentos}

A ação revisional prescinde de uma ação de alimentos, isto é, para que seja possível a revisão, é necessário que os alimentos já tenham sido fixados de alguma forma. Ainda, para que seja possível o pleito revisional é necessário que tenha ocorrido mudança nos pressupostos da obrigação alimentar (necessidade do alimentando, possibilidade do alimentante). A possibilidade da ação revisional ocorre devido a cláusula rebus sic stantibus contida em toda decisão acerca de alimentos (art.1699 CC).

A ação revisional tem como espécies a ação de majoração, de diminuição e de exoneração.

Conforme o art.13 da lei de alimentos, o disposto na lei será aplicado no que couber as ações de revisão de sentença. Em outras palavras, o rito especial será aplicado às ações revisionais, salvo quando estas necessitarem de ampla dilação probatória.

Importante ressaltar que, nas ações revisionais, o juiz não precisa fixar os novos alimentos (majorados, diminuídos ou exonerados) já no despacho inicial. 
Assim, caso o pedido seja de diminuição e a sentença julgue procedente, o novo valor passará a ter vigência a partir da sentença, isto é, não irá retroagir porque os alimentos são irrepetíveis. Se o pedido for de majoração, julgado procedente, o novo valor retroage à citação atingindo as verbas pagas à menor.

Alguns comentários interessantes acerca do tema feitos por Carlos Roberto Gonçalves merecem ser registrados, a saber:

"O desemprego não tem sido considerado causa de exoneração definitiva da obrigação de prestar alimentos. Ao reverso, tem-se decidido que o desemprego ocasional do alimentante não incapacita a prestação alimentícia para o efeito de exoneração, podendo apenas justificar inadimplência transitória." 78

"Admite-se a fixação de alimentos provisórios em ação revisional de alimentos, porém sempre em razão de circunstâncias excepcionais, quando, por exemplo, os alimentos anteriormente fixados se mostram excessivamente irrisórios." 79

\footnotetext{
${ }^{78}$ GONÇALVES, Carlos Roberto. op. cit. p. 512
}

${ }^{79}$ GONÇALVES, Carlos Roberto. op. cit. p. 513 


\section{ASPECTOS MATERIAIS DA LEI N¹1.804/2008}

\section{Personalidade Civil e Direitos da Personalidade}

\subsection{Personalidade e Pessoa Natural}

Conforme lição de Carlos Roberto Gonçalves:

"Todo aquele que nasce com vida torna-se uma pessoa, ou seja, adquire personalidade. Esta é, portanto, qualidade ou atributo do ser humano. Pode ser definida como aptidão genérica para adquirir direitos e contrair obrigações ou deveres na ordem civil." 80

Portanto, a personalidade civil (aptidão para adquirir direitos e contrair obrigações) está diretamente associada com o nascimento com vida (CC, art. $\left.2^{\circ}\right)$. Desse modo, acrescenta Caio Mario da Silva Pereira ${ }^{81}$, esta não depende da consciência ou vontade do indivíduo. Em outros termos, não importa se a pessoa em questão é criança ou deficiente mental, ambos têm personalidade civil. É o que se denomina pessoa natural, física.

Além das pessoas, o direito reconhece a aptidão para adquirir direitos e contrair obrigações a entes morais (sociedades, associações, fundações). É o que se denomina pessoa jurídica. Quanto a outros seres vivos, por exemplo, animais, embora desfrutem de proteção, não possuem personalidade.

Dito isto, é preciso diferenciar capacidade de direito/gozo/aquisição da capacidade de exercício/ação/fato. A primeira estende-se a todas as pessoas, independente da idade ou discernimento mental. A segunda se traduz na aptidão para exercer sozinho os atos da vida civil.

Pelo exposto, há íntima relação entre personalidade e capacidade. Segundo Carlos Roberto Gonçalves, personalidade e capacidade se completam de forma que a privação da capacidade implica a frustração da personalidade. $^{82}$

\footnotetext{
${ }^{80}$ GONÇALVES, Carlos Roberto. Direito Civil Brasileiro: Parte Geral, v.1. $7^{\text {a }}$ Ed. rev. e atual. - São Paulo: Saraiva, 2009. p. 70.

${ }^{81}$ PEREIRA, Caio Mario da Silva. Instituições de direito Civil: Introdução do direito Civil. Teoria Geral de Direito Civil, v.1. 20 a ed. rev. e atual. - Rio de Janeiro: Forense, 2004. p. 214

${ }^{82}$ GONÇALVES, Carlos Roberto. Direito Civil Brasileiro: Parte Geral, v.1. $7^{\text {a }}$ Ed. rev. e atual. - São Paulo: Saraiva, 2009. p. 72
} 


\subsection{Começo da Personalidade}

\subsubsection{Teorias sobre a personalidade civil (até a consagração dos direitos do nascituro pela L.11.804/2008)}

Há divergência doutrinária quanto ao início da personalidade. Principais teorias:

a) Teoria Natalista: a personalidade tem início a partir do nascimento com vida (art. $2^{\circ} \mathrm{CC}$, primeira parte). Antes disto, haveria somente uma expectativa de direito por parte do nascituro que somente se concretizará se vier a nascer com vida. Assim, apenas o nascimento com vida é capaz de conferir personalidade. Nesse sentido, leciona Caio Mario da Silva Pereira:

"Antes do nascimento o feto ainda não é uma pessoa, mas, se vem à luz como um homem capaz de direitos, a sua existência, no tocante aos seus interesses, retrotrai ao momento de sua concepção." ${ }^{83}$

A lei ao resguardar os direitos do nascituro não the estaria atribuindo personalidade. Os direitos do nascituro de que trata a lei são os que ele possivelmente terá se vier a nascer com vida. Tais direitos estão descritos taxativamente no texto legal. ${ }^{84}$

Ainda, o nascituro, semelhante ao que ocorria no direito romano, é encarado como sendo parte das vísceras da mãe. O nascimento, ao permitir a separação dos corpos, concede ao nascituro o status de pessoa. ${ }^{85}$

Para os que defendem essa teoria, seria impossível o pleito alimentar pelo nascituro. Afinal, o nascituro não detém personalidade e não há como o alimento ser concedido diretamente a este porque é preciso a mãe de intermediária. Nesse sentido, Anderson Evangelista ressalta o fundamento da teoria que nega os alimentos ao nascituro:

"O nascituro não consegue receber o alimento dado pelo pai, posto que se alimenta apenas com o material dispensado pelo interior do corpo de sua mãe." 86

\footnotetext{
${ }^{83}$ PEREIRA, Caio Mario da Silva. Instituições de Direito Civil: Introdução do Direito Civil. Teoria Gral de Direito Civil, v. 1. $20^{\mathrm{a}}$ ed. rev. e atual. - Rio de Janeiro: Forense, 2004. p. 218

${ }^{84}$ FILHO, José Roberto Moreira. O direito Civil em face das novas técnicas de reprodução assistida. Jus Navigandi, Teresina, ano7, n. 55, 1 mar. 2002. Disponível em: http://jus.uol.br/revista/texto/2747 Acesso em: 29 abr. 2011.

${ }^{85}$ FILHO, José Roberto Moreira. O direito Civil em face das novas técnicas de reprodução assistida. Jus Navigandi, Teresina, ano7, n. 55, 1 mar. 2002. Disponível em: http://jus.uol.br/revista/texto/2747 Acesso em: 29 abr. 2011.
} 
Dito isto, Carlos Roberto Gonçalves explana que YUSSEF CAHALI não admitia que o nascituro fosse titular de pensão alimentícia, mas reconhecia que, indiretamente, poderia recebê-los por pensão deferida à esposa. ${ }^{87}$

Anderson Evangelista acrescenta que os defensores dessa corrente argumentam que quando ocorre nascimento sem vida é feito registro, mas este é feito apenas com a descrição acerca do nascimento sem vida, não atribuindo nome (direito da personalidade) ao natimorto. ${ }^{88}$

Segundo Caio Mario, essa é teoria que predominou no seio do novo código civil no art. $2^{\circ}$.

b) Teoria da Personalidade Condicional (é uma teoria intermediária):

Por essa teoria, o nascituro teria personalidade desde a sua concepção, porém esta se sujeitaria a uma condição suspensiva, qual seja nascer com vida. Em outras palavras, traz a idéia de uma pessoa condicional, cujos direitos estão em estado potencial. Se a condição não vier a ser implementada, não haverá personalidade. Assim, nascendo com vida, a personalidade retroagirá a data da concepção. Ao revés, se não nascer ou for natimorto, a condição não terá sido implementada e não haverá personalidade jurídica.

Maria Helena Diniz diferencia os direitos personalíssimos dos direitos patrimoniais. Segundo a jurista, os direitos da personalidade, sem conteúdo patrimonial (ex. direito à vida ou a uma gestação saudável), seriam adquiridos desde a concepção. Por outro lado, os direitos patrimoniais estariam sujeitos ao nascimento com vida (sob condição suspensiva). ${ }^{89}$ Nesse sentido, a transcrição trazida por Carlos Roberto Gonçalves acerca do posicionamento da jurista:

"Poder-se-ia até mesmo afirmar que na vida intra-uterina e na vida extra-uterina tem o embrião, personalidade jurídica formal, no que atina aos direitos personalíssimos, visto ter carga genética diferenciada desde a concepção, seja ela in vivo ou in vitro, passando a ter personalidade jurídica material, alcançando os direitos patrimoniais, que se

\footnotetext{
86 EVANGELISTA, Anderson. Feto tem direito a pensão alimentícia. In: Âmbito Jurídico, Rio Grande, 53, 31/05/2008 [Internet]. Disponível em: http://www.ambitojuridico.com.br/site/index.php?n_link=revista_artigos_leitura\&artigo_id=2841 Acesso em: 29 abr. 2011.

${ }^{87}$ GONÇALVES, Carlos Roberto. Direito Civil Brasileiro: Direito de Família, v. 6. $6^{\text {a }}$ Ed. rev. e atual. São Paula: Saraiva, 2009. p. 495

${ }^{88}$ EVANGELISTA, Anderson. Feto tem direito a pensão alimentícia. In: Âmbito Jurídico, Rio Grande, 53, 31/05/2008 [Internet]. Disponível em: http://www.ambitojuridico.com.br/site/index.php?n_link=revista_artigos_leitura\&artigo_id=2841 Acesso em: 29 abr. 2011.

${ }^{89}$ GONÇALVES, Carlos Roberto. Direito Civil Brasileiro: Parte Geral, v.1. $7^{\mathrm{a}}$ Ed. rev. e atual. - São Paulo: Saraiva, 2009. apud. p. 82
} 
encontravam em estado potencial, somente com o nascimento com vida (CC, art.1808 $\S 3^{\circ}$ ). Se nascer com vida, adquire personalidade jurídica material, mas se tal não ocorrer nenhum direito patrimonial terá." 90

Portanto, a personalidade para a teoria da personalidade condicional não é adquirida plenamente no momento da concepção. Afinal, certos direitos, notadamente os de caráter patrimonial, estariam condicionados ao nascer com vida para atingirem sua plenitude.

Exemplificando: o direito à vida é adquirido desde a concepção. Seria contraditório, conforme ressalta artigo do IBDFAM "da titularidade dos alimentos gravídicos: uma (re) visão das teorias do início da personalidade", considerar que o nascituro tenha mera expectativa deste direito, vindo somente a adquiri-lo após o nascimento com vida. Caso contrário, não haveria fundamento a punição do aborto, eis que não haveria um direito constituído, mas mera expectativa. $^{91}$

Em suma, por essa teoria, direitos personalíssimos, sem cunho patrimonial, seriam garantidos em sua plenitude desde a concepção; direitos com cunho patrimonial estariam sob condição suspensiva.

Admitindo-se a existência da personalidade a partir da concepção, admissível seria o pleito aos alimentos pelo nascituro.

c) Teoria Concepcionista

Segundo essa teoria, a personalidade se inicia desde a concepção, ou seja, antes do nascimento. Nesse sentido, aduz CHINELATO ALMEIDA em trecho retirado da obra de Carlos Roberto Gonçalves:

“A personalidade do nascituro não é condicional; apenas certos efeitos de certos direitos dependem do nascimento com vida, notadamente os direitos patrimoniais materiais, como a doação e herança." 92

O que a autora pretende dizer é que o nascituro é titular da personalidade desde a concepção, seja de direitos personalíssimos, seja de direitos patrimoniais.

\footnotetext{
${ }^{90}$ GONÇALVES, Carlos Roberto. Direito Civil Brasileiro: Parte Geral, v.1. $7^{\mathrm{a}}$ Ed. rev. e atual. - São Paulo: Saraiva, 2009. apud. p. 82

${ }^{91}$ SANTOS, Marina Alice de Souza. Da titularidade dos alimentos gravídicos: uma (re) visão das teorias do inicio da personalidade. IBDFAM. 30 mar. 2010. Disponível em: http://www.ibdfam.org.br/?artigos\&artigo=599 Acesso em: 29 abr. 2011

${ }^{92}$ GONÇALVES, Carlos Roberto. Direito Civil Brasileiro: Parte Geral, v.1. $7^{\text {a }}$ Ed. rev. e atual. - São Paulo: Saraiva, 2009. apud. p. 81
} 
Todavia, em se tratando de direitos patrimoniais, somente se operariam os efeitos se ocorre nascimento com vida. Nesse sentido, artigo publicado no Jus Navigandi elaborado por João Freitas de Castro Chaves, a saber:

"Para Silmara Chinelato, defensora desta idéia, a personalidade do nascituro é incondicional, não dependendo de nenhum evento subseqüente, estando seus direitos personalíssimos (vida, liberdade, saúde) garantidos. No entanto, certos efeitos de certos direitos (como os patrimoniais) dependem do nascimento com vida. A titularidade dos direitos não seria discutida, havendo apenas incapacidade. Já em relação aos direitos patrimoniais, o nascimento sem vida funcionaria tão só como condição resolutiva. Baseado nesta linha de argumentação, o professor Silvio Neves Baptista aponta os direitos a receber doação e herança como existentes desde a concepção, mas dependentes do nascimento com vida para a produção de efeitos." 93

Portanto, a personalidade não se discute, existe desde a concepção. O que é passível de alteração são os efeitos de certos direitos. Nesse sentido, cabe a transcrição de trecho do artigo publicado junto ao IBDFAM:

"Apenas certos efeitos de certos direitos, isto é, os direitos patrimoniais materiais, como a herança e a doação, dependem do nascimento com vida. A plenitude da eficácia desses direitos fica resolutivamente condicionada ao nascimento sem vida. O nascimento com vida, enunciado positivo de condição suspensiva, deve ser entendido ao reverso, como enunciado negativo de uma condição resolutiva, isto é, o nascimento sem vida, porque o código civil, bem como outros de seus dispositivos, reconhecem direitos (não expectativas de direitos) e estado ao nascituro, não do nascimento com vida, mas desde a concepção." 94

Por fim, o mesmo artigo ${ }^{95}$ traz como lição de Silmara J.A. Chinelato e Almeida que os direitos do nascituro elencados pelo código civil não são taxativos. Cita como fundamento o fato do art. $2^{\circ}$ ter feito alusão genérica a estes. Assim, para os que defendem a teoria concepcionista, o nascituro teria outros direitos, tal como o direito de pleitear alimentos.

Dentre os argumentos utilizados pelos defensores dessa teoria está a tipificação do crime de aborto no título referente aos "Crimes contra a pessoa". Ainda, se o nascituro possui direitos legalmente assegurados é porque se considera como sendo pessoa. Afinal, somente as pessoas são sujeitos de direito.

93 CHAVES, João Freitas de Castro. Responsabilidade civil por dano causado ao nascituro: possibilidades de reparação no direito brasileiro. Jus Navigandi, Teresina, ano 5, n. 46, 1 out. 2000. Disponível em: <http://jus.uol.com.br/revista/texto/524>. Acesso em: 29 abr. 2011.

${ }^{94}$ SANTOS, Marina Alice de Souza. Da titularidade dos alimentos gravídicos: uma (re) visão das teorias do inicio da personalidade. IBDFAM. 30 mar. 2010. Disponível em: http://www.ibdfam.org.br/?artigos\&artigo=599 Acesso em: 29 abr. 2011.

95 SANTOS, Marina Alice de Souza. Da titularidade dos alimentos gravídicos: uma (re) visão das teorias do inicio da personalidade. IBDFAM. 30 mar. 2010. Disponível em: http://www.ibdfam.org.br/?artigos\&artigo=599 Acesso em: 29 abr. 2011. 
Por fim, vários dos direitos assegurados ao nascituro não estão condicionados ao nascimento com vida. Assim, o nascituro adquire esses direitos como se pessoa fosse e não como mera expectativa (ex. direito a vida, integridade física, reconhecimento de filiação). ${ }^{96}$

Anderson Evangelista explica que para essa corrente, quando o nascituro nasce sem vida e é registrado, isso geraria personalidade civil. ${ }^{97}$

Os defensores dessa teoria afirmam que esse foi o verdadeiro posicionamento do legislador no código civil, vislumbrado na segunda parte do $\operatorname{art.} 2^{\circ} .98$

O nascituro, como detentor de uma nova vida, estaria apto para adquirir personalidade.

Segundo Anderson Evangelista, no artigo "feto tem direito a pensão alimentícia" 99 , a adoção da corrente importa para responder a pergunta se o feto teria ou não direito aos alimentos. Afinal, para a corrente natalista, não se pode conceder direitos se não há personalidade. Ao revés, para a corrente condicionalista, tendo o nascituro, personalidade, ainda que sujeita a condição suspensiva, desde a concepção, o pleito seria perfeitamente possível. Quanto à teoria concepcionista, também seria perfeitamente possível o pleito alimentar uma vez que a personalidade se adquire integralmente desde a concepção (apenas certos efeitos de certos direitos estariam condicionados ao nascimento com vida).

A edição da lei de alimentos gravídicos surge para por um fim a controvérsia ao admitir o pleito alimentar aos nascituros. $\mathrm{O}$ artigo $2^{\circ}$ da lei 11.804/2008 garante a concessão de alimentos para cobrir despesas que vão da concepção ao parto. Nesse sentido, ao que parece, a postura adotada pela lei se

\footnotetext{
${ }^{96}$ FILHO, José Roberto Moreira. O direito Civil em face das novas técnicas de reprodução assistida. Jus Navigandi, Teresina, ano7, n. 55, 1 mar. 2002. Disponível em: http://jus.uol.br/revista/texto/2747 Acesso em: 29 abr. 2011.

${ }^{97}$ EVANGELISTA, Anderson. Feto tem direito a pensão alimentícia. In: Âmbito Jurídico, Rio Grande, 53, 31/05/2008 [Internet]. Disponível em: http://www.ambitojuridico.com.br/site/index.php?n_link=revista_artigos_leitura\&artigo_id=2841 Acesso em: 29.04

${ }_{98}$ SANTOS, Marina Alice de Souza. Da titularidade dos alimentos gravídicos: uma (re) visão das teorias do inicio da personalidade. IBDFAM. 30 mar. 2010. Disponível em: http://www.ibdfam.org.br/?artigos\&artigo=599 Acesso em: 29 abr. 2011.

${ }^{99}$ EVANGELISTA, Anderson. Feto tem direito a pensão alimentícia. In: Âmbito Jurídico, Rio Grande, 53, 31/05/2008 [Internet]. Disponível em: http://www.ambitojuridico.com.br/site/index.php?n_link=revista_artigos_leitura\&artigo_id=2841 Acesso em: 29 abr. 2011.
} 
aproxima da teoria concepcionista (mais próxima das exigências constitucionais conforme será explanado mais adiante).

\subsubsection{Sistema de Proteção ao nascituro: direitos do nascituro}

\subsubsection{Direito de receber doações}

Segundo o artigo 542 do código civil, é admissível a doação ao nascituro. Tal doação terá eficácia se aceita por seu representante legal.

\subsubsection{Reconhecimento voluntário de filiação}

O artigo 1609, parágrafo único do código civil traz a possibilidade do reconhecimento do filho antes de seu nascimento.

No mesmo sentido, o artigo 26, parágrafo único do Estatuto da criança permite o reconhecimento da filiação antes do nascimento.

\subsubsection{Direito a curatela e representação}

Conforme o artigo 1779 do Código Civil será nomeado curador quando o pai falecer estando grávida a mulher que não detenha poder familiar. Ex.: Quando a mulher grávida é dependente química, alcoólatra.

Não havendo perda do poder familiar, a representação do direito do nascituro será feita pelos pais. Nesse sentido, artigo 877 e 878 do código de processo civil.

\subsubsection{Direito de suceder}

Tratado no artigo 1798 e 1799 do código civil, o nascituro poderá ser contemplado em testamento.

$\mathrm{O}$ artigo 1798 fala em "pessoas já concebidas no momento da abertura da sucessão", ou seja, aplica-se ao nascituro.

\subsubsection{Proteção do Nascituro através da penalização do aborto}

$\mathrm{O}$ código penal tipifica o aborto como crime nos artigos 124 a 128. Deste modo, está a resguardar a vida do nascituro. Ainda, é forte argumento, conforme mencionado quando tratamos do início da personalidade, para corroborar a 
personalidade jurídica do nascituro, uma vez que o crime de aborto foi tipificado dentro do título dos crimes contra a pessoa.

\subsection{Direitos da Personalidade}

Segundo Caio Mario ${ }^{100}$ os direitos da personalidade poderiam ser divididos em dois grupos:

a) Direitos adquiridos: como decorrência do status individual. Existem nos termos e na extensão que o direito lhes conceder.

b) Direitos inatos: que são absolutos (oponíveis erga omnes) e irrenunciáveis (vinculados a pessoa de seu titular). Ex.: direito à vida, integridade física e moral.

\subsubsection{Direito à vida e a integridade física}

O direito à vida é, conforme explicado por Caio Mario, um direito inato do indivíduo e, portanto, um direito absoluto.

$\mathrm{O}$ direito à vida encontra amparo legal na Constituição Federal, no artigo $5^{\circ}$ ("inviolabilidade do direito à vida"), no artigo 227 ("é dever da família, da sociedade e do Estado assegurar à criança, ao adolescente e ao jovem, com absoluta prioridade, o direito à vida"), no Estatuto da Criança e do Adolescente artigo $5^{\circ}$ ("nenhuma criança ou adolescente será objeto de qualquer forma de negligência, discriminação, exploração, violência, crueldade e opressão, punido na forma da lei qualquer atentado, por ação ou omissão, aos seus direitos fundamentais") e artigo $7^{\circ}$ (“a criança e o adolescente têm direito a proteção à vida").

Acerca destes dispositivos, é possível tecer algumas considerações:

A repersonalização do direito civil, a ser explicada no próximo ponto deste trabalho, implica que os dispositivos civis sejam lidos a luz da constituição federal. A Constituição passa a ser o centro do direito.

Portanto, quando a Constituição assegura o direito à vida no artigo $5^{\circ}$, no rol de direitos e garantias fundamentais, lhe atribui o status de cláusula pétrea Geral do Direito Civil, v. 1. 20 Ed. rev. e atual. - Rio de Janeiro: Forense, 2004.. p. 242 
conforme o art. $60, \$^{\circ}$, não podendo este direito ser revogado nem mesmo por emenda.

Diante disto, qualquer que seja a teoria adotada, não se pode negar o direito à vida. Assim, ainda que se considere a teoria natalista, que nega personalidade ao nascituro mas the resguarda certos direitos desde a concepção, certamente o direito à vida deve estar nesse rol. O direito à vida é garantido pela constituição e, em uma interpretação a luz desta, os dispositivos civis também devem garanti-lo.

Trata-se de um direito que independe do nascimento com vida. Pouco importa se a personalidade será adquirida somente pelo nascimento com vida. É certo que o direito à vida é tutelado pelo ordenamento e ninguém discute que o nascituro tenha direito à vida e não mera expectativa.

Nesse sentido, a omissão legislativa quanto ao tema da concessão dos alimentos ao nascituro e a teoria natalista perdem espaço diante da edição da lei de alimentos gravídicos que reconhece, em seu artigo $2^{\circ}$, a possibilidade da concessão de alimentos no período entre a concepção e o parto. Parece, portanto, que a referida lei inovou no campo do direito material ao reconhecer a teoria concepcionista.

\section{Alimentos Gravídicos - Histórico. Evolução Legislativa e Jurisprudencial.}

Conforme ensina Caio Mario da Silva Pereira, no direito romano, a personalidade coincidia com o nascimento. O feto era visto como uma parte da mãe e não uma pessoa, ente ou corpo. Não obstante a isso, seus interesses eram resguardados (muito embora se reconhecesse que o nascimento era requisito para aquisição de direitos) pela aplicação da regra da antecipação presumida de seu nascimento. 101

O direito moderno assenta a regra do início da personalidade no direito romano. Assim, o código civil de 1916 adotou a postura de que a personalidade se iniciaria com o nascimento com vida, resguardados os direitos do nascituro

\footnotetext{
101 PEREIRA, Caio Mario da Silva. Instituições de Direito Civil: Introdução do Direito Civil. Teoria Geral do Direito Civil, v.1. 20ª ed. rev. e atual. - Rio de Janeiro: Forense, 2004. p.216
} 
desde a concepção. Segundo Caio Mario, o mesmo posicionamento foi seguido no Código Civil de 2002. ${ }^{102}$

Pelo exposto, predominava a teoria natalista segundo a qual a personalidade se adquire com o nascimento com vida e, portanto, o nascituro não teria personalidade. Não tendo personalidade, impossível figurar no pólo de uma demanda por alimentos. Conforme mostrado acima, Yussef Cahali admitia somente a hipótese por via indireta quando a mãe tivesse direito à pensão - seja por decorrência do casamento, união estável. Nesse sentido, a jurisprudência anterior a lei 11.804/2008:

UNIÃO ESTÁVEL. ALIMENTOS PROVISÓRIOS. EX-COMPANHEIRA E NASCITURO. PROVA. 1. Evidenciada a união estável, a possibilidade econômica do alimentante e a necessidade da ex-companheira, que se encontra desempregada e grávida, é cabível a fixação de alimentos provisórios em favor dela e do nascituro, presumindo-se este filho das partes. 2. Os alimentos poderão ser revistos a qualquer tempo, durante o tramitar da ação, seja para reduzir ou majorar, seja até para exonerar o alimentante, bastando que novos elementos de convicção venham aos autos. Recurso Provido em parte. ${ }^{103}$

Outro óbice à concessão de alimentos ao nascituro estava na Lei de Alimentos (L. 5478/68). Na referida lei era exigida a comprovação do vínculo parentesco ou da obrigação alimentar. ${ }^{104}$

O art.1694 do Código Civil de 2002 é omisso quanto à possibilidade de o nascituro requerer alimentos. ${ }^{105}$

Existia jurisprudência, embora minoritária, que admitia o pleito alimentar pelo nascituro, a saber:

"FAMÍLIA. INVESTIGAÇÃO DE PATERNIDADE E ALIMENTOS. NATUREZA PERSONALÍSSIMA DA AÇÃO. LEGITIMIDADE ATIVA. DIREITO DO NASCITURO. São legitimados ativamente para a ação de investigação de paternidade e alimentos o investigante, o Ministério Público, e também o nascituro, representado pela mãe gestante" 106

\footnotetext{
102 PEREIRA, Caio Mario da Silva. Instituições de Direito Civil: Introdução do Direito Civil. Teoria Geral do Direito Civil, v.1. . 20ª ed. rev. e atual. - Rio de Janeiro: Forense, 2004. p.218

${ }^{103}$ TJRS - Ag. de Inst. 70017520479 - $7^{\text {a }}$ Câm. Cív. - Rel. Sérgio Fernando de Vasconcellos Chaves - j. em 28.03.2007 - DJ 03.04.2007, citado na obra Direito na Prática: alimentos e ação de alimentos. Manual do operador do direito, de autoria de Marklea da Cunha Ferst, p.58

${ }^{104}$ LOMEU, Leandro Soares. Alimentos Gravídicos: aspectos da lei 11.804/08. IBDFAM. 19 nov. 2008. Disponível em: http://www.ibdfam.org.br/?artigos\&artigo=467 Acesso em: 29 abr. 2011.

${ }^{105}$ LOUZADA, Ana Maria Gonçalves. op. cit. p.39

106 TJMG, Processo no ${ }^{\circ}$ 1.0024.04.377309-2/001(1), Rel. Duarte de Paula, j. 10.03.05, publicação 10.06.05, citado no artigo $O$ Ministério Público e sua atuação em face dos alimentos gravídicos, encontrado no http://www.ampep.com.br/novo/gravdicos.doc acesso: 30 abr. 2011.
} 
Quanto à legitimidade do nascituro, Caio Mario já dizia que, na hipótese de reconhecimento anterior ao nascimento (art. 1609, parágrafo único do $\mathrm{CC}$ ), não se poderia excluir sua legitimidade para a propositura da ação de alimentos. ${ }^{107}$

Apesar de em certos casos ser admitido o deferimento de alimentos ao nascituro, a jurisprudência dominante entendia pela impossibilidade da concessão de alimentos ao nascituro por falta de previsão legal. ${ }^{108}$

A questão que surgia era: ora se o código põe a salvo os direitos do nascituro desde a concepção, como não lhe garantir o direito primordial à vida (não lhe concedendo os alimentos)?

Nesse sentido, Ana Maria Louzada retrata o posicionamento de Pontes de Miranda, a saber:

"Pontes de Miranda já lecionava que a obrigação de alimentos também pode começar antes do nascimento e depois da concepção (art. $2^{\circ}$ e 1696 CC), pois antes de nascer, existem despesas que tecnicamente se destinam a proteção do concebido e o direito seria inferior à vida se acaso recusasse atendimento a tais relações inter-humanas, solidamente fundadas em exigências de pediatria." 109

Com a repersonalização do direito civil decorrente da constitucionalização dos direitos civis instituído pela Constituição Federal de 1988, o direito do nascituro aos alimentos ganha novo impulso. Nesse ponto cabe um resumo do artigo "Direito do nascituro a Alimentos: Uma abordagem civil-constitucional":

$\mathrm{O}$ artigo "direito do nascituro a alimentos: uma abordagem civilconstitucional" 110 relembra que a história do direito sempre foi marcada pela dicotomia entre o direito público e o privado. Assim, no Estado Liberal havia nítido distanciamento entre sociedade civil e Estado. Com o advento das crises capitalistas, foi posto em xeque esse distanciamento entre as sociedades políticas e as sociedades civis de modo que o Estado passa a ser devedor de prestações positivas (postura intervencionista do Estado - Estado Social de Direito).

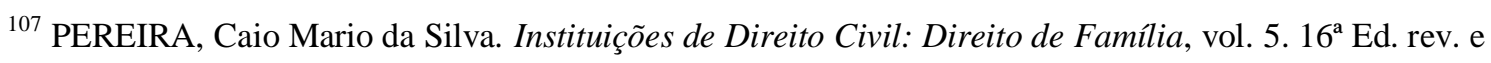
atual. - Rio de Janeiro: Forense, 2007. p. 519.

${ }^{108}$ LOUZADA, Ana Maria Gonçalves. op. cit. p.39

${ }^{109}$ LOUZADA, Ana Maria Gonçalves. op. cit. p.40

${ }^{110}$ GÓES, Jamille Argolo. Direito do nascituro a alimentos. Uma abordagem civil-constitucional. Jus Navigandi, Teresina, ano 15, n.2442, 9 mar. 2010. Disponível em: http://jus.uol.com.br/revista/texto/14464 Acesso em: 11 mar. 2011
} 
correspondendo às novas expectativas constitucionais. Devido a isso, diversas leis esparsas (ECA, CDC) foram editadas para solucionar os novos conflitos. O código civil deixa de ser o único a tratar da matéria para passar a ser o centro, no qual gravitam ao redor diversos microsistemas. ${ }^{111}$

Posteriormente, o Estado Social de Direito foi substituído pelo Estado Democrático de Direito comprometido em dar efetiva realização aos direitos fundamentais. ${ }^{112}$

Todo esse processo de evolução ocasionou a constitucionalização do direito privado que, segundo o artigo em questão, pode ser encarado sob dois aspectos: diversos institutos regulados nos códigos privados passaram a ser disciplinados nas constituições (relevância constitucional das relações privadas) e o comando da interpretação conforme a constituição. ${ }^{113}$

Cristiano Chaves de Farias e Nelson Rosenvald, conforme se infere do artigo, explicam que essa interpretação conforme a constituição deve ser no sentido de realizar uma releitura dos institutos civis. ${ }^{114}$ A constituição, com esse novo modelo de Estado, passa a ser o centro do ordenamento de modo que as questões civis devem ser solucionadas com base nos princípios constitucionais.

Por todo o exposto neste artigo, afirma a autora que a única teoria que se poderia adotar, a partir da Constituição de 1988, seria a concepcionista já que esta é a que melhor atende o comando constitucional de garantia ao direito à vida e a dignidade da pessoa humana. Sustenta seu argumento com o fato de que os

\footnotetext{
${ }^{111}$ GÓES, Jamille Argolo. Direito do nascituro a alimentos. Uma abordagem civil-constitucional. Jus Navigandi, Teresina, ano 15, n.2442, 9 mar. 2010. Disponível em: http://jus.uol.com.br/revista/texto/14464 Acesso em: 11 mar. 2011

${ }^{112}$ GÓES, Jamille Argolo. Direito do nascituro a alimentos. Uma abordagem civil-constitucional. Jus Navigandi, Teresina, ano 15, n.2442, 9 mar. 2010. Disponível em: http://jus.uol.com.br/revista/texto/14464 Acesso em: 11 mar. 2011

${ }^{113}$ GÓES, Jamille Argolo. Direito do nascituro a alimentos. Uma abordagem civil-constitucional. Jus Navigandi, Teresina, ano 15, n.2442, 9 mar. 2010. Disponível em: http://jus.uol.com.br/revista/texto/14464 Acesso em: 11 mar. 2011

${ }^{114}$ GÓES, Jamille Argolo. Direito do nascituro a alimentos. Uma abordagem civil-constitucional. Jus Navigandi, Teresina, ano 15, n.2442, 9 mar. 2010. Disponível em: http://jus.uol.com.br/revista/texto/14464 Acesso em: 11 mar. 2011
} 
natalistas se amparam em lei ordinária, enquanto a teoria concepcionista se ampara em norma constitucional. ${ }^{115}$

Todo o exposto no artigo reflete o que foi o fenômeno da repersonalização do direito civil e como isso influenciou na questão dos alimentos ao nascituro. Afinal, ganha força o argumento de que os alimentos seriam devidos ao nascituro e, a doutrina natalista, perde terreno.

No mesmo sentido que o artigo ora resumido, aparece Marklea da Cunha Ferst. Observe a transcrição:

"Com a repersonalização do direito civil, decorrente da constitucionalização dos direitos civis instituído pela Constituição Federal de 1988, a pessoa é considerada como fundamento das relações civis e não apenas um pólo de uma relação jurídica, mas como um conjunto de atributos inerentes a personalidade humana, que deve ser vista como um valor. Assim, a partir da Constituição de 1988, a pessoa passa a ser o centro do direito e, portanto, merecedora de uma efetiva tutela jurídica dos direitos da personalidade.

(...) É essa valorização dos direitos, decorrentes do principio da dignidade da pessoa humana, que confere ao nascituro o direito a alimentos, pois a Constituição Federal dispõe, no art. 227, que serão atendidos, com absoluta prioridade, o direito à vida, à saúde, entre outros." 116

Há outros dispositivos que protegem a pessoa humana desde a sua concepção tais como o art. $5^{\circ}, 7^{\circ}$ e $8^{\circ}$ do ECA, Convenção sobre os direitos da Criança de 1989 ratificada pelo Brasil (confere proteção jurídica a criança antes e depois do nascimento).

Caio Mario acrescenta quanto a esses argumentos:

"o principio contido no art. $5^{\circ}$ da Constituição de 1988 , segundo o qual o primeiro dos direitos individuais inscreve inviolabilidade do direito à vida, sendo descabido argumentar que tal direito refere-se somente à vida extra-uterina, ou subordinado ao nascimento." 117

Ante todo o exposto nesse histórico acerca do reconhecimento dos alimentos ao nascituro, Maria Berenice Dias resume a importância da Lei de Alimentos Gravídicos, a saber:

"Ainda que inquestionável a responsabilidade parental desde a concepção, o silêncio do legislador sempre gerou dificuldade para a concessão de alimentos ao nascituro. Raras vezes a justiça teve a oportunidade de reconhecer a obrigação alimentar antes do

\footnotetext{
${ }^{115}$ GÓES, Jamille Argolo. Direito do nascituro a alimentos. Uma abordagem civil-constitucional. Jus Navigandi, Teresina, ano 15, n.2442, 9 mar. 2010. Disponível em: http://jus.uol.com.br/revista/texto/14464 Acesso em: 11 mar. 2011

${ }^{116}$ FERST, Marklea da Cunha. Direito na prática: Alimentos e ação de alimentos. Manual do operador do direito. $1^{\mathrm{a}} \mathrm{Ed}$ (ano 2009), $2^{\mathrm{a}}$ reimp. Curitba: Juruá, 2011. p. 57

${ }^{117}$ PEREIRA, Caio Mario da Silva. Instituições de Direito Civil: Direito de Família, vol. 5. 16 ${ }^{\mathrm{a}}$ Ed. rev. e atual. - Rio de Janeiro: Forense, 2007. p. 518
} 
nascimento, pois a lei de alimentos exige prova do parentesco ou da obrigação. $\mathrm{O}$ máximo que se chegou foi, nas ações investigatórias de paternidade, deferir alimentos provisórios quando há indícios do vinculo parental ou após o resultado positivo do teste do DNA. Graças a súmula 301 do STJ, também a resistência em se submeter ao exame passou a servir de fundamento para a antecipação da tutela alimentar." 118

Diante disto, conclui-se que, mesmo diante de tantos argumentos em favor da concessão de alimentos ao nascituro, predominava na jurisprudência a negativa do deferimento dos mesmos devido à lacuna na lei. Tal lacuna fora preenchida pela lei de alimentos gravídicos (Lei 11.804/2008) que alterou esse posicionamento.

\section{Algumas considerações quanto à classificação dos alimentos gravídicos}

a) Quanto à natureza dos alimentos gravídicos

Conforme classificado no capítulo 1 , os alimentos classificam-se quanto à natureza em naturais e civis. Marklea da Cunha Ferst leciona que o direito a alimentos gravídicos deve ser considerado em sentido amplo, isto é, incluindo-se os alimentos civis para proporcionar um desenvolvimento sadio do nascituro. ${ }^{119}$

Assim, estariam inclusas despesas com parto, alimentação da gestante, prénatal, dentre outros compatíveis com a condição social, que, embora não indispensáveis, contribuem com a saúde da gestante e, consequentemente do nascituro - ex. yoga, hidroginástica. ${ }^{120}$ A autora classifica esses exemplos como “despesas com cuidados adicionais".

No mesmo sentido, Ana Maria Gonçalves Louzada já afirmava antes do advento da lei:

"Não só com exames pré-natais o genitor do nascituro deve ficar responsável (ainda que essa responsabilidade não seja total, eis que deve ser repartida com a própria genitora), mas o pai deve contribuir também com relação ao enxoval do bebê." ${ }^{121}$

Portanto, além de garantir o indispensável à manutenção da vida, entendem essas autoras que os alimentos concedidos ao nascituro deveriam também garantir a manutenção de status social compatível com o de seus pais.

\footnotetext{
${ }^{118}$ DIAS, Maria Berenice. Alimentos Gravídicos?. Jus Navigandi, Teresina, ano 13, n.1853, 28 jul. 2008. Disponível em: http://jus.uol.com.br/revista/texto/11540 Acesso: 9 mar. 2011.

${ }^{119}$ FERST, Marklea da Cunha. Op. cit. p. 58

${ }^{120}$ FERST, Marklea da Cunha. Op. cit. p. 60

${ }^{121}$ LOUZADA, Ana Maria Gonçalves. op. cit. p. 41
} 
b) Quanto à causa jurídica dos alimentos gravídicos

É certo que não são alimentos voluntários e nem alimentos indenizatórios. Assim, entendo que os alimentos gravídicos se aproximam dos alimentos legítimos (devidos em virtude de uma obrigação legal que pode decorrer do parentesco), mas não se confundem.

Digo isto, porque o artigo $6^{\circ}$ da Lei de alimentos confere os mesmos com base em meros indícios de parentesco. Ao revés, os alimentos legítimos são deferidos na certeza de parentesco.

Conforme será explanado no capítulo seguinte, a concessão de alimentos gravídicos não faz coisa julgada quanto ao vínculo de parentesco. Assim, não se fala em certeza de parentesco em sede de alimentos gravídicos, mas tão somente em fortes indícios.

4. Pressupostos para concessão de alimentos gravídicos (art.2, parágrafo único e art.6으.11804/2008)

a) Indícios de Paternidade (art. $6^{\circ}$ Lei 11804/2008)

Quanto a esse pressuposto, a lei de alimentos gravídicos diverge dos alimentos decorrentes do vínculo de parentesco. O primeiro é fixado com base em indícios de paternidade; o segundo, com base na certeza de paternidade.

b) Binômio necessidade/possibilidade

Quanto a esse pressuposto, a lei de alimentos gravídicos converge com os alimentos decorrentes do vínculo de parentesco. Nesse sentido, Marklea da Cunha Ferst:

"Vige, tal como nos alimentos decorrentes do vínculo de parentesco, previstos na lei de alimentos e no código civil, o princípio da proporcionalidade, ou seja, os alimentos gravídicos serão fixados respeitando-se o binômio necessidade x possibilidade." 122

\section{Conversão dos Alimentos Gravídicos em Pensão Alimentícia}

Nesse ponto, a meu ver, há certa imprecisão da lei. Observe:

a) A lei somente estabelece que seja feita a conversão. Mas os institutos não se confundem. Os alimentos gravídicos são deferidos tão somente com base em indícios e para a pensão é necessária a prova de parentesco.

${ }^{122}$ FERST, Marklea da Cunha. Op. cit. p. 59 
Assim, como seria possível a conversão tendo em vista que o simples nascimento com vida não é apto a constituir o vínculo parental? A solução, segundo meu entendimento, seria que uma das partes solicitasse sua revisão conforme diz a lei. Notadamente, poderia ser pleiteada ação de investigação de paternidade capaz de constituir ou não o vínculo. Enquanto isso, os alimentos gravídicos seriam mantidos. Decidida a questão, os alimentos passariam a ser definitivos.

b) E se nenhuma das partes propuser a ação de investigação de paternidade? Como se constituiria o vínculo parental capaz de preencher os pressupostos de a obrigação alimentar? A lei não responde a essa pergunta. Nesse ponto, Maria Berenice Dias entende que caso o genitor não proceda ao registro do filho, independentemente de ter buscado o reconhecimento da paternidade, a lei deveria determinar a expedição de mandado de registro. Com isso, seria dispensável a propositura da ação investigatória de paternidade para o estabelecimento do vínculo. ${ }^{123}$

Feitas essas considerações acerca dos aspectos materiais da lei, concluo que, apesar das imprecisões, não se pode negar que a lei foi fundamental para acabar com a discussão acerca da possibilidade de concessão de alimentos ao nascituro.

${ }^{123}$ DIAS, Maria Berenice. Alimentos Gravídicos?. Jus Navigandi, Teresina, ano 13, n.1853, 28 jul. 2008. Disponível em: http://jus.uol.com.br/revista/texto/11540 Acesso em: 9 mar. 2011. 


\section{ASPECTOS PROCESSUAIS DA LEI N¹1.804/2008}

\section{Legitimidade ativa e passiva}

Conforme ressaltado no capítulo 2 deste trabalho, antes da lei apenas uma parcela da jurisprudência admitia o pleito de alimentos pelo nascituro. Todavia, ponderava Carlos Roberto Gonçalves:

"Mesmo a corrente que franqueia ao nascituro o acesso ao judiciário impõe-lhe, porém, como requisito, a demonstração prévia do vínculo de paternidade, como o exige o art. $2^{\circ}$ da Lei de Alimentos (Lei n. 5.478, de 25-7-1968)." 124

Com o advento da lei de alimentos gravídicos, esse problema foi resolvido. Segundo a lei 11.804/2008, não se exige a comprovação do vínculo, mas tão somente a existência de indícios de paternidade.

\subsection{Legitimidade Ativa (art.1 ${ }^{\circ}$ e art.6o, parágrafo único L.11.804/2008)}

Segundo Carlos Roberto Gonçalves ${ }^{125}$, a legitimidade ativa seria da própria gestante. Nesse sentido, Flávio Monteiro de Barros:

"O direito aos alimentos gravídicos é titularizado pela mulher gestante, sendo, pois, ela a parte legítima para a propositura da sobredita ação, conforme se depreende da análise do art. $1^{\circ}$ da Lei n. 11.804/08, independentemente de vínculo conjugal ou união estável com o suposto pai do nascituro.

Enquanto a ação de alimentos movida pelo nascituro é baseada na relação de parentesco, razão pela qual a jurisprudência exige a demonstração do vínculo de paternidade, dificultando, destarte, o êxito desta ação, nos alimentos gravídicos, a legitimidade ativa é da própria gestante, independentemente de existir entre ela e o suposto pai do nascituro casamento ou união estável, bastando apenas a existência de indícios de paternidade, não se exigindo que a relação de filiação seja demonstrada cabalmente." 126

Quanto a essa questão da inexistência de união estável ou casamento entre a gestante e o suposto pai, conclui Rita de Cássia Peres da Rosa:

"Passa a existir uma "nova" legitimada ativa para propor ação de alimentos: a "mulher grávida" - que não seja casada, que não viva em união estável, enfim a autora pode ser a namorada, ou a "ficante", com todas as possíveis variantes, porque a lei visa a fazer o "suposto pai" biológico pagar alimentos." 127

${ }^{124}$ GONÇALVES, Carlos Roberto. Direito Civil Brasileiro: Direito de Família, v. 6. $8^{\text {a }}$ Ed. rev. e atual. São Paulo: Saraiva, 2011. p. 575

${ }^{125}$ GONÇALVES, Carlos Roberto. Direito Civil Brasileiro: Direito de Família, v. 6. $8^{\text {a }}$ Ed. rev. e atual. São Paulo: Saraiva, 2011. p. 575 e 576

${ }_{126}$ BARROS, Flávio Monteiro de. Alimentos Gravídicos. Curso FMB. Disponível em: http://www.cursofmb.com.br/cursofmbjuridico/artigos/download.php?file=ALIMENTOS\%20GRAV\%C DDICOS.pdf Acesso em: 06 mai. 2011.

${ }^{127}$ ROSA, Rita de Cássia Peres da. Alimentos Gravídicos: analise constitucional, obrigacional e processual. Conteúdo Jurídico, Brasília-DF: 18 mar. 2010. Disponível em: http://www.conteudojuridico.com.br/?artigos\&ver=2.26319 Acesso em: 11 mar. 2011 
Assim, pela leitura literal do artigo $1^{\circ}$ da Lei de Alimentos Gravídicos a titularidade desta ação seria da gestante em todas suas variantes, sem necessidade de vínculo matrimonial ou de união estável com o suposto pai, bastando indícios de paternidade.

No entanto, o artigo $6^{\circ}$, parágrafo único da Lei 11.804 traz a possibilidade de conversão dos alimentos gravídicos em pensão alimentícia em favor do menor após o nascimento com vida. Diante disso, conclui Denis Danoso:

"Ainda assim, ao que me parece, inicialmente a titularidade - e, portanto, a legitimidade ativa - seria da própria gestante. Após o nascimento com vida, porém, haveria uma conversão de titularidade, de modo que os alimentos gravídicos passariam à qualidade de pensão alimentícia em favor do menor." 128

$\mathrm{Na}$ jurisprudência, o entendimento parece ser o mesmo, isto é, com o nascimento haveria conversão de titularidade em favor do menor que passaria a ser o legitimado ativo. Nesse sentido, TJ-DF na apelação cível 20090810061229.

No relatório da referida apelação se infere que fora realizado acordo nos autos da ação de alimentos gravídicos. O executado não cumpriu, em dois meses, o acordo. Diante disso, a criança nascida, representada por sua genitora, ajuizou a ação de execução com base no art. 733 do CPC sob pena de prisão. O juiz, ao julgar o caso, indeferiu a petição inicial e extinguiu o processo sem resolução de mérito por considerar inexistente o título executivo e o exeqüente como parte ilegítima. A parte interpôs apelação alegando legitimidade ativa com base no art. $6^{\circ}$, parágrafo único da Lei 11.804/2008.

O voto da relatora, seguido pelos vogais, foi no sentido de conferir legitimidade ativa a criança nascida. Dito isto, merece destaque trecho do voto da Desembargadora VERA ANDRIGHI (relatora) e, posteriormente, a ementa deste julgado $^{129}$ :

"Atente-se, enfim, que a Lei 11.804/08 tem a finalidade de resguardar o pleno desenvolvimento do nascituro, por isso destinam-se os alimentos à genitora. Todavia, em última análise, a prestação foi devida inicialmente em razão do filho e, a sua interrupção por

\footnotetext{
${ }^{128}$ DANOSO, Denis. Alimentos Gravídicos. Aspectos Materiais e processuais da Lei $n^{\circ} 11.804 / 2008$. Jus Navigandi, Teresina, ano 14, n.2028, 19 jan. 2009. Disponível em: http://jus.uol.com.br/revista/texto/12219 Acesso em: 11 mar. 2011.

${ }^{129}$ TJDF. Apelação Cível 20090810061229. $1^{\text {a }}$ Turma Cível. Relatora: Desembargadora Vera Andrighi. Acórdão $\mathrm{n}^{\circ}$ 407.126, Brasília (DF), 13 de jan. 2010. Disponível em: http://www.jusbrasil.com.br/jurisprudencia/8179627/apelacao-ci-vel-apl-61222420098070008-df0006122-2420098070008-tjdf
} 
motivo do nascimento da criança estaria em evidente dissonância do propósito da referida Lei.

Portanto, tendo em vista que o direito aos alimentos não é mais titularizado pela mãe, mas pelo filho a quem é destinada a obrigação, inclusive antes do seu nascimento, eventual execução, decorrente do seu inadimplemento, deverá ser movida pelo titular, ou seja, pelo agora nascido."

"EXECUÇÃO DE ALIMENTOS GRAVÍDICOS. EXTINÇÃO DO PROCESSO. LEGITIMIDADE ATIVA DO NASCIDO. TÍTULO EXECUTIVO. ACORDO JUDICIAL. ART. $6^{\circ}$, PARÁGRAFO ÚNICO, LEI 11.804/08.

I - Nos termos do parágrafo único do art. $6^{\circ}$ da Lei 11.804/08, os alimentos gravídicos, inicialmente requeridos pela genitora, são convertidos em pensão alimentícia em favor do nascido, que passa a ser o titular do direito aos alimentos.

II - O nascido, portanto, tem legitimidade ativa, representado por sua mãe, para ajuizar execução, cujo título executivo é o acordo judicial homologado.

III - Apelação provida."

Em síntese, teríamos inicialmente a legitimidade ativa da gestante para propor ação de alimentos gravídicos. Com o advento do nascimento da criança, haveria conversão de titularidade da ação, e a criança, representada por sua mãe, passaria a ter legitimidade ativa.

Por fim, assevera Denis Danoso que, por esse entendimento, a lei de alimentos gravídicos teria criado uma restrição ao nascituro quanto ao pleito judicial tendo em vista que o nascituro somente teria legitimidade após o nascimento com vida. ${ }^{130}$

Denis Danoso vislumbra a possibilidade de formação de litisconsórcio ativo entre a mãe e o nascituro. Ainda, o pedido feito direta e exclusivamente pelo nascituro. Como fundamento, argumenta que o objetivo da lei é dar suporte a gestação e, portanto, a proteção se dirige ao próprio nascituro. Deste modo, não tem razão de ser a interpretação que nega legitimidade ao nascituro. Assim, conclui o autor:

"Antes de se criar um empecilho processual (ligado à legitimidade ad causam), é preciso imaginar formas de efetividade do direito material." 131

\footnotetext{
${ }^{130}$ DANOSO, Denis. Alimentos Gravídicos. Aspectos Materiais e processuais da Lei $n^{\circ} 11.804 / 2008$. Jus Navigandi, Teresina, ano 14, n.2028, 19 jan. 2009. Disponível em: http://jus.uol.com.br/revista/texto/12219 Acesso em: 11 mar. 2011.

${ }^{131}$ DANOSO, Denis. Alimentos Gravídicos. Aspectos Materiais e processuais da Lei $n^{\circ} 11.804 / 2008$. Jus Navigandi, Teresina, ano 14, n.2028, 19 jan. 2009. Disponível em: http://jus.uol.com.br/revista/texto/12219 Acesso em: 11 mar. 2011.
} 


\subsection{Legitimidade Passiva}

A legitimidade passiva, conforme o artigo $2^{\circ}$, parágrafo único, da lei de alimentos gravídicos, é do futuro pai. Deve ser compreendido, por futuro pai, como sendo aquele que apresente, no mínimo, indícios de paternidade (art. $6^{\circ}$ L.11.804/2008).

Quanto a este ponto, não há controvérsia. Pode ser parte o sujeito que confirma a paternidade e o sujeito que, embora não alegue certeza desta, tem contra si fortes indícios de paternidade.

Thiago Felipe Vargas Simões, no artigo Breves Linhas Sobre Alimentos Gravídicos, trata da questão da possibilidade de litisconsórcio passivo. Para o autor, somente se admitiria tal hipótese no caso de violência sexual praticada por dois ou mais homens. Segue transcrição deste posicionamento:

"Caso a gestante tenha mantido relações sexuais com mais de uma pessoa, entendemos não ser possível a formação de litisconsórcio passivo, vez que tal conduta representará incerteza acerca da condição de suposto pai do nascituro, o que prejudicará a existência de indícios consistentes de paternidade.

Em tais casos, comungamos do entendimento de que poderá haver argüição da exceptio plurium concubentium, que acarretará na improcedência do pedido inicial e, conseqüentemente, na extinção do feito nos termos do artigo 269, I, do CPC.

Apenas em casos de violência sexual praticada contra a mulher por dois ou mais homens é que vislumbramos a possibilidade de formação de litisconsórcio passivo, devendo cada um dos infratores arcar proporcionalmente com os custos da gestação." 132

Flávio Monteiro de Barros posiciona-se no mesmo sentido e, acrescenta outra hipótese de litisconsórcio passivo - quanto houver concubinato conjunto -, a saber:

"Em havendo pluralidade de homens suspeitos da condição de pais da criança, creio que o litisconsórcio passivo só se justifica quando a autora houver sido vítima de algum delito sexual cometido por eles, em concurso de pessoas, ou comprovar o concubinato conjunto entre eles, devendo a sentença estabelecer a divisibilidade da obrigação entre todos. Tratando-se, porém, de prostituta ou mulher depravada, que, no período da concepção, deitou-se com vários homens,o litisconsórcio passivo representa uma confissão da pluralidade de relacionamentos, excluindo a existência de indícios veementes de paternidade sobre um ou outro réu, impondo-se, destarte, a improcedência da ação. Aliás, o

${ }^{132}$ SIMÕES, Thiago Felipe Vargas. Breves linhas sobre os alimentos gravídicos. In: Âmbito Jurídico, Rio Grande, 77, 01/06/2010 [Internet]. Disponível em: http://www.ambitojuridico.com.br/site/index.php?n_link=revista_artigos_leitura\&artigo_id=7562. Acesso em 06 mai. 2011. 
réu acionado judicialmente pode na contestação invocar a "exceptio plurium concubentium", cuja comprovação levará ao insucesso da demanda." ${ }^{133}$

Outro ponto importante quanto à legitimidade passiva é a discussão acerca da possibilidade de extensão da obrigação de pagar alimentos gravídicos aos ascendentes, descendentes ou irmãos (arts. 1696, 1697 CC) ou mesmo complementar a pensão (art.1698 CC).

A partir da leitura da lei 11.804, percebe-se que a lei é omissa quanto a esse ponto. Nesse sentido, afirma Denis Danoso:

"Em uma única passagem (parágrafo único do art.2\%) a Lei de Alimentos Gravídicos se refere expressamente ao pai. De resto, os termos são genéricos (parte ou ré).

Numa leitura mais constitucional, posso afirmar que todas as regras de extensão e complementação se ajustam ao pedido de alimentos gravídicos, respeitadas apenas as exigências processuais.

É claro que o pai é o primeiro - e preferencialmente o único - a integrar a "lista de devedores". Mas, eventualmente, outras pessoas, na forma como demonstrei acima, podem ser chamadas a dar sua contribuição." 134

Thiago Felipe Vargas Simões, no mesmo artigo supracitado, posiciona-se no sentido de admitir alimentos gravídicos avoengos com fundamento no princípio da solidariedade e, em uma aplicação mais contundente do princípio da paternidade responsável.

Adotando entendimento diverso, Flávio Monteiro de Barros entende que a legitimidade passiva é exclusiva do suposto pai. Desta forma, conclui:

“A legitimidade passiva é exclusiva do suposto pai, não se estendendo aos avôs paternos ou outros parentes eventuais do nascituro, cuja obrigação alimentar é sustentada na comprovação do vínculo de parentesco e não apenas em indícios. Nada obsta, porém, que o próprio nascituro, e não sua mãe, mova ação de alimentos contra os avôs paternos e outros parentes, nos moldes do art. 1.698 do Código Civil, mas, nesse caso, impõe-se que o vínculo de parentesco seja comprovado, de preferência por exame de DNA, na própria ação de alimentos, mas estes alimentos não são gravídicos, pois o destinatário não é a gestante e sim o próprio nascituro." 135

Quanto a este tema, Carlos Roberto Gonçalves limita-se a dizer que a legitimidade passiva foi atribuída exclusivamente ao suposto pai, não se

133 BARROS, Flávio Monteiro de. Alimentos Gravídicos. Curso FMB. Disponível em: http://www.cursofmb.com.br/cursofmbjuridico/artigos/download.php?file=ALIMENTOS\%20GRAV\%C DDICOS.pdf Acesso em: 06 mai. 2011

${ }^{134}$ DANOSO, Denis. Alimentos Gravídicos. Aspectos Materiais e processuais da Lei $n^{\circ} 11.804 / 2008$. Jus Navigandi, Teresina, ano 14, n.2028, 19 jan. 2009. Disponível em: http://jus.uol.com.br/revista/texto/12219 Acesso em: 11 mar. 2011.

135 BARROS, Flávio Monteiro de. Alimentos Gravídicos. Curso FMB. Disponível em: http://www.cursofmb.com.br/cursofmbjuridico/artigos/download.php?file=ALIMENTOS\%20GRAV\%C DDICOS.pdf Acesso em: 06 mai.2011 
estendendo a outros parentes do nascituro. ${ }^{136}$ Nesse sentido, jurisprudência do TJ-RJ, no AI220333320108190000, a saber:

"EMENTA. AGRAVO DE INSTRUMENTO. DIREITO DE FAMÍlIA. AÇÃO DE ALIMENTOS GRAVÍDICOS COM PEDIDO DE LIMINAR. DEFERIMENTO AO DIREITO DO NASCITURO. 15\% DOS VENCIMENTOS LÍQUIDOS DO SUPLICADO. INTELIGÊNCIA DO ART.2 $2^{\circ}$ DO CÓDIGO CIVIL INDEFERIMENTO DO PEDIDO DE INCLUSAO DOS GENITORES DO SUPLICADO. Agravo de Instrumento visando à reforma da decisão interlocutória que, indeferiu o pedido de inclusão dos sogros. Decisão correta e não deve ser reformada. Art. 557 do CPC. RECURSO A QUE SE NEGA SEGUIMENTO." 137

\section{Quantum devido (art. 20 L.11.804/2008)}

Conforme leciona Carlos Roberto Gonçalves, os alimentos gravídicos são destinados a cobrir as despesas adicionais do período de gravidez e que sejam dela decorrentes, da concepção ao parto. Ainda, ressalta o renomado doutrinador que o rol trazido pelo artigo $2^{\circ}$ da Lei $11.804 / 2008$ é exemplificativo. ${ }^{138}$ No mesmo sentido, Maria Berenice Dias afirma que o rol não é exaustivo podendo o juiz considerar outras despesas pertinentes. ${ }^{139}$

Relembrando o que fora mencionado no capítulo 2 deste trabalho, alguns autores defendem inclusive que o direito aos alimentos gravídicos deveria ser considerado em sentido amplo, de forma a incluir os alimentos civis neste rol.

Segundo Cícero Goulart de Assis, no artigo Questões Polêmicas dos Alimentos Gravídicos, pela forma como o art.2 ${ }^{\circ}$ foi redigido, os alimentos gravídicos devem cobrir despesas indispensáveis da gravidez ou dela decorrentes e sempre avalizadas por médico ou juiz. Assim, conclui:

"É incontroverso, então, que não estão englobados na definição de alimentos gravídicos, por exemplo, exames de ultra-som destinados somente à vaidade da mãe em ver o filho intrauterino, já que hoje existem exames (ultra-sonografia 3D/4D), capazes de definir com precisão a aparência do feto." ${ }^{140}$

\footnotetext{
${ }^{136}$ GONÇALVES, Carlos Roberto. Direito Civil Brasileiro: Direito de Família, v. 6. $8^{\text {a }}$ Ed. rev. e atual. São Paulo: Saraiva, 2011. p. 576

${ }_{137}$ TJRJ. Agravo de Instrumento $220333320108190000.9^{a}$ Câmara Cível. Relator: Desembargador Marco Aurélio Froes. 14 de set. 2010.2 Disponível em: http://www.jusbrasil.com.br/jurisprudencia/17046293/agravo-de-instrumento-ai-220333320108190000rj-0022033-3320108190000-tjrj

${ }^{138}$ GONÇALVES, Carlos Roberto. Direito Civil Brasileiro: Direito de Família, v. 6. $8^{\text {a }}$ Ed. rev. e atual. São Paulo: Saraiva, 2011. p. 575

${ }^{139}$ DIAS, Maria Berenice. Alimentos Gravídicos?. Jus Navigandi, Teresina, ano 13, n.1853, 28 jul. 2008. Disponível em: http://jus.uol.com.br/revista/texto/11540 Acesso em: 9 mar. 2011

${ }_{140}$ ASSIS, Cícero Goulart de. Questões Polêmicas dos Alimentos Gravídicos. Disponível em: http://www.r2learning.com.br/_site/artigos/artigo_default.asp?ID=1503 Acesso em: 11 mar. 2011
} 
Ainda, para o referido autor, é necessário que a gestante traga na ação os pareceres médicos acerca dos exames e outras determinações que se fizerem necessárias para o desenvolvimento sadio da gestação. Quanto à possibilidade do juiz acrescer despesa que impute relevante e que não foi incluída pelo médico, explica Cícero Goulart de Assis, há duas correntes: uma defende a necessidade de provocação do juízo, sob pena do julgamento ser extra ou ultra-petita e a outra defende que a determinação para acrescer poderia ser feita de ofício. ${ }^{141}$

Importante também para a fixação do quantum é a analise do artigo $2^{\circ}$, parágrafo único da Lei 11.804/2008. Segundo tal dispositivo, as despesas devem ser custeadas pelo futuro pai, considerada a contribuição dada pela gestante, na proporção dos recursos de ambos.

Semelhante aos alimentos lato senso, o juiz irá avaliar as necessidades da parte autora e as possibilidades da parte ré. Conforme leciona Carlos Roberto Gonçalves, o suposto pai não é obrigado a arcar com todas as despesas da gravidez. ${ }^{142}$ As despesas da gravidez serão fixadas proporcionalmente aos rendimentos de ambos. Nesse sentido, AI n 1.0210.09.061222-2/001 (TJMG).

Nesse julgado a agravada pedia alimentos gravídicos e a decisão interlocutória fixou-os a dez salários mínimos. O recorrente alegava que não havia prova idônea que lhe permitisse supor como sendo o pai biológico e pedia a redução dos alimentos fixados. No que tange aos alimentos, a redução foi concedida e o recurso parcialmente provido. Segue transcrição dos fundamentos para a redução do quantum:

"Desta forma, encontram-se presentes os exigíveis indícios de paternidade, sendo cabível a fixação da obrigação alimentar que, contudo, deve obedecer, para sua fixação, ao critério da proporcionalidade.

Neste aspecto, após examinados os documentos juntados, considero que não restou devidamente comprovada a possibilidade do recorrente em arcar com a prestação fixada, como também não foram efetivamente comprovadas as despesas e necessidades da recorrida.

A Lei $n^{\circ} 11.804 / 2008$ enfatiza, em seu art. $2^{\circ}$, parágrafo único que os ALIMENTOS "referem-se à parte das despesas que deverá ser custeada pelo futuro pai, considerando-se a contribuição que também deverá ser dada pela mulher grávida, na proporção dos recursos de ambos".

141 ASSIS, Cícero Goulart de. Questões Polêmicas dos Alimentos Gravídicos. Disponível em: http://www.r2learning.com.br/_site/artigos/artigo_default.asp?ID=1503 Acesso em: 11 mar. 2011

${ }_{142}$ GONÇALVES, Carlos Roberto. Direito Civil Brasileiro: Direito de Família, v. 6. $8^{\text {a }}$ Ed. rev. e atual. São Paulo: Saraiva, 2011. p. 576 
Desta forma, cabe à agravada arcar com parte das despesas referentes à gravidez, não cabendo exclusivamente ao suposto pai esta providência.

Logo, por inexistirem documentos que comprovem as reais necessidades da recorrida entendo que a pensão, nos moldes fixados não está a atender o binômio necessidade-possibilidade, razão pela qual, concedo parcialmente a antecipação da tutela recursal e reduzo a obrigação alimentar para o valor equivalente a 3 salários mínimos." 143

Da mesma forma, a apelação ${ }^{\circ}$ 990.10.168926-0 TJ-SP.

Nesse julgado o apelante-réu alegava que não tinha condições de arcar com os alimentos estipulados pelo juiz a quo e pedia a redução dos mesmos. A alegação fora confirmada e a sentença sofreu reforma nesse ponto. Interessante a transcrição de trecho do voto:

"Desta forma, deve ser levado em consideração o binômio necessidade/possibilidade, portanto, a redução dos alimentos para um salário mínimo por mês se apresenta adequada, destacando-se o princípio da proporção. (...)

Além disso, também cabe a apelada contribuir para a criação e formação da prole, mesmo porque, ultrapassado em muito o estado de gravidez, a genitora está apta a proporcionar também ao alimentado ou alimentada o necessário para a sua sobrevivência digna.

A recorrida sequer apresenta sua qualificação completa, uma vez que o instrumento de procuração omitiu a qualificação profissional, porém, o documento de fls. 38 dispõe que a apelada é auxiliar de enfermagem com ampla experiência profissional, tendo, assim, aptidão de ir em busca de rendimentos compatíveis, até mesmo, para contribuir no sustento da prole." ${ }^{144}$

Ainda nessa questão da fixação dos alimentos na proporção do recurso de ambos, Carlos Roberto Gonçalves cita o AI 70.028.667.988-0- Palmares do Sul, $8^{\text {a }}$ Câm. Cível do TJRS cujo relator foi Claudir Fidélis. No caso, o tribunal reconheceu que haveria indícios de paternidade, seguiu a regra do art.1694 do Código Civil para fixação dos alimentos atendendo o binômio possibilidadenecessidade e fixou os alimentos no montante de $15 \%$ para o pai. Por isso, afirma Carlos Roberto Gonçalves que o tribunal não seguiu a praxe de fixar alimentos provisórios em 30\% porque se ateve ao parágrafo único do art. $2^{\circ}$ da lei 11804

\footnotetext{
${ }^{143}$ TJMG. Agravo de Instrumento $n^{\circ}$ 1.0210.09.061222-2/001 - Comarca de Pedro Leopoldo - Relator: Alberto Vilas Boas. 15 jun. $2010 . \quad$ Disponível em: http://www.tjmg.jus.br/juridico/jt_/inteiro_teor.jsp?tipoTribunal=1\&comrCodigo=210\&ano=9\&txt_proce $\mathrm{sso}=61222 \&$ complemento $=1 \&$ sequencial $=0 \&$ palavrasConsulta $=$ ALIMENTOS\%20GRAVÍDICOS\&toda $\mathrm{s}=\&$ expressao $=\& q u a l q u e r=\& s e \mathrm{~m}=\&$ radical $=$ Acesso em: 16 mai 2011

${ }^{144}$ TJSP. Apelação Cível n ${ }^{\circ} 990.10 .168 .926-0$. Voto ${ }^{\circ}$ 14.028. $4^{\text {a }}$ Câmara de direito Privado do Tribunal de Justiça de São Paulo. Relator: Natan Zelinschi de Arruda. 5 ago. 2010. Disponível em: http://www.jusbrasil.com.br/filedown/dev1/files/JUS2/TJSP/IT/APL_990101689260_SP_128214831390 5.pdf Acesso em: 16 mai 2011
} 
que recomenda que ambos os "pais" participem contribuindo para o pagamento das despesas da gestação. ${ }^{145}$

Ainda, no mesmo sentido decidiu o TJDF na apelação cível 20100111558842. No caso, a gestante pedia que os alimentos fossem deferidos no montante de $30 \%$ dos rendimentos do suposto pai. O suposto pai contestou por meio de provas e alegou não ter meios de arcar com os alimentos no valor pedido pela gestante. O MP se manifestou no sentido de reduzir para $15 \%$ o valor e o juiz acolheu esse patamar. Foi proposta apelação para majorar para $30 \%$ o valor devido pelo suposto pai. A decisão final do recurso foi no sentido da manutenção dos $15 \%$. Segue trecho do voto e a ementa:

"Na hipótese dos autos, tenho que restou plenamente demonstrada a capacidade financeira da apelante, empregada doméstica, e também do apelado, atendente em loja, sendo certo que a renda mensal de ambos é praticamente a mesma, em torno de $\mathrm{R} \$$ 600,00 (seiscentos reais). Ressalto, ainda, que o recorrido comprovou possuir dois outros filhos menores.

Assim, entendo que a r. sentença ao fixar os alimentos em 15\% (quinze por cento) atendeu ao binômio necessidade/ possibilidade, razão pela qual, não merece reformas." 146

\section{"E M E N T A. ALIMENTOS GRAVÍDICOS. FIXAÇÃO. POSSIBILIDADE DE QUEM PRESTA E NECESSIDADE DE QUEM RECEBE.}

Para a concessão do benefício não há necessidade de cognição definitiva a respeito da paternidade, sendo suficiente a existência de indícios da paternidade.

Na fixação dos alimentos gravídicos devidos pelo suposto genitor deve ser considerada a contribuição que deverá ser dada pela gestante, na proporção dos recursos de ambos os genitores.

Observância do binômio possibilidade/necessidade." 147

Por fim, o último ponto a ser analisado no que tange ao "quantum" consiste na possibilidade de fixação de um valor durante a gravidez e outro após o nascimento da criança. Afinal, conforme o artigo $6^{\circ}$, parágrafo único da lei 11.804/2008, após o nascimento com vida, os alimentos gravídicos ficam convertidos em pensão alimentícia.

\footnotetext{
${ }^{145}$ GONÇALVES, Carlos Roberto. Direito Civil Brasileiro: Direito de Família, v. 6. $8^{\text {a }}$ Ed. rev. e atual. São Paulo: Saraiva, 2011. p. 577 e 578

146 TJDF. Apelação Cível 20100111558842APC. $2^{\mathrm{a}}$ Turma Cível. Relatora: Desembargadora CARMELITA BRASIL. 13 abr. 2011. Disponível em: http://www.jusbrasil.com.br/filedown/dev5/files/JUS2/TJDF/IT/APL_507404120108070001_DF_130291 9039963.doc Acesso em 17 de mai 2011

147 TJDF. Apelação Cível 20100111558842APC. $2^{\mathrm{a}}$ Turma Cível. Relatora: Desembargadora CARMELITA BRASIL. 13 abr. 2011. Disponível em: http://www.jusbrasil.com.br/filedown/dev5/files/JUS2/TJDF/IT/APL_507404120108070001_DF_130291 9039963.doc Acesso em 17 de mai 2011
} 
Cícero Goulart de Araujo defende que não há impeditivo para a fixação de um montante específico para o período da gravidez e outro após o nascimento. Como fundamento, alude o autor que a transformação dos alimentos gravídicos em pensão alimentícia é em razão da natureza da obrigação e não em função dos valores. ${ }^{148}$ Maria Berenice Dias concorda que, apesar dos alimentos gravídicos e da pensão alimentícia possuírem parâmetro diverso, nada impede que o juiz fixe um valor para a gestante até o nascimento e fixe alimentos para o filho a partir de seu nascimento. ${ }^{149}$

Em sentido oposto, Carlos Roberto Gonçalves traz o posicionamento de Flávio Yarshell e, na mesma linha, Flávio Monteiro de Barros que termina por não admitir a possibilidade do juiz em estabelecer dois valores, um para antes do parto e outro após o parto. Observe:

Primeiramente, Flávio Yarshell critica a singela conversão dos alimentos trazida pela lei 11804/2008 no artigo $6^{\circ}$, parágrafo único, a saber:

"É um erro proporcionar alimentos durante a gestação, na perspectiva do padrãoeconômico financeiro que se projeta para o momento posterior ao nascimento com vida, assim como é um equivoco supor que os parâmetros de fixação dos alimentos durante a gestação bastem ou que sejam adequados para o momento posterior (...) Alias, em termos estritamente processuais, é de se duvidar que o objeto do processo - o pedido, à luz da causa de pedir - possa ao mesmo tempo abranger alimentos devidos em função da gravidez e os alimentos devidos para o momento subseqüente. (...) não parece possível simplesmente permitir que a partir do nascimento, sejam alterados os fatos constitutivos da pretensão e também o pedido (...) não parece possível formular pedido com base em fatos incertos - não se sabe, ainda, concretamente, quais as necessidades reais de alguém que ainda sequer nasceu com vida - porque isso ou tornaria inepta a inicial ou, novamente, prejudicaria a defesa." 150

Com base nesse raciocínio, Flávio Monteiro de Barros nega a possibilidade de estabelecer dois valores. Argumenta que os alimentos gravídicos são deferidos com base em meros indícios de paternidade. Deste modo, as verbas alimentares devem estar dentro do conteúdo fixado pela lei de alimentos gravídicos, ou seja, devem se limitar a tutela dos direitos do nascituro e da gestante. Para que os alimentos abranjam outras despesas tais como educação, alimentação, saúde e

\footnotetext{
148 ASSIS, Cícero Goulart de. Questões Polêmicas dos Alimentos Gravídicos. Disponível em: http://www.r2learning.com.br/_site/artigos/artigo_default.asp?ID=1503 Acesso em: 11 mar. 2011

${ }^{149}$ DIAS, Maria Berenice. Alimentos Gravídicos? Jus Navigandi, Teresina, ano 13, n.1853, 28 jul. 2008. Disponível em: http://jus.uol.com.br/revista/texto/11540 Acesso em: 9 mar. 2011

${ }^{150}$ GONÇALVES, Carlos Roberto. Direito Civil Brasileiro: Direito de Família, v. 6. $8^{\mathrm{a}}$ Ed. rev. e atual. São Paulo: Saraiva, 2011. p. 576 e 577
} 
etc, é necessária nova ação, seja de alimentos ou investigação de paternidade cumulada com alimentos, na qual haverá ampla possibilidade de prova para atestar ou não a paternidade.

Portanto, ao que parece, para Flávio Monteiro de Barros, o valor deveria ser apenas o apto a custear as despesas oriundas da gravidez. Após o parto, pretendendo a parte ampliar esse valor para adequá-lo as novas necessidades, deveria promover ação de modo a confirmar a paternidade e demonstrar as reais necessidades do novo indivíduo - até porque, conforme explicou Flávio Yarshell, não há como prever as reais necessidades de alguém que sequer nasceu.

\section{3. Ônus da Prova e Indícios de paternidade}

O ônus probatório é da gestante. Nesse sentido, AI 70033946393.

No caso em tela, uma menor ingressou com agravo de instrumento contra a decisão proferida nos autos da ação de alimentos gravídicos que indeferiu o pedido de alimentos gravídicos. A recorrente dizia ter mantido namoro com o suposto pai durante certo período e, após o término, teria continuado se encontrando com o mesmo durante um tempo. Findo o relacionamento, desconfiou da gravidez. Ainda, alegou que não teve relacionamento com nenhum outro homem. Por estar desempregada, ser menor recebendo pensão no valor de irrisórios $\mathrm{R} \$ 100,00$ e o suposto pai estar bem colocado no mercado de trabalho com ganhos em torno de $\mathrm{R} \$ 1000,00$, propôs o AI para a reforma da decisão e deferimento dos alimentos gravídicos.

Segue transcrição de trecho do voto:

"Consoante se depreende da prova trazida com o instrumento, no entanto, não há nesta fase, comprovação ou demonstração pela recorrente, de indícios para o deferimento do pleito, de alimentos provisórios.

O ônus probatório, na fase, é da autora, cabendo a ela apresentar indícios de paternidade, não sendo suficiente à mera atribuição de paternidade pelo simples pedido e a alegação de que não dispõe de recursos para, sozinha, fazer frente às despesas decorrentes de sua condição. Entendimento diverso implicaria em impor ao suposto pai a produção de prova negativa, que é vedada pelo ordenamento jurídico." 151

151 TJRS. Agravo de Instrumento n 70033946393 - Comarca de Caxias do Sul. $7^{\text {a }}$ Câmara Cível Relator: Des, André Luiz Planella Villarinho. 20 dez. 2009. Disponível em: http://www.jusbrasil.com.br/filedown/dev5/files/JUS2/TJRS/IT/AI_70033946393_RS_1289827969901.d oc Acesso em: 16 mai. 2011 
Nesse julgado o tribunal entendeu que a agravante limitou-se a comprovar seu estado de gravidez, uma requisição de ecografia, cartão de gestante e, em relação à prova da relação com o suposto pai, limitou-se a trazer apenas uma foto e um cartão de natal assinado por um homem cujo apelido era "Negão". O tribunal considerou que tais provas colhidas pela agravante não são capazes de revelar indícios mínimos de paternidade e verossimilhança de suas alegações.

Segundo Carlos Roberto Gonçalves, a petição inicial da ação de alimentos gravídicos deve vir instruída com a comprovação da gravidez e dos indícios de paternidade (ex.: cartas, fotos, emails, comprovação da hospedagem em hotel, fotografia que comprove o relacionamento no período da concepção). Por fim, explica o autor que o juiz não pode determinar a realização do exame de DNA por meio da coleta de líquido amniótico porque isso poderia colocar em risco a vida da criança e retardaria o andamento do feito. ${ }^{152}$

Além desses documentos apontados por Carlos Roberto Gonçalves, Marklea acrescenta que a demanda deve vir instruída com comprovante das despesas, de renda do alimentante e da alimentanda. Nesse sentido, AI 2009.00.2.008669-6.

No caso em tela, o pedido de alimentos gravídicos foi indeferido razão pela qual a representante do nascituro interpôs o agravo. Segundo ela, alegava que havia tido relacionamento com o agravado e que durante o namoro não foram vistos em público com frequiência, que o agravado nunca ajudou com as despesas da gestação e que o parto estava orçado em $\mathrm{R} \$ 4.00,00$ e a mesma, por não possuir plano de saúde, necessitava dos alimentos. Os desembargadores conheceram e negaram por unanimidade o provimento por considerar que os documentos juntados aos autos pela agravante não eram aptos a gerar indícios de paternidade. Segue trecho do voto:

"Na espécie analisada, não estão presentes os requisitos necessários ao deferimento do pedido de alimentos provisórios, porque sequer foram trazidos aos autos os orçamentos dos serviços médicos e hospitalares referentes ao parto e o comprovante de rendimentos do agravado, para aferir se tem condições de suportar os alimentos pleiteados.

Além do mais, não foi comprovado, ainda que de forma precária, o alegado relacionamento amoroso entre a representante legal do nascituro e o suposto pai.

\footnotetext{
${ }^{152}$ GONÇALVES, Carlos Roberto. Direito Civil Brasileiro: Direito de Família, v. 6. $8^{\text {a }}$ Ed. rev. e atual. -
} São Paulo: Saraiva, 2011. p. 578 
Para se estabelecer alimentos gravídicos, o d. julgador deve estar convencido da existência de indícios de paternidade." 153

Esse julgado corrobora o acima exposto, isto é, a instrução da demanda deve conter documentos aptos a convencer o magistrado acerca dos indícios de paternidade, orçamento de despesas, comprovante de rendimentos.

Tendo visto alguns dos documentos que devem instruir a demanda, é preciso analisar a questão da prova para a jurisprudência.

A primeira idéia que aparece quando o assunto é prova de paternidade é o exame de DNA. Conforme dito em linhas anteriores, Carlos Roberto Gonçalves explica que o exame realizado em liquido amniótico poderia por em risco a vida do nascituro. No mesmo sentido, Maria Berenice Dias ${ }^{154}$ traz essa explicação. Assim, se a lei visa proteger os direitos do nascituro, seria uma incongruência a exigência de tal exame apto a colocar em risco a vida do mesmo.

Com base nisto, não foi sem razão o veto ao art. $8^{\circ}$ da lei 11804 que condicionava o deferimento de alimentos gravídicos a realização do exame de DNA nos casos em que o suposto pai negasse a paternidade. Segue a transcrição das razões do veto:

"O dispositivo condiciona a sentença de procedência à realização de exame pericial, medida que destoa da sistemática processual atualmente existente, onde a perícia não é colocada como condição para a procedência da demanda, mas sim como elemento prova necessário sempre que ausente outros elementos comprobatórios da situação jurídica objeto da controvérsia." 155

Portanto, o exame de DNA não pode ser colocado como condição para a procedência da demanda, mas apenas como elemento de prova.

Denis Danoso dissertando sobre o tema explica que, pela ordem jurídica, todos os meios de prova são admitidos (art. $332 \mathrm{CPC}$ ). O problema quanto à

153 TJDF. Agravo de Instrumento 20090020086696AGI. $1^{\text {a }}$ Turma Cível. Relatora: Desembargadora MARIA DE FÁTIMA RAFAEL DE AGUIAR RAMOS. 28 out. 2009. Disponível em: http://www.jusbrasil.com.br/filedown/dev2/files/JUS2/TJDF/IT/AI_86696120098070000_DF_12598788 84404.doc Acesso em: 17 mai. 2011

${ }^{154}$ DIAS, Maria Berenice. Alimentos Gravídicos? Jus Navigandi, Teresina, ano 13, n.1853, 28 jul. 2008. Disponível em: http://jus.uol.com.br/revista/texto/11540 Acesso em: 9 mar. 2011

${ }^{155}$ Mensagem no ${ }^{\circ}$ 853. Presidente da República. Casa Civil. Subchefia para assuntos jurídicos. Disponível em: http://www.planalto.gov.br/ccivil_03/_ato2007-2010/2008/Msg/VEP-853-08.htm Acesso em: 16 mai. 2011 
prova da filiação do nascituro se revela na prática. Assim, vetada a exigência do exame pericial, o autor explica como poderia ser constituída a prova, a saber:

"Caberá a mãe, pois, buscar, todos os meios possíveis de demonstrar o alegado. Uma idéia é que não se prove diretamente a paternidade - o que, como visto, não é tarefa das mais fáceis -, mas sim por fatos subjacentes e que possam conduzir a uma presunção de paternidade (art.1597 do Código Civil). Testemunhas e documentos (como cartas e mensagens eletrônicas) revelar-se-ão úteis nesse ponto específico.

Não é por outro motivo, alias, é que a parte inicial do art. $6^{\circ}$ diz que convencido da existência de indícios de paternidade, o juiz fixará alimentos gravídicos. O destaque é proposital, já que revela que na ação de alimentos gravídicos a prova da paternidade não há de ser tão robusta quanto, ao menos teoricamente, o seria na investigação de paternidade.

Faltando, todavia, tais provas, o magistrado não terá outra alternativa a não ser julgar a ação improcedente." 156

Portanto, conforme se infere do exposto, caberá a mãe a prova acerca dos indícios de paternidade. Em relação a isso, Douglas Phillips, no artigo Alimentos Gravídicos e a Lei 11804/2008 ${ }^{157}$ - Primeiros reflexos, acrescenta que o simples pedido da genitora não goza de presunção de veracidade e que o pai, ainda que não possa realizar exame de DNA (utilizado como matéria de defesa) pode produzir determinadas provas como por exemplo a vasectomia.

Com base nessas provas sugeridas pelos autores, corroboro e acrescento casos em que a jurisprudência reconheceu ou negou os indícios para melhor esclarecer o tema. A saber:

O TJSP reconheceu, no AI 994.09.290371-9 ${ }^{158}$, como sendo prova de fortes indícios de paternidade o fato do suposto pai ter confirmado que mantinha relações sexuais com a autora da ação, com quem havia inclusive sido casado e que, mesmo após separados, os encontros continuaram ocorrendo com regularidade. O suposto pai alegou como defesa que, apesar disto, tinha dúvidas da paternidade porque descobriu em site da internet (orkut) indícios de outro relacionamento da autora da ação. Todavia, não produziu provas dessa relação alegada.

\footnotetext{
${ }^{156}$ DANOSO, Denis. Alimentos Gravídicos. Aspectos Materiais e processuais da Lei $n^{\circ} 11.804 / 2008$. Jus Navigandi, Teresina, ano 14, n.2028, 19 jan. 2009. Disponível em: http://jus.uol.com.br/revista/texto/12219 Acesso em: 11 mar. 2011.

157 FREITAS, Douglas Phillips, Alimentos Gravídicos e a Lei 11.804/2008 - Primeiros Reflexos. Disponível em: www.ibdfam.org.br/?artigos\&artigo=468 Acesso em: 16 mai. 2011

158 TJSP. Agravo de Instrumento n ${ }^{\circ}$ 994.09.290371-9. Comarca de Campo Limpo Paulista/ Jundiaí. $4^{a}$ Câm. De Direito Privado. Relator: Ênio Santarelli Zuliani. 13. jan. 2010. Disponível em: http://www.jusbrasil.com.br/filedown/dev1/files/JUS2/TJSP/IT/AI_994092903719_SP_1265401874813. pdf Acesso em: 16 mai. 2011
} 
Já o TJDF negou a existência de indícios de paternidade no AI $20090020119831^{159}$. Nesse processo, a única prova trazida pela agravante eram declarações de vizinhos de que ela havia tido um relacionamento com o agravado. Nas razões de decidir a conclusão firmada é a de que a mera alegação de que as partes mantiveram relacionamento sexual, corroborada por declarações colhidas extrajudicialmente, não é capaz de garantir a concessão dos alimentos gravídicos sem antes sequer ouvir o que tem a dizer o requerido. No mais, no caso em exame, a autora confessou na inicial que o relacionamento era recente e superficial.

Em outro caso, porém, o TJDF reconheceu a existência de indícios de paternidade. Conforme se infere do AI $20090020149469^{160}$, a genitora apresentou como prova um testemunho de que as partes conviveram em união estável, demonstrou que estava desempregada e, portanto, necessitava do auxílio do suposto pai do nascituro. O agravante-réu limitou-se a dizer que a prova produzida era frágil já que se baseava em testemunho da amiga da genitora. Todavia, durante a instrução do processo admitiu a existência de relacionamento amoroso.

O TJSC, no AI ${ }^{\circ}$ 2010.029905-5 ${ }^{161}$, reconheceu como fortes indícios de paternidade o contrato de locação que demonstra que os litigantes alugaram em conjunto um imóvel residencial durante um ano, o que induz que eles viveram em união estável; o fato do agravante não negar o relacionamento com a agravada e nem o fato de terem mantido relações sexuais e a data do nascimento da criança que permite afirmar que a concepção aconteceu no período em que os litigantes conviviam maritalmente. $\mathrm{O}$ agravante alegava dúvidas acerca de sua

\footnotetext{
159 TJDF. Agravo de Instrumento 20090020119831. 5a Turma Cível. Relator: Desembargador Lecir Manoel da Luz. 11 nov. 2009 Disponível em: http://www.jusbrasil.com.br/filedown/dev2/files/JUS2/TJDF/IT/AI_119831520098070000_DF_1259873 093591.doc Acesso em: 17 mai. 2011

${ }^{160}$ TJDF. Agravo de Instrumento ${ }^{\circ}$ 20090020149469. $1^{\text {a }}$ Turma Cível. Relatora: Desembargadora Vera Andrighi. 16 dez. 2009.2 Disponível em: http://www.jusbrasil.com.br/filedown/dev2/files/JUS2/TJDF/IT/AI_149469320098070000_DF_1267043 302045.doc Acesso em: 16 mai 2011

${ }^{161}$ TJSC. AI n ${ }^{\circ} 2010.029905-5$, de Blumenau. $2^{\text {a }}$ Câmara de Direito Cível. Relator: Jaime Luiz Vicari. 14 set. 2010.2 Disponível em: http://www.jusbrasil.com.br/filedown/dev5/files/JUS2/TJSC/IT/AI_299055_SC_1300111661783.doc Acesso em: 16 mai. 2011
} 
paternidade e que seria necessário aguardar o nascimento da criança para que fosse realizada prova técnica capaz de estabelecer a obrigação alimentícia. Corroborando todo o exposto em linhas acima, o tribunal proferiu voto no sentido de que a fixação de alimentos gravídicos não exige prova concreta de paternidade, como pretendia o suposto pai. No mais, no caso em exame, havia fortes indícios capazes de conferir o deferimento dos alimentos ao nascituro. Por isso, julgou correta a decisão do magistrado a quo que fixou os alimentos gravídicos.

O TJMG, no AI 1.0210.09.061222-2/001 (1) ${ }^{162}$, reconheceu indícios de paternidade, mesmo o agravante negando ter mantido relações sexuais com a agravada, tomando como base fotografias colacionadas aos autos, transcrição das mensagens enviadas, via email ou MSN que comprovavam, em sede de cognição sumária, a existência de relacionamento entre as partes.

Ao revés, o TJPR, no AI 606413-3 ${ }^{163}$, considerou que as fotografias juntadas não configuram por si só elemento bastante de prova a ponto de caracterizar indício probatório mínimo.

Por fim, o TJPR proferiu decisão no $\mathrm{AI} \mathrm{n}^{\circ}$ 595.601-4 ${ }^{164}$, no sentido de reconhecer indícios de paternidade com base no fato de que o suposto pai é pai de outra filha do casal, existência de fotos que demonstravam que até pouco tempo atrás o casal vivia em união estável e que a concepção, por simples conferência de datas, ocorreu no período em que os litigantes conviviam maritalmente. O suposto pai alegava em sua defesa que já se encontrava separado de fato da agravada antes da data em que consta no termo de dissolução da

\footnotetext{
162 TJMG. AI ${ }^{\circ}$ 102100906122220011. $2^{\text {a }}$ Vara Cível da Comarca de Pedro Leopoldo. Relator: Desembargados Alberto Vilas Boas. 02 out. 2009. Disponível em: http://www.jusbrasil.com.br/jurisprudencia/6025315/102100906122220011-mg-1021009061222-2-0011-tjmg Acesso em: 16 mai. 2011

${ }^{163}$ TJPR. AI n ${ }^{\circ}$ 606413-3. $2^{\text {a }}$ Vara de Família do Foro Central da Comarca da Região Metropolitana de Curitiba. Relator: Antonio Domingos Ramina Junior. 25 nov. 2009 Disponível em: http://www.jusbrasil.com.br/jurisprudencia/6083020/agravo-de-instrumento-ai-6064133-pr-0606413-3tjpr/inteiro-teor Acesso em: 16 mai. 2011

${ }^{164}$ TJPR. AI n 595.601-4, da Comarca de Cianorte. Vara da Infância e da Juventude e Anexos. Relator: Luiz Antonio Barry. 18 nov. 2009. Disponível em: http://www.jusbrasil.com.br/jurisprudencia/6127433/agravo-de-instrumento-ai-5956014-pr-0595601-4tjpr/inteiro-teor Acesso em: 16 mai. 2011
} 
sociedade de fato. O AI concedeu os alimentos concordando que havia fortes indícios de paternidade.

Portanto, a análise do que serve para configurar indícios de paternidade será feita no caso concreto. Exemplificando: Conforme ficou demonstrado, em determinado julgado a simples presença de fotos não foi suficiente a constituir a provável paternidade e em outro, somada a outros elementos serviu de fundamento.

\section{Possibilidade de tutela antecipada}

De acordo com Denis Danoso ${ }^{165}$, é perfeitamente possível a tutela antecipada em sede de alimentos gravídicos. Tal tutela segue o rito do art. 273 do CPC e estaria condicionada ao preenchimento dos pressupostos legais da medida. Assim, o pressuposto comum a tutela antecipada seria a prova inequívoca da verossimilhança da alegação. Além disso, a hipótese deve representar uma situação de urgência (art.273, caput c/c art. 273, I CPC), abuso do direito de defesa ou manifesto propósito protelatório do réu (art.273, caput c/c art.273, II CPC) ou ser caso de incontrovérsia do pedido (art.273 caput c/c art. $273 \$ 6^{\circ} \mathrm{CPC}$ ).

Ao que parece, a jurisprudência tem sido conservadora no sentido de deferir a antecipação de tutela em sede de alimentos gravídicos.

Conforme se infere, o TJSP, no AI n 990.10.204511-0 166, negou a antecipação de tutela. No caso, fora interposto agravo de instrumento contra a decisão que havia concedido a antecipação de tutela dos alimentos gravídicos. $\mathrm{O}$ agravante alegava que não foram demonstrados indícios convincentes de sua paternidade, a única prova produzida foram declarações colhidas extrajudicialmente e que não tiveram a chance de serem indagadas em audiência ferindo o contraditório e a ampla defesa. No fundamento da decisão do AI foi dito que a concessão de tutela, nesses casos, deve atender três requisitos existência de prova inequívoca, verossimilhança da alegação e fundado receio de

\footnotetext{
${ }^{165}$ DANOSO, Denis. Alimentos Gravídicos. Aspectos Materiais e processuais da Lei ${ }^{\circ} 11.804 / 2008$. Jus Navigandi, Teresina, ano 14, n.2028, 19 jan. 2009. Disponível em: http://jus.uol.com.br/revista/texto/12219 Acesso em: 11 mar. 2011.

${ }^{166}$ TJSP. AI n ${ }^{\circ} 990.10 .204511-0$, da Comarca de Jundiaí. $6^{\text {a }}$ Câmara de Direito Privado. Relator: Vito Guglielmi. 5 ago. 2010. Disponível em: http://www.jusbrasil.com.br/jurisprudencia/15824111/agravo-deinstrumento-ai-990102045110-sp-tjsp Acesso em: 16 mai. 2011
} 
dano irreparável ou de difícil reparação. Tais requisitos seriam aditivos e a ausência de um deles impediria a antecipação de tutela. Assim, considerou que, não sendo as partes casadas, não haveria prova preconstituída. Ainda, considerou ausente o dano irreparável ou de difícil reparação já que, caso seja julgada procedente a ação, os alimentos retroagirão a partir da citação. Dessa forma, negou a antecipação. No mais, relembrou que os alimentos são irrepetíveis e, portanto, a concessão da medida antecipatória deve ser vista com atenção redobrada pelo juiz. A seguir, transcrição da ementa deste caso:

“Alimentos. Gravídicos. Antecipação de Tutela. Inadmissibilidade. Ausência de prova preconstituída da paternidade. Hipótese em que as partes não são casadas. Caso, ademais, em que não há dano irreparável ou de difícil reparação, uma vez que, se devidos, os alimentos retroagem à data da citação. Decisão Reformada. Recurso Provido."

Em outro caso, AI $n^{\circ}$ 990.10.440913-6 ${ }^{167}$, o TJSP também negou a antecipação de tutela em sede de alimentos gravídicos. Nesse processo, a decisão interlocutória negou a antecipação de tutela por entender que inexistiam indícios mínimos da paternidade. $O$ requerente, insistindo na necessidade da medida propôs o agravo de instrumento sob o fundamento que se encontrava no sétimo mês de gestação e não poderia prover o próprio sustento por estar desempregada e seus rendimentos se limitarem aos do seguro desemprego. Em contrapartida, alegava que o agravado possuía vínculo de emprego e recebia remuneração suficiente para prestar os alimentos. O tribunal, no julgamento do agravo, entendeu que não havia indícios mínimos de paternidade com base nas provas trazidas pela gestante e, ainda, não havia como se auferir as possibilidades do requerido de prestar alimentos ou as necessidades da parte autora que não trouxe documentos aptos a comprovar tal pretensão. Com isso, o tribunal decidiu por aguardar a resposta do agravado até que surjam melhores elementos para solucionar o caso.

Assim, é possível perceber que, ainda que seja possível a tutela antecipada em sede de alimentos gravídicos, sua concessão é de fato bastante difícil na prática, seja pela dificuldade de se produzir prova inequívoca, seja pelo fato de não

${ }^{167}$ TJSP. AI n ${ }^{\circ}$ 990.10.440913-6, da Comarca de São Paulo. 10ª Câmara de Direito Privado. Relator: Testa Marchi. 23 nov. 2010. Disponível em: http://www.jusbrasil.com.br/filedown/dev1/files/JUS2/TJSP/IT/_4409131320108260000_SP_129407887 7620.pdf Acesso em: 16 mai. 2011 
representar perigo de dano irreparável conforme afirmava o primeiro julgado apresentado.

\section{Limites da coisa julgada}

Conforme assevera Denis Danoso ${ }^{168}$, mesmo quando a ação de alimentos gravídicos é julgada procedente, não se cria uma relação jurídica formal de paternidade. Nesse sentido, assevera o autor que a coisa julgada somente se forma em relação aos alimentos gravídicos, jamais quanto a paternidade. Para se aferir a paternidade será necessária a ação de investigação de paternidade ou a ação negatória de paternidade.

Nessa mesma linha, Carlos Roberto Gonçalves ${ }^{169}$ afirma que, após o nascimento com vida, o vínculo provisório da paternidade pode ser desconstituído mediante ação de exoneração da obrigação alimentícia com a realização do exame de DNA.

Ainda, conforme se infere da leitura a contra-senso do artigo de Maria Berenice Dias ${ }^{170}$, se, após o nascimento com vida é necessário ação investigatória de paternidade ou procedimento de averiguação para o estabelecimento do vínculo parental, é porque este vínculo não se constitui pelo mero deferimento dos alimentos gravídicos.

Portanto, é de comum entendimento entre os autores que a sentença que concede os alimentos gravídicos encontra limites em sua coisa julgada, isto é, não é apta a constituir o vínculo de parentesco.

\section{Citação e termo inicial}

Segundo Maria Berenice Dias, a lei de alimentos gravídicos estabelecia como termo inicial dos alimentos a data da citação $\left(\operatorname{art.} 9^{\circ}\right.$ ), o que se afigura contraditório já que estes alimentos destinam-se a custear as despesas da concepção até o parto. Desde já, a autora apresentava criticas no sentido de que

\footnotetext{
${ }^{168}$ DANOSO, Denis. Alimentos Gravídicos. Aspectos Materiais e processuais da Lei $n^{\circ} 11.804 / 2008$. Jus Navigandi, Teresina, ano 14, n.2028, 19 jan. 2009. Disponível em: http://jus.uol.com.br/revista/texto/12219 Acesso em: 11 mar. 2011.

${ }^{169}$ GONÇALVES, Carlos Roberto. Direito Civil Brasileiro: Direito de Família, v. 6. $8^{\text {a }}$ Ed. rev. e atual. São Paulo: Saraiva, 2011. p. 578

${ }_{170}$ DIAS, Maria Berenice. Alimentos Gravídicos?. Jus Navigandi, Teresina, ano 13, n.1853, 28 jul. 2008. Disponível em: http://jus.uol.com.br/revista/texto/11540 Acesso em: 9 mar. 2011
} 
isso iria gerar manobras do réu para se esquivar do oficial de justiça. No mais, isso se chocaria com a jurisprudência consolidada dos tribunais e com a lei de alimentos que determinava que o juiz fixasse, ao despachar a inicial, alimentos provisórios. $^{171}$

Adotando as criticas da doutrina, o art. $9^{\circ}$ foi vetado. Segue a transcrição das razoes do veto:

"O art. 9 prevê que os alimentos serão devidos desde a data da citação do réu. Ocorre que a prática judiciária revela que o ato citatório nem sempre pode ser realizado com a velocidade que se espera e nem mesmo com a urgência que o pedido de alimentos requer. Determinar que os alimentos gravídicos sejam devidos a partir da citação do réu é condená-lo, desde já, à não-existência, uma vez que a demora pode ser causada pelo próprio réu, por meio de manobras que visam impedir o ato citatório. Dessa forma, o auxílio financeiro devido à gestante teria início no final da gravidez, ou até mesmo após o nascimento da criança, o que tornaria o dispositivo carente de efetividade." ${ }^{172}$

Dissertando sobre esse tema, Cícero Goulart de Assis ${ }^{173}$ diz que, apesar do veto, a regra continua a mesma, porque o CPC (art.214), aplicado supletivamente, e a jurisprudência já consolidada na súmula 277 STJ, determinam os alimentos a partir da citação. Todavia, o autor admite que, por uma interpretação sistemática e hermenêutica, atentando para a finalidade da lei e os motivos do veto, os alimentos poderiam ser pleiteados desde a concepção.

Ainda, Douglas Phillips Freitas e o IBDFAM defendem que os alimentos sejam devidos a partir do momento em que o juiz distribui a ação. Observe a transcrição:

"O projeto previa que os alimentos sejam pagos desde a data da citação do réu (Art. 9). A paternidade não é configurada a partir do momento em que o oficial de justiça cita o réu de uma ação dessa natureza. "Pai é assim o é desde a concepção do filho", é a máxima sustentada pelo IBDFAM, que defende que os alimentos sejam devidos pelo pai desde o momento em que o juiz distribui a ação, evitando que o réu atrase a tramitação da ação ao esquivar-se de receber o oficial de justiça." 174

\footnotetext{
${ }^{171}$ DIAS, Maria Berenice. Alimentos Gravídicos?. Jus Navigandi, Teresina, ano 13, n.1853, 28 jul. 2008. Disponível em: http://jus.uol.com.br/revista/texto/11540 Acesso em: 9 mar. 2011

${ }^{172}$ Mensagem $n^{\circ}$ 853. Presidente da República. Casa Civil. Subchefia para assuntos jurídicos. Disponível em: http://www.planalto.gov.br/ccivil_03/_ato2007-2010/2008/Msg/VEP-853-08.htm Acesso em: 16 mai. 2011

173 ASSIS, Cícero Goulart de. Questões Polêmicas dos Alimentos Gravídicos. Disponível em: http://www.r2learning.com.br/_site/artigos/artigo_default.asp?ID=1503 Acesso em: 11.03.2011

174 FREITAS, Douglas Phillips, Alimentos Gravídicos e a Lei 11.804/2008 - Primeiros Reflexos. Disponível em: www.ibdfam.org.br/?artigos\&artigo=468 Acesso em: 16 mai. 2011
} 
Thiago Felipe Vargas Simões ${ }^{175}$ sustenta que, fixados os alimentos no início da lide, estes passam a serem devidos não a partir da citação, mas, sim, com efeitos retroativos a data da concepção.

\section{Competência e o veto do art. $3^{\circ}$ da Lei $11804 / 2008$}

$\mathrm{O}$ artigo $3^{\circ}$ da lei previa que o foro competente para propor a ação seria $\mathrm{o}$ domicílio do réu. Felizmente, o artigo foi vetado sob as seguintes razões:

"O dispositivo está dissociado da sistemática prevista no Código de Processo Civil, que estabelece como foro competente para a propositura da ação de alimentos o do domicílio do alimentando. $\mathrm{O}$ artigo em questão desconsiderou a especial condição da gestante e atribuiu a ela o ônus de ajuizar a ação de alimentos gravídicos na sede do domicílio do réu, que nenhuma condição especial vivência, o que contraria diversos diplomas normativos que dispõem sobre a fixação da competência." 176

Assim, o foro competente para propor a ação de alimentos permanece como sendo o domicílio do alimentando.

\section{Rito a ser seguido}

Segundo Marklea da Cunha Ferst ${ }^{177}$, como o art.11 da lei prevê a aplicação subsidiária da lei de alimentos e do CPC, recebida a inicial e convencido da existência de indícios de paternidade, o juiz fixa os alimentos gravídicos designando desde logo audiência de conciliação e julgamento. Caso seja julgado procedente o pedido, os alimentos permaneceram até o nascimento da criança quando, então, serão convertidos em pensão alimentícia até que uma das partes peça a exoneração ou revisão.

Ainda, Cícero Goulart de Assis ${ }^{178}$ diz que, pela regra supletiva da lei dos alimentos, a execução dos alimentos gravídicos segue a sistemática do art. 732 e 733 do CPC, admitindo, portanto, a prisão por dívida alimentar.

\footnotetext{
175 SIMÕES, Thiago Felipe Vargas. Breves linhas sobre os alimentos gravídicos. In: Âmbito Jurídico, Rio Grande, 77, 01/06/2010 [Internet]. Disponível em: http://www.ambitojuridico.com.br/site/index.php?n_link=revista_artigos_leitura\&artigo_id=7562. Acesso em 06/05/2011.

${ }^{176}$ Mensagem n ${ }^{\circ}$ 853. Presidente da República. Casa Civil. Subchefia para assuntos jurídicos. Disponível em: http://www.planalto.gov.br/ccivil_03/_ato2007-2010/2008/Msg/VEP-853-08.htm Acesso em: 16 mai. 2011

${ }^{177}$ FERST, Marklea da Cunha. Alimentos \& Ação de Alimentos - Manual do Operador do Direito. $1^{\mathrm{a}}$ Ed. (ano 2009), $2^{\mathrm{a}}$ reimp./ Curitiba: Juruá, 2011.

178 ASSIS, Cícero Goulart de. Questões Polêmicas dos Alimentos Gravídicos. Disponível em: http://www.r2learning.com.br/_site/artigos/artigo_default.asp?ID=1503 Acesso em: 11.03.2011
} 


\section{Ação revisional e exoneração}

Conforme explica Cícero Goulart de Assis ${ }^{179}$, os alimentos são automaticamente extintos em caso de aborto espontâneo ou comprovação, após o nascimento, por prova cabal - tal como o exame de DNA, da negativa de paternidade. $\mathrm{O}$ autor ressalva as despesas que necessárias para propiciar a recuperação da saúde da gestante.

Em relação a revisão dos alimentos gravídicos, conforme se infere do art. $6^{\circ}$, parágrafo único da lei, os alimentos serão convertidos após o nascimento e serão devidos até que uma das partes solicite sua revisão.

Quanto a isso, Cícero Goulart de Assis ${ }^{180}$ entende que, ainda que ainda não tenha ocorrido o nascimento, alterando-se a situação fática, é possível propor ação revisional.

\section{Possibilidade de aplicação da Lei $11.804 / 2008$ em ação ajuizada anteriormente a referida lei}

Conforme se infere da jurisprudência do TJMG, na apelação cível 1.0702.08.501783-9/001, é perfeitamente possível aplicar a lei 11.804/2008 a ações que se iniciaram antes de seu advento, desde que a autora ainda esteja grávida. Assim, não cabe falar em impossibilidade jurídica do pedido, mas sim aplicar os princípios da instrumentalidade das formas e aproveitamento dos atos processuais.

No caso em tela, a autora pedia recebimento de alimentos tendo em vista que a gravidez aumentou muito seus gastos. O juiz extinguiu a ação nos termos do art. 267 inc. I c/c art. 295, inc. I do CPC alegando a impossibilidade jurídica do pedido por faltar a comprovação do parentesco exigida pela lei 5.468/68 no art. $2^{\circ}$ e pelo art. 1694 do CC. Diante disso, a autora apelou e salientou a existência do projeto de lei que tratava dos alimentos gravídicos. A procuradoria de justiça entendeu que com a edição da lei 11.804/2008, a sentença deveria ser

\footnotetext{
179 ASSIS, Cícero Goulart de. Questões Polêmicas dos Alimentos Gravídicos. Disponível em: http://www.r2learning.com.br/_site/artigos/artigo_default.asp?ID=1503 Acesso em: 11.03.2011

${ }_{180}$ ASSIS, Cícero Goulart de. Questões Polêmicas dos Alimentos Gravídicos. Disponível em: http://www.r2learning.com.br/_site/artigos/artigo_default.asp?ID=1503 Acesso em: 11.03.2011
} 
cassada e o feito deveria seguir regularmente. Para fundamentar a decisão, segue trecho do voto:

"Não se olvida para o fato de que quando do ajuizamento da presente ação em 11/09/2008, (certidão de f. 20), a referida Lei ainda não estava em vigor, inexistindo qualquer norma que disciplinasse a concessão de alimentos para a gestante.

Sobre a questão da intertemporalidade de normas, reza o art. $\underline{6^{\circ}}$ da Lei de Introdução ao Código Civil; "A Lei em vigor terá efeito imediato e geral, respeitados o ato jurídico perfeito, o direito adquirido e a coisa julgada."

A referida disposição legal traduz-se na regra geral da irretroatividade, pela qual não se aplica a lei nova, a situações constituídas sob a vigência da lei modificada, que deve ser utilizada sob o fundamento da certeza e segurança jurídica. Todavia, não há impedimento absoluto à retroatividade da lei, considerada exceção à regra da irretroatividade, desde que a mesma não ofenda o ato jurídico perfeito, o direito adquirido e coisa julgada.

No caso em tela, o fato que fundamenta o pedido, qual seja, a gravidez da Autora, configura situação atual, porquanto é de se presumir que a Requerente ainda esteja grávida, ou já tenha dado a luz ao filho. Assim, a lei nova não está retroagindo, mas dirimindo uma situação atual, nada obstando a aplicação da referida Lei

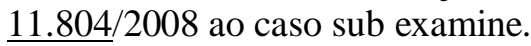

Ademais, a moderna concepção de processo, sustentada pelos princípios da economia, instrumentalidade e celeridade processual, determina o aproveitamento máximo dos atos processuais, principalmente quando não há prejuízo para a defesa das partes." 181

Portanto, é perfeitamente cabível a aplicação da lei 11.804/2008 quando o ato jurídico perfeito ainda não tiver ocorrido.

\section{Responsabilização da parte autora e veto do art.10}

Conforme explica Carlos Roberto Gonçalves ${ }^{182}$, o artigo 10 do projeto de lei previa que, na hipótese de negativa de paternidade após o nascimento da criança, o autor deveria responder por danos materiais e morais causados ao réu.

Maria Berenice Dias já criticava esse artigo. Observe a transcrição:

"Apesar de aparentemente consagrar o princípio da proteção integral, visando assegurar o direito a vida do nascituro e de sua genitora, nítida a postura protetiva em favor do réu. Gera algo nunca visto: a responsabilização da autora por danos materiais e morais a ser apurada nos mesmos autos, caso o exame da paternidade seja negativo. Assim, ainda que não tenha sido imposta a obrigação alimentar, o réu pode ser indenizado, pelo só fato de ter sido acionado em juízo. (...) Trata-se de flagrante afronta ao princípio constitucional do acesso a justiça." 183

\footnotetext{
181 TJMG. Apelação Cível $\mathrm{n}^{\circ}$ 1.0702.08.501783-9/001, Comarca de Uberlândia. 4a Câmara Cível. Relator: Dárcio Lopardi Mendes. 26 mar. 2009. Disponível em: http://www.jusbrasil.com.br/jurisprudencia/5990151/107020850178390011-mg-1070208501783-9-0011-tjmg/inteiro-teor Acesso em: 16 mai. 2011

${ }^{182}$ GONÇALVES, Carlos Roberto. Direito Civil Brasileiro: Direito de Família, v. 6. $8^{\text {a }}$ Ed. rev. e atual. São Paulo: Saraiva, 2011. p. 578

${ }_{183}$ DIAS, Maria Berenice. Alimentos Gravídicos?. Jus Navigandi, Teresina, ano 13, n.1853, 28 jul. 2008. Disponível em: http://jus.uol.com.br/revista/texto/11540 Acesso em: 9 mar. 2011
} 
Nessa linha de raciocínio estão as razoes do veto, a saber:

"Trata-se de norma intimidadora, pois cria hipótese de responsabilidade objetiva pelo simples fato de se ingressar em juízo e não obter êxito. $\mathrm{O}$ dispositivo pressupõe que o simples exercício do direito de ação pode causar dano a terceiros, impondo ao autor o dever de indenizar, independentemente da existência de culpa, medida que atenta contra o livre exercício do direito de ação." 184

A pergunta que se segue é: caso ao final do processo, com o nascimento da criança e a realização do exame de DNA o suposto pai venha a ter confirmado que não era o pai, poderia promover a responsabilização da parte autora?

Carlos Roberto Gonçalves ${ }^{185}$, explica que, ainda que haja o veto do art.10, há a possibilidade de promover ação de responsabilização com base no art. 186 do CC. Todavia, diferente do que previa o artigo 10 - responsabilidade objetiva para que logre êxito na ação o autor deverá demonstrar prova de dolo ou culpa em sentido estrito do causador do dano - responsabilidade subjetiva.

Mesmo com essa possibilidade, Carlos Roberto Gonçalves pondera ao dizer que não se pode ser rigoroso para a aferição da culpa ou dolo da gestante, sob pena de criar excessiva restrição ao direito de postular em juízo. Para o autor, a única culpa capaz de justificar a responsabilização da mulher é aquela que revele total ausência de cautelas mínimas por parte da mesma. Em outras palavras, o doutrinador sustenta que somente a culpa grave ou o dolo seriam aptos a servir de fundamento para a responsabilização com base no art. 186 do CC.

Por fim, cabe lembrar que, se julgada improcedente a ação de alimentos por conta da negativa de paternidade, descabe a repetição de indébito tendo em vista que as verbas alimentares são irrepetíveis.

\footnotetext{
${ }^{184}$ Mensagem n ${ }^{\circ}$ 853. Presidente da República. Casa Civil. Subchefia para assuntos jurídicos. Disponível em: http://www.planalto.gov.br/ccivil_03/_ato2007-2010/2008/Msg/VEP-853-08.htm Acesso em: 16 mai. 2011

${ }^{185}$ GONÇALVES, Carlos Roberto. Direito Civil Brasileiro: Direito de Família, v. 6. $8^{\text {a }}$ Ed. rev. e atual. - São Paulo: Saraiva, 2011. p. 578 e 579.
} 


\section{CONCLUSÃO}

Conforme mencionado na introdução, este trabalho se propôs a tratar dos principais aspectos da lei de alimentos gravídicos. Assim, através da análise conjunta dos três capítulos, apresento algumas conclusões sobre temas que merecem destaque na lei.

No capítulo II deste trabalho, ao tratar das teorias da personalidade e do direito à vida, fora mencionado que $\mathrm{o}$ art. $2^{\circ}$ do código civil estabelece o início da personalidade civil com o nascimento com vida, mas resguarda os direitos do nascituro. Para os que defendiam o direito ao pleito alimentar pelos nascituros, o fundamento seria que é do direito à vida que decorrem todos os demais direitos. Assim, resguardar os direitos do nascituro inclui, de certo modo, resguardar a vida do nascituro promovendo uma gestação sadia. O objetivo da lei 11.804/2008 parece ter sido justamente garantir uma gestação sadia para propiciar o nascimento com vida daquele feto.

$\mathrm{O}$ art. $2^{\circ}$ da lei $11.804 / 2008$, conforme a doutrina afirma, não traz um rol exaustivo das despesas e com isso abre margem para a discussão acerca da amplitude dessas despesas adicionais.

Por isso, no capítulo II, fora dito que certos doutrinadores entendem que o nascituro poderia pleitear alimentos em sentido amplo, isto é, que estivessem de acordo com as condições sociais dos pais. Tal interpretação deve ser analisada no caso concreto cuidadosamente para evitar que se fuja demasiadamente do objetivo da lei. Explique-se:

Se o objetivo da lei foi garantir uma gestação saudável, é certo que quaisquer alimentos necessários nesse sentido devem ser concedidos.

Ana Maria Louzada trouxe como exemplo a contribuição que o suposto pai deveria dar para o enxoval do bebê. Analisando a questão do ponto de vista dos alimentos em geral, seria perfeitamente possível tal pleito. Afinal, o conceito de alimentos trazido no capítulo I teria uma acepção muito mais ampla do que somente a garantia à vida, os alimentos abrangeriam outras necessidades relativas ao desenvolvimento completo do indivíduo. Dentre essas necessidades está o 
vestuário. Analisando a questão pelo ponto de vista que se trata de um alimento destinado ao nascituro, ainda assim defendo que poderia estar abrangido dentro dos objetivos da lei tal pleito. De fato, o enxoval do bebê está relacionado não ao nascituro, mas a criança após o nascimento. Todavia, a lei determina no $\operatorname{art}^{\circ} 6^{\circ}$, parágrafo único que após o nascimento os alimentos serão convertidos em pensão alimentar até que uma das partes solicite sua revisão. Assim, sopesando as necessidades do nascituro ao nascer (vestuário não se trata de mera futilidade), a própria conversão determinada pela lei (os alimentos propriamente ditos incluem despesas com vestuários) e a possibilidade do suposto pai custear as despesas adicionais com vestuário (respeitada à proporção do recurso de ambos os pais), concluo que a lei engloba em seu rol as despesas com enxoval.

Marklea da Cunha Ferst, também expandindo o rol trazido pela lei, diz que devem ser analisadas as condições sociais dos pais. Assim, havendo possibilidade, poderia incluir nesse quantum despesas com hidroginástica, Yoga. Segundo a autora, apesar de serem despesas que não são indispensáveis, tais despesas contribuem com uma boa gestação. Acerca disso, concluo que observado o binômio possibilidade-necessidade poderia ser deferido tais alimentos porque, apesar de não serem indispensáveis, indiretamente contribuem para o objetivo da lei (promover uma gestação sadia).

No capitulo III, ao tratar do quantum devido, fora dito que Cícero Goulart de Assis entende que os alimentos gravídicos deveriam cobrir despesas indispensáveis avalizadas por médico ou juiz. Assim, não estaria dentro do rol exames de ultra-som meramente feitos para definir a aparência do feto, destinados somente a vaidade da mãe.

Portanto, apesar do rol não ser exaustivo, há um limite a essa extensão feita por Ana Maria Louzada e Marklea Da Cunha Ferst com base na condição social. Assim, gastos que não contribuem nem direta e nem indiretamente para a sadia gestação não podem ser considerados. Quanto a gastos indispensáveis imediatamente após o nascimento - ex.: vestuário do bebê - também estariam inclusos no rol por força do art.6º parágrafo único da Lei 11.804/2008. Em todos 
esses casos, é preciso atentar para o fato de que a mulher também deve contribuir com as despesas que serão custeadas na proporção dos recursos de ambos.

É preciso ter em mente que, embora a lei proponha a conversão dos alimentos gravídicos em alimentos propriamente ditos, os mesmos não se confundem. Os alimentos propriamente ditos são alimentos legítimos concedidos em razão do parentesco (ou conforme explicado, em razão do dever de sustento se o filho for menor). Ao revés, os alimentos gravídicos, embora esteja próximo dos alimentos legítimos devido à possibilidade de haver algum parentesco, não são de fato legítimos. Isso ocorre porque, conforme dito no capitulo III, o deferimento de alimentos gravídicos é feito com base em meros indícios de paternidade e sua sentença não faz coisa julgada quanto a essa relação. Assim, após o nascimento, caso haja prova negativa da paternidade, a obrigação pode ser desconstituída.

Outro ponto interessante da lei seria a questão da conversão dos alimentos gravídicos em pensão alimentícia. Nesse ponto, parece que o legislador partiu da premissa que após o nascimento da criança as partes irão solicitar a revisão da pensão. Afinal, o legislador faz uma conversão entre institutos que não se confundem. Explique-se:

Os alimentos gravídicos são deferidos com base em indícios de paternidade. Os alimentos legítimos possuem como fundamento o parentesco, ou seja, para se tornarem definitivos é preciso a constituição do vínculo. A sentença que defere os alimentos gravídicos não é apta a criar esse vínculo de paternidade. A paternidade deve ser atestada após o nascimento da criança. Assim, o caminho natural imaginado pelo legislador seria que após o nascimento da criança as partes tomassem medidas para atestar a paternidade ou não.

Todavia, o legislador não fez qualquer menção ao que acontece se as partes não procederem desta forma. Tendo em vista que os institutos são inconfundíveis, para resolver a questão e contornar a situação Maria Berenice Dias sugere a expedição de mandado de registro, independentemente de ter sido buscado o reconhecimento da paternidade, capaz de dispensar a propositura da ação investigatória de paternidade para o estabelecimento do vínculo. De fato, é 
uma idéia, mas é preciso aguardar a jurisprudência se pronunciar quanto a essa omissão do legislador.

Por fim, o último ponto que merece destaque seria o veto do art.10 que previa a responsabilização da gestante em caso de negativa de paternidade após o nascimento. Acertado foi o veto deste dispositivo, uma vez que dificultaria o acesso à justiça tornando sem grande aplicação a lei. Afinal, o artigo previa a responsabilidade objetiva da gestante. Logo, somente pleiteariam tais alimentos aquelas mulheres que possuíssem absoluta certeza daquela paternidade.

Sendo certo que os alimentos são irrepetíveis, caso ao final do exame de DNA seja comprovado que o suposto pai não era de fato o pai, não poderá pedir a restituição do valor dos alimentos. Todavia, apesar do veto do art.10 da lei, poderia o suposto pai, nesse caso, se valer da responsabilidade subjetiva (art.186 $\mathrm{CC}$ ), se fosse o caso, para ingressar com ação de responsabilidade contra a genitora. Desta forma, por se tratar de responsabilidade subjetiva, deveria provar além do nexo de causalidade, que a gestante agiu com culpa.

Em suma, é possível concluir que a lei sem dúvida foi muito importante para alterar a jurisprudência dominante e garantir de fato o direito dos nascituros aos alimentos, mas apresenta alguns pontos para serem desenvolvidos pela jurisprudência como, por exemplo, definir o que seriam indícios de paternidade, a amplitude do quantum e a questão da conversão dos alimentos gravídicos. 


\section{BIBLIOGRAFIA}

GONÇALVES, Carlos Roberto. Direito Civil Brasileiro: Direito de Família, v. 6. $6^{a}$ ed. rev. e atual. - São Paulo: Saraiva, 2009. 667 p.

PEREIRA, Caio Mario da Silva. Instituições de direito Civil: Direito de Família, v.5. $16^{\mathrm{a}}$ ed. rev. e atual. - Rio de Janeiro: Forense, 2007. 585 p.

DIDIER JR., Fredie; CUNHA, Leonardo José Carneiro da; BRAGA, Paula Sarno; OLIVEIRA, Rafael. Curso de direito Processual Civil: Execução. vol. 5. $2^{a}$ ed., Jus Podivm, 2010. 800 p.

LOUZADA, Ana Maria Gonçalves. Alimentos: Doutrina e Jurisprudência. Belo Horizonte: Del Rey, 2008. 261 p.

DIAS, Maria Berenice. Conversando sobre Alimentos. Porto Alegre: Livraria do Advogado Ed., 2006. 129 p.

MADALENO, Rolf. Obrigação, dever de assistência e alimentos transitórios. $2004 . \quad$ Disponível em: http://www2.cjf.jus.br/ojs2/index.php/cej/article/viewFile/636/816. Acesso em: 15.04.11.

GONÇALVES, Carlos Roberto. Direito Civil Brasileiro: Parte Geral, v.1. $7^{\mathrm{a}}$ Ed. rev. e atual. - São Paulo: Saraiva, 2009. 518 p.

PEREIRA, Caio Mario da Silva. Instituições de direito Civil: Introdução do direito Civil. Teoria Geral de Direito Civil, v.1. 20a ed. rev. e atual. - Rio de Janeiro: Forense, 2004. 718 p.

FILHO, José Roberto Moreira. O direito Civil em face das novas técnicas de reprodução assistida. Jus Navigandi, Teresina, ano7, n. 55, 1 mar. 2002. Disponível em: http://jus.uol.br/revista/texto/2747 Acesso em: 29 abr.2011.

EVANGELISTA, Anderson. Feto tem direito a pensão alimentícia. In: Âmbito Jurídico, Rio Grande, 53, 31/05/2008. Disponível em: http://www.ambitojuridico.com.br/site/index.php?n_link=revista_artigos_leitura\&artigo_id=2841 Acesso em: 29 abr. 2011.

SANTOS, Marina Alice de Souza. Da titularidade dos alimentos gravídicos: uma (re) visão das teorias do inicio da personalidade. IBDFAM. 30 mar. 2010. Disponível em: http://www.ibdfam.org.br/?artigos\&artigo=599 Acesso em: 2 abr. 2011.

CHAVES, João Freitas de Castro. Responsabilidade civil por dano causado ao nascituro: possibilidades de reparação no direito brasileiro. Jus Navigandi, 
Teresina, ano 5, n. 46, 1 out. 2000. Disponível em: <http://jus.uol.com.br/revista/texto/524>. Acesso em: 29 abr. 2011.

FILHO, José Roberto Moreira. O direito Civil em face das novas técnicas de reprodução assistida. Jus Navigandi, Teresina, ano7, n. 55, 1 mar. 2002. Disponível em: http://jus.uol.br/revista/texto/2747 Acesso em: 29.04.11.

LOMEU, Leandro Soares. Alimentos Gravídicos: aspectos da lei 11.804/08. IBDFAM. 19 nov. $2008 . \quad$ Disponível em: http://www.ibdfam.org.br/?artigos\&artigo=467 Acesso em: 29 abr. 2011.

GÓES, Jamille Argolo. Direito do nascituro a alimentos. Uma abordagem civilconstitucional. Jus Navigandi, Teresina, ano 15, n.2442, 9 mar. 2010. Disponível em: http://jus.uol.com.br/revista/texto/14464 Acesso em: 11 mar. 2011.

FERST, Marklea da Cunha. Direito na prática: Alimentos e ação de alimentos. Manual do operador do direito. $1^{\text {a }}$ Ed (ano 2009), $2^{\text {a }}$ reimp. Curitba: Juruá, 2011. $171 \mathrm{p}$.

DIAS, Maria Berenice. Alimentos Gravídicos?. Jus Navigandi, Teresina, ano 13, n.1853, 28 jul. 2008. Disponível em: http://jus.uol.com.br/revista/texto/11540 Acesso: 9 mar. 2011.

AI n ${ }^{\circ}$ 70006429096, Sétima Câmara Cível, Tribunal de Justiça do RS, Relator: Sérgio Fernando de Vasconcellos Chaves, Julgado em 13/08/2003, citado no artigo $O$ Ministério Público e sua atuação em face dos alimentos gravídicos, encontrado no http://www.ampep.com.br/novo/gravdicos.doc acesso: 30. abr.2011.

TJMG, Processo $\mathrm{n}^{\mathrm{o}}$. 1.0024.04.377309-2/001(1), Rel. Duarte de Paula, j. 10.03.05, publicação 10.06.05, citado no artigo $O$ Ministério Público e sua atuação em face dos alimentos gravídicos, encontrado no http://www.ampep.com.br/novo/gravdicos.doc acesso: 30. abr.2011.

TJRS, Agravo de instrumento n. 70018406652, Rel. Des. Maria Berenice Dias, DJ. 16.04.2007, citado no artigo O Ministério Público e sua atuação em face dos alimentos gravídicos, encontrado no http://www.ampep.com.br/novo/gravdicos.doc acesso: 30 abr. 2011.

ROSA, Rita de Cássia Peres da. Alimentos Gravídicos, análise constitucional, obrigacional e processual. Conteúdo jurídico, Brasília-DF: 18 mar. 2010. Disponível em: http://www.conteúdojurídico.com.br/?artigos\&ver=2.263319 acesso em: 11 mar. 2011.

GONÇALVES, Carlos Roberto. Direito Civil Brasileiro: Direito de Família, v. 6. $8^{\mathrm{a}}$ Ed. rev. e atual. - São Paulo: Saraiva, 2011. 728 p. 
BARROS, Flávio Monteiro de. Alimentos Gravídicos. Curso FMB. Disponível: http://www.cursofmb.com.br/cursofmbjuridico/artigos/download.php?file=ALIM ENTOS\%20GRAV\%CDDICOS.pdf Acesso em: 06 mai. 2011.

DANOSO, Denis. Alimentos Gravídicos. Aspectos Materiais e processuais da Lei $n^{\circ}$ 11.804/2008. Jus Navigandi, Teresina, ano 14, n.2028, 19 jan. 2009. Disponível em: http://jus.uol.com.br/revista/texto/12219 Acesso em: 11 mar. 2011.

TJDF. Apelação Cível 20090810061229. $1^{\mathrm{a}}$ Turma Cível. Relatora: Desembargadora Vera Andrighi. Acórdão $n^{\circ}$ 407.126, Brasília (DF), 13 de jan. 2010 . Disponível em: http://www.jusbrasil.com.br/jurisprudencia/8179627/apelacao-ci-vel-apl61222420098070008-df-0006122-2420098070008-tjdf

SIMÕES, Thiago Felipe Vargas. Breves linhas sobre os alimentos gravídicos. In: Âmbito Jurídico, Rio Grande, 77, 01/06/2010 [Internet]. Disponível em: http://www.ambitojuridico.com.br/site/index.php?n_link=revista_artigos_leitura\&artigo_id=7562 Acesso em 06 mai. 2011.

TJRJ. Agravo de Instrumento 220333320108190000. 9ª Câmara Cível. Relator: Desembargador Marco Aurélio Froes. 14 de set. 2010. Disponível em: http://www.jusbrasil.com.br/jurisprudencia/17046293/agravo-de-instrumento-ai220333320108190000-rj-0022033-3320108190000-tjrj

ASSIS, Cícero Goulart de. Questões Polêmicas dos Alimentos Gravídicos. Disponível

em: http://www.r2learning.com.br/_site/artigos/artigo_default.asp?ID=1503 Acesso em: 11 mar. 2011.

TJMG. Agravo de Instrumento ${ }^{\circ}$ 1.0210.09.061222-2/001 - Comarca de Pedro Leopoldo - Relator: Alberto Vilas Boas. 15 jun. 2010. Disponível em: http://www.tjmg.jus.br/juridico/jt_/inteiro_teor.jsp?tipoTribunal=1\&comrCodigo $=210 \&$ ano $=9 \&$ txt_processo $=61222 \&$ complemento $=1 \&$ sequencial $=0 \&$ palavrasC onsulta=ALIMENTOS\%20GRAVÍDICOS\&todas=\&expressao=\&qualquer=\&se $\mathrm{m}=\&$ radical $=$ Acesso em: 16 mai. 2011.

TJSP. Apelação Cível n ${ }^{\circ}$ 990.10.168.926-0. Voto $n^{\circ}$ 14.028. 4ª Câmara de direito Privado do Tribunal de Justiça de São Paulo. Relator: Natan Zelinschi de Arruda. 5 ago. $2010 . \quad$ Disponível em: http://www.jusbrasil.com.br/filedown/dev1/files/JUS2/TJSP/IT/APL_990101689 260_SP_1282148313905.pdf Acesso em: 16 mai. 2011.

TJDF. Apelação Cível 20100111558842APC. 2 $2^{\mathrm{a}}$ Turma Cível. Relatora: Desembargadora CARMELITA BRASIL. 13 abr. 2011. Disponível em: 
http://www.jusbrasil.com.br/filedown/dev5/files/JUS2/TJDF/IT/APL_507404120 108070001_DF_1302919039963.doc Acesso em: 17 mai. 2011.

TJRS. Agravo de Instrumento $n^{\circ} 70033946393$ - Comarca de Caxias do Sul. $7^{\text {a }}$ Câmara Cível - Relator: Des, André Luiz Planella Villarinho. 20 dez. 2009. Disponível em: http://www.jusbrasil.com.br/filedown/dev5/files/JUS2/TJRS/IT/AI_7003394639 3_RS_1289827969901.doc Acesso em: 16 mai. 2011.

TJDF. Agravo de Instrumento 20090020086696AGI. 1 ${ }^{a}$ Turma Cível. Relatora: Desembargadora MARIA DE FÁTIMA RAFAEL DE AGUIAR RAMOS. 28 out. 2009. Disponível em: http://www.jusbrasil.com.br/filedown/dev2/files/JUS2/TJDF/IT/AI_8669612009 8070000_DF_1259878884404.doc Acesso em: 17 mai. 2011

Mensagem $n^{\circ}$ 853. Presidente da República. Casa Civil. Subchefia para assuntos jurídicos. Disponível em: http://www.planalto.gov.br/ccivil_03/_ato20072010/2008/Msg/VEP-853-08.htm Acesso em: 16 mai. 2011

FREITAS, Douglas Phillips, Alimentos Gravídicos e a Lei 11.804/2008 Primeiros Reflexos. Disponível em: www.ibdfam.org.br/?artigos\&artigo=468 Acesso em: 16 mai. 2011

TJSP. Agravo de Instrumento $n^{\circ}$ 994.09.290371-9. Comarca de Campo Limpo Paulista/ Jundiaí. $4^{\mathrm{a}}$ Câm. De Direito Privado. Relator: Ênio Santarelli Zuliani. 13. jan. 2010. Disponível em: http://www.jusbrasil.com.br/filedown/dev1/files/JUS2/TJSP/IT/AI_99409290371 9_SP_1265401874813.pdf Acesso em: 16 mai. 2011

TJDF. Agravo de Instrumento 20090020119831. 5 ${ }^{\text {a }}$ Turma Cível. Relator: Desembargador Lecir Manoel da Luz. 11 nov. 2009 Disponível em: http://www.jusbrasil.com.br/filedown/dev2/files/JUS2/TJDF/IT/AI_1198315200 98070000_DF_1259873093591.doc Acesso em: 17 mai. 2011

TJDF. Agravo de Instrumento n ${ }^{\circ}$ 20090020149469. 1 ${ }^{a}$ Turma Cível. Relatora: Desembargadora Vera Andrighi. 16 dez. 2009. Disponível em: http://www.jusbrasil.com.br/filedown/dev2/files/JUS2/TJDF/IT/AI_1494693200 98070000_DF_1267043302045.doc Acesso em: 16 mai 2011

TJSC. AI n 2010.029905-5, de Blumenau. 2ª Câmara de Direito Cível. Relator: Jaime Luiz Vicari. 14 set. 2010. Disponível em: http://www.jusbrasil.com.br/filedown/dev5/files/JUS2/TJSC/IT/AI_299055_SC_ 1300111661783.doc Acesso em: 16 mai. 2011

TJMG. AI $\mathrm{n}^{\circ}$ 102100906122220011. $2^{\mathrm{a}}$ Vara Cível da Comarca de Pedro Leopoldo. Relator: Desembargador Alberto Vilas Boas. 02 out. 2009. Disponível 
em: http://www.jusbrasil.com.br/jurisprudencia/6025315/102100906122220011mg-1021009061222-2-001-1-tjmg Acesso em: 16 mai. 2011

TJPR. AI n ${ }^{\circ}$ 606413-3. $2^{\mathrm{a}}$ Vara de Família do Foro Central da Comarca da Região Metropolitana de Curitiba. Relator: Antonio Domingos Ramina Junior. 25 nov. 2009 Disponível em: http://www.jusbrasil.com.br/jurisprudencia/6083020/agravo-de-instrumento-ai6064133-pr-0606413-3-tjpr/inteiro-teor Acesso em: 16 mai. 2011

TJPR. AI $\mathrm{n}^{\circ}$ 595.601-4, da Comarca de Cianorte. Vara da Infância e da Juventude e Anexos. Relator: Luiz Antonio Barry. 18 nov. 2009. Disponível em: http://www.jusbrasil.com.br/jurisprudencia/6127433/agravo-de-instrumento-ai5956014-pr-0595601-4-tjpr/inteiro-teor Acesso em: 16 mai. 2011

TJSP. AI n ${ }^{\circ} .990 .10 .204511-0$, da Comarca de Jundiaí. 6a Câmara de Direito Privado. Relator: Vito Guglielmi. 5 ago. 2010. Disponível em: http://www.jusbrasil.com.br/jurisprudencia/15824111/agravo-de-instrumento-ai990102045110-sp-tjsp Acesso em: 16 mai. 2011

TJSP. AI n ${ }^{\circ}$ 990.10.440913-6, da Comarca de São Paulo. 10ª Câmara de Direito Privado. Relator: Testa Marchi. 23 nov. 2010. Disponível em: http://www.jusbrasil.com.br/filedown/dev1/files/JUS2/TJSP/IT/_4409131320108 260000_SP_1294078877620.pdf Acesso em: 16 mai. 2011

TJMG. Apelação Cível n ${ }^{\circ}$ 1.0702.08.501783-9/001, Comarca de Uberlândia. $4^{a}$ Câmara Cível. Relator: Dárcio Lopardi Mendes. 26 mar. 2009. Disponível em: http://www.jusbrasil.com.br/jurisprudencia/5990151/107020850178390011-mg1070208501783-9-001-1-tjmg/inteiro-teor Acesso em: 16 mai. 2011 


\author{
Presidência da República \\ Casa Civil \\ Subchefia para Assuntos Jurídicos
}

\title{
LEI N ${ }^{\circ} 11.804$, DE 5 DE NOVEMBRO DE 2008.
}

Mensagem de Veto

Disciplina o direito a alimentos gravídicos e a forma como ele será exercido e dá outras providências.

O PRESIDENTE DA REPÚBLICA Faço saber que o Congresso Nacional decreta e eu sanciono a seguinte Lei:

Art. 1ㅜㅡㄹ Esta Lei disciplina o direito de alimentos da mulher gestante e a forma como será exercido.

Art. 2⿳⺈ Os alimentos de que trata esta Lei compreenderão os valores suficientes para cobrir as despesas adicionais do período de gravidez e que sejam dela decorrentes, da concepção ao parto, inclusive as referentes a alimentação especial, assistência médica e psicológica, exames complementares, internações, parto, medicamentos e demais prescrições preventivas e terapêuticas indispensáveis, a juízo do médico, além de outras que o juiz considere pertinentes.

Parágrafo único. Os alimentos de que trata este artigo referem-se à parte das despesas que deverá ser custeada pelo futuro pai, considerando-se a contribuição que também deverá ser dada pela mulher grávida, na proporção dos recursos de ambos.

Art. $3^{\circ}$ (VETADO)

Art. $4^{\circ}(\mathrm{VETADO})$

Art. $5^{\circ}$ (VETADO)

Art. 6 $^{\mathbf{0}}$ Convencido da existência de indícios da paternidade, o juiz fixará alimentos gravídicos que perdurarão até o nascimento da criança, sopesando as necessidades da parte autora e as possibilidades da parte ré.

Parágrafo único. Após o nascimento com vida, os alimentos gravídicos ficam convertidos em pensão alimentícia em favor do menor até que uma das partes solicite a sua revisão.

Art. $7^{\mathbf{0}}$ O réu será citado para apresentar resposta em 5 (cinco) dias.

Art. $8^{\circ}$ (VETADO)

Art. $9^{\circ}(\mathrm{VETADO})$

Art. $10^{\circ}$ (VETADO)

Art. 11. Aplicam-se supletivamente nos processos regulados por esta Lei as disposições das Leis n ${ }^{\text {os }} 5.478$, de 25 de julho de 1968, e 5.869, de 11 de janeiro de 1973 - Código de Processo Civil.

Art. 12. Esta Lei entra em vigor na data de sua publicação.

Brasília, 5 de novembro de $2008 ; 187^{\circ}$ da Independência e $120^{\circ}$ da República.

LUIZ INÁCIO LULA

Tarso

José Antonio $\quad$ Dias $\quad$ Toffoli

José Antonio $\quad$ Dias $\quad$ Toffoli

Genro

Dilma Rousseff

Este texto não substitui o publicado no DOU de 6.11.2008 
ANEXO II 